Florida International University FIU Digital Commons

\title{
La caída del hombre nuevo : narrativa Cubana del período especial
}

Sonia Behar

Florida International University

DOI: $10.25148 /$ etd.FI14050472

Follow this and additional works at: https://digitalcommons.fiu.edu/etd

Part of the Spanish and Portuguese Language and Literature Commons

\section{Recommended Citation}

Behar, Sonia, "La caída del hombre nuevo : narrativa Cubana del período especial" (2007). FIU Electronic Theses and Dissertations. 1462.

https://digitalcommons.fiu.edu/etd/1462 


\section{FLORIDA INTERNATIONAL UNIVERSITY}

Miami, Florida

LA CAÍDA DEL HOMBRE NUEVO:

NARRATIVA CUBANA DEL PERÍODO ESPECIAL

A dissertation submitted in partial fulfillment of the

requirements for the degree of

DOCTOR OF PHILOSOPHY

in

SPANISH

by

Sonia Behar

2007 
This dissertation, written by Sonia Behar, and entitled La caída del Hombre Nuevo:

Narrativa cubana del Periodo Especial, having been approved in respect to style and intellectual content, is referred to you for judgment.

We have read this dissertation and recommend that it be approved.

Erik Camayd-Freixas

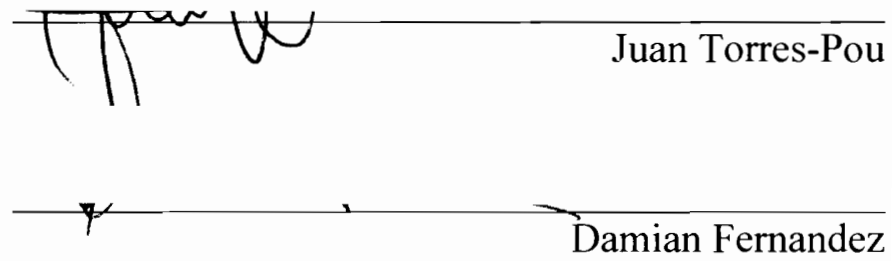

Ricardo Castells, Major Professor

Date of Defense: March 30, 2007

The dissertation of Sonia Behar is approved.

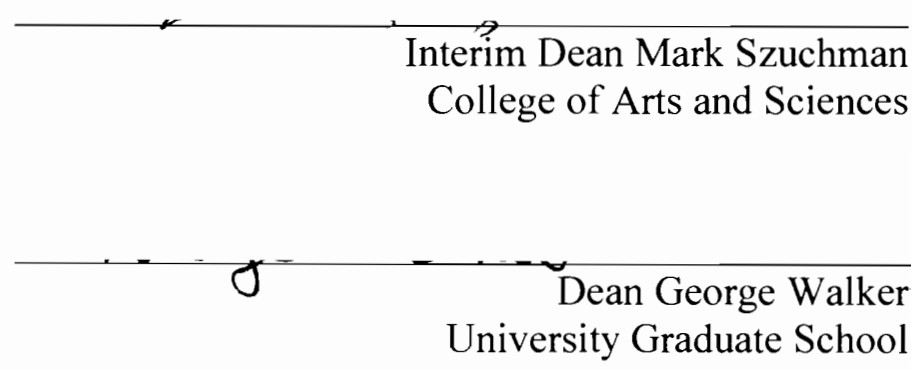

Florida International University, 2007 
(C) Copyright 2007 by Sonia Behar All rights reserved. 


\section{DEDICATION}

I dedicate this dissertation to my aunt Sonia whose memory has been my most valuable source of inspiration. 


\section{ACKNOWLEDGMENTS}

I wish to thank the members of my committee, Dr. Ricardo Castells, Dr. Erik Camayd-Freixas, Dr. Juan Torres-Pou, and Dr. Damian Fernandez, for their support and wise suggestions, and for sharing their vast knowledge with me beyond the classroom. I appreciate the faith they had in my ability to complete this project. At times their confidence proved to be greater than mine. Two years ago, Dr. Castells, my Major Professor, told me: "I am sure that you can do this." Now I believe it.

I also would like to thank all my professors and fellow graduate students in the Department of Modern Languages for their interest in my work, and for allowing me to share with them my experience during the writing of this dissertation.

Finally, I am most grateful to my family, for never doubting me. To the ones I said goodbye to more than twenty years ago, thank you for being there to remind me who I am and where I come from. I shall never forget you. 


\title{
ABSTRACT OF THE DISSERTATION \\ LA CAÍDA DEL HOMBRE NUEVO: \\ NARRATIVA CUBANA DEL PERÍODO ESPECIAL \\ by
}

Sonia Behar

Florida International University, 2007

\author{
Miami, Florida \\ Professor Ricardo Castells, Major Professor
}

The purpose of this dissertation is to demonstrate that the societal changes that took place in Cuba during the last decade of the twentieth century, period know as The Special Period in Times of Peace, created the necessary conditions for the development of a new type of narrative. The first chapter constitutes an historical overview of the role of the State in the literary and artistic creation in revolutionary Cuba. The second, third, and fourth chapters analyze the major characteristics in the narrative of this period, creating a contrast with previous decades of the revolutionary era. With such purpose the study is divided into three categories: language, themes, and ideology. The usage of language as a means of transgression, the recurrence of the topic of need, and the rebirth of critical thinking, represent the principal characteristics of this literary period, and confirm the main idea of this dissertation: the fall of the ideal of the New Man. The final chapter summarizes the findings of the study and poses a question: If the ideal of the New Man has ceased to exist, what has replaced it? The question of whether or not a new ideal has replaced that of the New Man, and what that ideal might be, constitutes a steppingstone for further studies in the area of Cuban narrative of the Special Period and beyond. 


\section{ÍNDICE}

CAPÍTULO

PÁGINA

I. REVOLUCIÓN, SOCIEDAD Y CULTURA: LA TRAYECTORIA REVOLUCIONARIA FRENTE A LA EXPRESIÓN ARTÍSTICOLITERARIA CUBANA

Una nueva era: El triunfo de la revolución y la década de los sesenta .1

La década de los setenta: Redefinición de la relación creador-Estado.............16

La década de los ochenta: Gestación del pensamiento crítico y de la experimentación literaria

El Período Especial en Tiempos de Paz: El surgimiento de una nueva literatura.

II. NUEVAS FORMAS DE EXPRESIÓN EN LA NARRATIVA DEL PERÍODO ESPECIAL: IMAGEN Y VOZ DEL ENTORNO.........................46

Manifestaciones tremendistas en El Rey de La Habana a partir de La familia de Pascual Duarte.

Realismo sucio cubano: Rasgos del Dirty Realism norteamericano

En los cuentos de Pedro Juan Gutiérrez, Ángel Santiesteban y Jorge Alberto Aguiar Díaz.

III. LAS TEMÁTICAS EN LA NARRATIVA CUBANA DEL PERÍODO ESPECIAL. HAMBRE, EXILIO Y NOSTALGIA: HACIA UNA CONCEPTUACIÓN DE LA CARENCIA

El hambre: Ausencia y búsqueda en El hombre, la hembra y el hambre .93

Distancia y lejanía: La nostalgia del exilio y del insilio.

IV. RESURGIMIENTO DEL PENSAMIENTO CRÍTICO EN LA NARRATIVA DEL PERÍODO ESPECIAL.

La novela de mi vida: Función del perspectivismo y la ficción

en el cuestionamiento de la historia oficial

Jesús Díaz y Abel Prieto: Hacia una re-visión

del proyecto revolucionario

CONCLUSIONES

BIBLIOGRAFÍA 201

VITA. 


\section{Capítulo I}

Revolución, sociedad y cultura:

La trayectoria revolucionaria frente a la expresión artístico-literaria cubana

\section{Una nueva era: EI triunfo de la revolución y la década de los sesenta}

La isla de Cuba despierta a una nueva era el primero de enero de 1959, con el triunfo del ejército rebelde bajo el liderazgo de Fidel Castro Ruz y el derrocamiento del gobierno de Fulgencio Batista. Es el comienzo de una etapa que cambiaría el destino de la nación en diversos sentidos. Como ha notado Edmundo Desnoes, "La revolución comenzó con la fuerza de un huracán, con la ambición y el dinamismo de una dirección política joven, empeñada en construir un socialismo justo y radical, decidida honestamente a encontrar un camino propio, preocupada por evitar los errores del sistema socialista oficial existente" (Epílogo 534). A su vez, Antón Arrufat describe los comienzos del proceso revolucionario, cuando regresa a Cuba en el año 1959, como "una especie de alegría generalizada". Arrufat cuenta que "[e]n aquella época, se gobernaba por televisión, y la gente se sentaba en sus hogares a ver y a oír los cambios futuros [ . . ] El pueblo entraba en las milicias, y se hacían prácticas de tiro. Todo el poder que se puede pensar en un país estaba de nuestra parte y uno lo ejerció alegre e irresponsablemente" (cit. en Kirk 70).

La revolución, según Ernesto Guevara, significa para la gran mayoría, revolucionarios o no, un nuevo camino a seguir. Pero también se produce el éxodo masivo de los "domesticados totales" (12). No obstante, el éxodo masivo de los susodichos domesticados no representa un problema para el proceso revolucionario, según el argumento de Guevara. Una de las grandes dificultades que enfrenta la 
revolución es, desde la perspectiva guevariana, que aun entre los revolucionarios, sobre todo entre los intelectuales, se mantienen vestigios del idealismo burgués en sus conciencias (12). Para Guevara, la revolución es como un proceso de construcción del socialismo donde se perfila el nacimiento del Hombre Nuevo, cuya imagen "no está todavía acabada" y que "no podría estarlo nunca ya que el proceso marcha paralelo al desarrollo de formas económicas nuevas" (8). El 16 de abril de 1961, durante el sepelio de las víctimas de los bombardeos aéreos durante la invasión a Playa Girón, Fidel Castro presenta una definición concreta de la revolución cuando dice: "Compañeros obreros y campesinos: esta es la Revolución socialista y democrática de los humildes, por los humildes y para los humildes. Y por esta Revolución [. . .] estamos dispuestos a dar la vida" (cit. en García Luis 68).

Entre los numerosos cambios que trae consigo la revolución cubana está el efecto que produce en el desarrollo de las artes, ya que éstas pasan a jugar un nuevo papel dentro de la nueva sociedad que comienza a perfilarse desde muy temprano en el proceso revolucionario cubano. Los cambios que se suscitan en el ámbito literario en los primeros años de la revolución se presentan detalladamente en el estudio de Seymour Menton, $L a$ narrativa de la Revolución cubana (1975), el cual ofrece un panorama de la trayectoria narrativa desde el año 1959 hasta 1971. La recopilación de Menton, que en muchos aspectos coincide con la de Lourdes Casal, hace notar un dramático descenso en el número de novelas publicadas en Cuba a partir de la política oficial anunciada por el gobierno en 1968 e impuesta en 1971. Las novelas que continúan produciéndose y publicándose en la isla dan, según Ángel Rama, un giro que abandona la línea de lo maravilloso y se centra en una narrativa documental, realista y programática (201). El 
acierto de un enfoque cronológico como el de Seymour Menton, explica Eduardo C. Béjar, radica en que "propicia una caracterización de la actitud y estrategias asumidas por los escritores cubanos, sincronizadas con el desarrollo de las diferentes etapas del ideario político-revolucionario" (17).

Menton propone un primer momento que va de 1959 a 1961, período en que el tema recurrente de las obras producidas es la lucha contra la tiranía de Fulgencio Batista. Se trata de una época de gran furor y entusiasmo patriótico, donde reina la espontaneidad y una gran desorientación tanto por parte del gobierno como por parte de los escritores. La insurrección contra la dictadura batistiana y la persecución contra los conspiradores son sucesos centrales de las obras escritas durante estos años. Algunas de las novelas representativas de este período son El sol a plomo de Humberto Arenal (1959), Bertillón 166 de José Soler Puig (1960) y Mañana es 26 de Hilda Perera Soto (1960).

El segundo ciclo abarca de 1961 a 1965 . Menton subraya que en este ciclo la temática que subyace es la existencial, causada posiblemente por una prolongada visita de Jean Paul Sartre a Cuba, y quizás porque a los autores existencialistas ya se les leía en Cuba desde la década de los cincuenta. En las novelas de este período se observa, según Menton, la angustia y la alienación del ser humano en la sociedad contemporánea, en especial la culpabilidad que experimentan muchos escritores por su pasado burgués. Como afirma Edmundo Desnoes, numerosos escritores se sienten "marcados por el 'pecado original' de haberse formado antes de la revolución y dentro de la concepción del artista como conciencia de la sociedad" (xx). Conjuntamente con el sentimiento de culpa se presenta como tema en la obra literaria de estos escritores cierta indiferencia hacia la realidad revolucionaria, "la cual tratan de exorcizar a través de sus relatos" (Béjar 18). 
Entre las tendencias básicas de este período se encuentra la autocensura autorial, ya que los escritores tratan de evitar temas polémicos por temor a que éstos fuesen tildados de contrarrevolucionarios. Esta actitud de autocensura se debe principalmente al discurso pronunciado por Fidel Castro a raíz de la invasión a Playa Girón, y otros que subsiguen durante 1961, en los que finalmente se establece una actitud definitiva del gobierno ante los parámetros de la creación. La política delimitante que asume el gobierno frente a la creación literaria continúa recrudeciéndose hasta que alcanza su máximo rigor en 1971, con el renombrado caso de Heberto Padilla.

Las novelas que se publican en este segundo lapso pertenecen, a su vez, a subgrupos diferentes. Por una parte, está el tema de la enajenación, la soledad y la angustia, elementos típicos del héroe existencial (antiguo burgués). Entre las obras de este subgrupo se encuentra No hay problema de Edmundo Desnoes (1961). En otra vertiente se observa un interés por revelar la decadencia social del período prerrevolucionario, con novelas que incorporan técnicas narrativas más avanzadas como el monólogo interior, la mezcla de períodos históricos y la alternación de puntos de vista narrativos. En esta categoría se sitúan Memorias del subdesarrollo de Edmundo Desnoes (1965) y En el año de enero de José Soler Puig (1963). Menton hace referencia a otro sub-grupo en el que se repite el contraste entre las sociedades pre y posrevolucionarias, pero en un ambiente

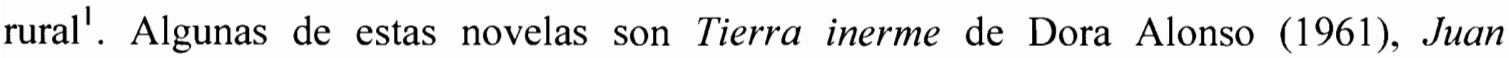
Quinquín en Pueblo Mocho de Samuel Feijoo (1963) y Tabaco de Leonel López-Nussa (1963).

\footnotetext{
${ }^{1}$ Menton observa el escaso número de "novelas de la tierra" publicadas desde el comienzo de la revolución, hecho que considera irónico, teniendo en cuenta que precisamente la reforma agraria fue uno de los principales objetivos revolucionarios.
} 
Menton cataloga el tercer período (1966-1970) de "Epos, experimentación y escapismo" (48). Durante este período la producción novelística del país experimenta un grado de realización sin precedentes en la historia de la narrativa cubana. Se produce, como afirma Menton, cierto relajamiento en la postura oficial como consecuencia del intento de independencia con relación a la influencia política soviética. El gobierno se desvía del modelo convencional soviético, alegando que con el enfoque idealista Cuba ha logrado aventajar a la URSS. Como resultado del nuevo enfoque, surge una situación de tensión entre los dos países, hasta el punto que en 1967 se reduce el suministro soviético a la isla (Mesa-Lago 24).

La característica que predomina en la producción novelística de este período es el uso experimental de técnicas más a tono con las nuevas tendencias de la novela hispanoamericana. La temática se enriquece igualmente con elementos épicos, míticos y fantásticos. Los elementos anteriormente mencionados son evidentes en novelas como Paradiso de José Lezama Lima (1966), Pasión de Urbino de Lisandro Otero (1966), Tres tristes tigres de Guillermo Cabrera Infante (1967), De donde son los cantantes de Severo Sarduy (1967) y Biografia de un cimarrón de Miguel Barnet (1968). Precisamente durante estos años (1966-1970) se produce en Cuba lo que Carmelo Mesa-Lago considera uno de los ciclos idealistas por los que ha atravesado el proceso revolucionario en numerosas ocasiones ${ }^{2}$. Éste, afirma Mesa-Lago, es el ciclo idealista más fuerte, y lo llama “Adopción y Radicalización por Castro del Modelo Guevarista” (17). Durante este ciclo, la política del gobierno se centra en aspectos colectivistas, haciendo hincapié en el

\footnotetext{
${ }^{2}$ Mesa-Lago establece un contraste entre los ciclos idealistas (con metas poco realistas como fabricar diez millones de toneladas de azúcar) y ciclos pragmáticos (donde se hacen mejoras moderadas en la economía).
} 
trabajo voluntario y las movilizaciones laborales, los cuales responden a la insistencia de Guevara en la necesidad de "elegir correctamente el instrumento de movilización de las masas" (7). El objetivo de las actividades en masa, como la campaña de alfabetización, es enfocar la atención en ideales colectivistas adoptados por los líderes de la revolución, como el igualitarismo, la reducción de diferencias salariales, el énfasis en los incentivos morales en lugar de los materiales, y la expansión de los servicios sociales gratuitos. Con las nuevas medidas, el gobierno aspira a forjar el Hombre Nuevo socialista (25).

Con la muerte de Guevara en 1967, el Hombre Nuevo se convierte en un ideal que, entre otras cosas, rinde homenaje al hombre ahora considerado como un héroe muerto en el campo de batalla en su lucha por diseminar el comunismo en América Latina. La revolución continúa siendo, de una forma u otra, el elemento de inspiración para la creación. Edmundo Desnoes sugiere, por ejemplo, que la revolución es el generador incluso de Paradiso de José Lezama Lima, ya que toda la novela está "teñida por la óptica de la nueva sociedad" (xviii). Se exceptúa el capítulo VIII de la novela, ya que, como dice Desnoes, éste recibe numerosas objeciones oficiales antes de su publicación, objeciones que reflejan el puritanismo de cierto sector de la dirigencia revolucionaria frente al grotesco, descarnado e irreverente erotismo del adolescente Farraluque. A pesar de tales objeciones, o tal vez precisamente a causa de ellas, este capítulo tiene "la dudosa virtud de haber sido el único capítulo que devoró con curiosidad enfermiza la mayoría de los lectores cubanos" (xviii).

Mientras que las etapas de la trayectoria de la narrativa de la revolución cubana previamente comentadas establecen una estrecha relación entre la evolución sociopolítica que comienza en 1959 con el triunfo de la revolución, y la metamorfosis literaria que 
ocurre a partir de ese momento, existen críticos que difieren de tal propuesta. Entre ellos figura Lisandro Otero, uno de los portavoces de asuntos culturales cubanos, quien en el año 1971 presenta una división diferente de la trayectoria que propone Menton. Primeramente, Otero propone cinco etapas, en lugar de las cuatro de Menton. La primera abarca los dos primeros años de la revolución, un período de "deslumbramiento, toma de conciencia nacional, emotividad y fervor patriótico" (94). En ese sentido, la primera etapa de Otero y la de Menton coinciden. En este período, la obra literaria es de carácter testimonial, y refleja principalmente la lucha contra el régimen de Fulgencio Batista, elemento que coincide con las observaciones del crítico norteamericano. Ésta es una etapa en la que, según Otero, a pesar de algunas defecciones significativas como la de Lino Novás Calvo, "la inmensa mayoría de los autores cubanos apoyó a la revolución" (94).

Otero propone una segunda etapa que, en lugar de extenderse desde 1961 a 1965, como supone Menton, llega solamente hasta 1962. Durante este corto período de dos años, la narrativa responde a ciertos sucesos claves, como la declaración del carácter socialista de la revolución, la campaña de alfabetización, la invasión de playa Girón, la crisis de los misiles, las reuniones de Fidel Castro con los intelectuales y la creación de la Unión de Escritores y Artistas de Cuba (UNEAC), entre otros. Otero afirma que estos eventos provocan polémicas estéticas que más que nada responden al temor a la censura; es decir, las limitaciones de la libertad de expresión artística y las coacciones burocráticas. Aunque la segunda etapa de Menton es más extensa que la de Otero, el factor de la polémica está presente en ambos. Ya se ha visto que Menton asegura que se produce la autocensura entre los escritores en un afán de evitar temas polémicos para no 
ser tildados de contrarrevolucionarios. Según indica Menton, los eventos más representativos de un período de polémica como el aludido aquí, son por un lado la censura del filme $P M$, y por otro la clausura de Lunes, el suplemento cultural del periódico Revolución, dirigido por Carlos Franqui (128). En una mirada retrospectiva, los propios intelectuales al cabo reconocerían que a Lunes no se le concedió el valor que merecía, ya que su publicación fue suspendida a pesar de que el suplemento representaba, de hecho, uno de los grandes logros culturales de la revolución cubana. Antón Arrufat comparte esa opinión afirmando que la revolución no tenía motivos para abochornarse de tan gran empresa: "Con el periódico se recibía un magazín dedicad[o] a lo mejor de la cultura de su momento [. . . ]. Se pudo leer un magazín dedicado a Borges, y entrar en contacto con una serie de artistas que eran desconocidos en Cuba" (cit. en Kirk 71).

La tercera etapa de Otero ocupa el resto de la segunda etapa de Menton (19631965). En ésta, Otero se refiere a una "toma de conciencia internacionalista". Algunos de los eventos importantes de estos tres años son, entre otros, el desarrollo de Casa de las Américas y la culminación de la polémica estética sobre el realismo socialista a través de la obra de Ernesto Guevara, El socialismo y el hombre en Cuba. Según Otero, lo que sucede en la literatura es el surgimiento de una poética de la Revolución, la cual se centra en un documentalismo fílmico. La temática existencialista de la que habla Menton no aparece en la clasificación de Otero, quien centra su atención en "la gráfica como vehículo revolucionario de alta calidad plástica" (94), refiriéndose al auge del cartel gráfico como medio de expresión. En esta etapa, indica Menton, hay una queja general contra la baja calidad de la producción literaria, relacionada principalmente con el realismo socialista. Uno de los críticos que más vehementemente se pronuncia en contra 
de tal mediocridad es José Antonio Portuondo, vicepresidente de la UNEAC, quien critica "una literatura popular y propagandística basada en un vocabulario limitado de forma folklórica o tradicional y [. . .] los vacíos ejercicios formalistas encaminados a encubrir la ausencia total o la pobreza de contenido" (cit. en Menton 133). La mediocridad se debe, en parte, a que según explica Ernesto Guevara, "la culpabilidad de muchos de nuestros intelectuales y artistas reside en su pecado original; no son auténticamente revolucionarios" (14), y que "no hay artistas de gran autoridad que a su vez tengan gran autoridad revolucionaria" (12). Agrega que por otra parte, "los revolucionarios carec[en] de los conocimientos y la audacia intelectual necesarios para encarar la tarea del desarrollo de un hombre nuevo por métodos distintos a los convencionales y los métodos convencionales sufren de la influencia de la sociedad que los creó" (12). Es por eso que Guevara asegura que la solución está en la educación y la auto educación de las masas, que "la sociedad en su conjunto debe convertirse en una gigantesca escuela" (7).

En la cuarta etapa (1966-1968), Lisandro Otero habla del surgimiento de un grupo de jóvenes intelectuales que demuestran una mayor madurez revolucionaria. Según él, ésta es una época de gran polémica de índole ideológica en cuanto al papel de los intelectuales dentro de la revolución. Otero afirma que el intelectual adquiere una nueva conciencia de su papel como contribuyente a una obra común que es la revolución, y no como crítico de ella. Recuérdese que la tercera etapa de Menton abarca hasta 1970, y que éste considera la misma como una etapa de realización inigualable en toda la producción literaria cubana. Si bien Otero no niega dicho desarrollo literario, su perspectiva difiere de la de Menton porque mientras este último adjudica tal desarrollo a un cierto 
relajamiento en la postura oficial, Otero lo relaciona con una verdadera toma de conciencia revolucionaria por parte del intelectual. Es curioso notar que durante un período en el que reina la polémica ideológica en cuanto al papel social del intelectual, surja precisamente tanta producción novelística. Es por eso que Menton ha relacionado tal producción con una actitud relativamente relajada del gobierno frente a la intelectualidad, y agrega que entre las prioridades de los intelectuales del momento está integrarse a la corriente literaria latinoamericana. Otero escoge además el año 1968 como línea divisoria entre las etapas cuarta y quinta, ya que es precisamente en este año que se establece la nueva política gubernamental frente a las artes.

Los tres últimos años de la década de los sesenta son cruciales dentro de la metamorfosis social que venía produciéndose hasta el momento. Desnoes afirma que "el maremoto de la revolución llega a su punto más radical, se produce la Ofensiva Revolucionaria [. . .] y la producción literaria decide probar los límites del margen de seguridad que defina el 'dentro' y el 'fuera' de la revolución. La libertad había llegado hasta lo que cualquier otro país socialista ortodoxo llamaría libertinaje" (538). La importancia del año 1968 tiene una estrecha relación con el caso de Heberto Padilla. El conflicto entre Padilla y el gobierno comienza con la clausura de Lunes de Revolución, en 1961, donde trabaja como editor ${ }^{3}$. Sin embargo, no es hasta 1967 que este caso entra en lo que Menton denomina "su fase dramática" (136). Menton explica que Padilla hace en ese año una crítica muy severa de la novela de Lisandro Otero, Pasión de Urbino. Asimismo, Padilla protesta contra el hecho de que no se publicara en Cuba la novela Tres

\footnotetext{
${ }^{3}$ Heberto Padilla era editor de Lunes, conjuntamente con Pablo Armando Fernández, José Álvarez Baragaño y Guillermo Cabrera Infante, quien era el jefe de redacción.
} 
tristes tigres de Guillermo Cabrera Infante, asegurando su superioridad sobre la novela de Lisandro Otero. Cabrera Infante, indica Béjar, "había perdido el beneplácito oficial, desde su deserción en 1965" (27). Con todo, Menton afirma que las consecuencias o repercusiones de la política del gobierno frente a la intelectualidad cubana no se hacen evidentes hasta 1971. Cabe destacar que, entre 1968 y 1971 la posición del gobierno se iba delineando paulatinamente. Existe un sinnúmero de publicaciones y declaraciones en nombre del gobierno que demuestran que el relajamiento en la postura oficial del que habla Menton tal vez no era tal. Es posible que no fuese hasta estos años que el gobierno llegara a una conclusión concreta sobre cuál debía ser la postura oficial frente a la intelectualidad y cuál era el comportamiento adecuado para un intelectual revolucionario, comportamiento que respondiese a su papel dentro de la sociedad.

El propio Menton menciona una serie de artículos periodísticos publicados en 1968, artículos que aunque están firmados por un tal Leopoldo Ávila, hay indicios de que ése era sólo un seudónimo utilizado por José Antonio Portuondo ${ }^{4}$. Guillermo Cabrera Infante es el primer blanco de las denuncias de Ávila: "Fue este Mr. Kein [Cabrera Infante utilizaba el seudónimo de Caín] el primero en abrir el cauce al individualismo, la vanidad, la superficialidad y la extravagancia en el arte. Contaminó a más de un trepador que aún sigue dando guerra. Pero es útil analizar este caso y observar cómo siempre actitudes como las suyas terminan en el basurero de la contrarrevolución" (cit. en Menton 138). Es evidente que en este artículo, que fue publicado en Verde Olivo, el diario de las fuerzas armadas cubanas, se pone de manifiesto la postura del gobierno frente al intelectual en general, así como su reacción frente a la irreverencia. Uno de los aspectos

\footnotetext{
${ }^{4}$ Es Lourdes Casal quien señala que Ávila y Portuondo son la misma persona (Menton 139).
} 
que critica Ávila en la obra de Cabrera Infante es el individualismo, algo que lejos de ser una virtud literaria, se ha convertido en una actitud contrarrevolucionaria, ya que no corresponde con las necesidades colectivas de una sociedad revolucionaria. Por otra parte, queda muy claro en este artículo cuál es la actitud del gobierno frente a los intelectuales que se niegan a asumir una postura revolucionaria.

Además de Cabrera Infante, otros escritores son severamente criticados por Ávila. Por ejemplo, escribe que "[1]a poesía de Padilla no sólo es contrarrevolucionaria, sino mala [. . . ]. Se trata de alertar y alertarnos de cuánta basura contra el pueblo flota todavía en nuestro país" (139). Según Ávila, la contrarrevolución se hace igualmente evidente en la poesía de Padilla a causa de la vanidad, aspecto que también critica en Cabrera Infante. Asimismo, la obra de teatro Los siete contra Tebas de Antón Arrufat recibe el sello de contrarrevolucionaria. Aunque no lo expresa abiertamente, ya el título del mismo (“Antón se va a la guerra") predice el carácter antagónico que se le da a la obra de Arrufat. De hecho, el Comité Ejecutivo de la UNEAC cataloga Los siete contra Tebas como una "interpretación distorsionada al estilo imperialista de la invasión norteamericana a Cuba, bajo el disfraz de una adaptación de la obra de Esquilo" (Menton 141). Por otra parte, Ávila critica la concesión del premio UNEAC a esta pieza que Menton considera una crítica poco disfrazada de la falta de libertad y del incumplimiento de promesas por parte del gobierno revolucionario. Ávila asegura que la concesión del premio se produce únicamente a causa de la composición del jurado (según él, amigos de Arrufat) y no por la calidad literaria de la obra. Arrufat cuenta que, a raíz de la entrega del premio, es enviado a trabajar como ayudante en una biblioteca municipal de Marianao donde permanece por nueve años en el anonimato y el ostracismo, trabajando en el 
almacén donde amarra paquetes de revistas con sogas: "Allí no podía contestar el teléfono, ni recibir visitas, mucho menos escribir" (cit. en Kirk 80).

En el resto de los artículos escritos durante este año, la crítica de Ávila se torna más generalizada, tal vez porque la actitud antagónica e irreverente de los intelectuales se sobrepone a casos individuales. En lugar de lanzar alguna crítica a un intelectual determinado como lo había hecho hasta el momento, Ávila denuncia una tendencia general hacia una falta de conciencia política dentro de la intelectualidad cubana. Critica que la obra literaria cubana no refleje momentos heroicos y logros de la revolución, ya que eso sólo demuestra una escondida y mal disimulada actitud contrarrevolucionaria por parte de los intelectuales. Ávila declara sin tapujos cuál es la posición del gobierno frente a tales actitudes: "A la Revolución no le ha interesado ni le interesa limitar la imaginación ni la experiencia artísticas, sino desarrollarlas; pero no va a dejar de combatir a los que pretenden utilizar esa libertad [. . .] para clavarle a la Revolución un puñal por la espalda" (Menton 140). Esta idea refleja fielmente aquélla expresada por Fidel Castro en sus Palabras a los intelectuales, discurso pronunciado el treinta de junio de 1961 en la biblioteca Nacional José Martí, en el que dice abiertamente:

Creo que esto está bien claro: ¿Cuáles son los derechos de los escritores y de los artistas, revolucionarios o no? Dentro de la Revolución, todo; contra la Revolución, ningún derecho [. . .]. Ya es hora de que ustedes, organizadamente, contribuyan con todo su entusiasmo a las tareas que les corresponden en la Revolución y constituyan un organismo amplio, de todos los escritores y artistas. (cit. en García Luis 81-82) 
Si bien Palabras a los intelectuales data de 1961, no es hasta 1971 que se podrán sentir los efectos de una postura oficial que va tornándose gradualmente más estricta. En 1971 se divulga la "política cultural" de la revolución, y se censura incluso el diversionismo ideológico de obras que no tuvieran que ver con la revolución, aunque no fueran contrarrevolucionarias. Y es precisamente en este año que ocurre el suceso que marcará el comienzo de una nueva era dentro de la época revolucionaria. Es el momento en que se proclama abiertamente el destino de la intelectualidad cubana, el cual no sufrirá ningún cambio hasta finales del siglo XX. Se trata de la detención de Heberto Padilla, que culmina un mes más tarde con una confesión que sorprende a muchos miembros de la intelectualidad internacional. Numerosos intelectuales y escritores se pronuncian en contra de la detención de Padilla, entre ellos Julio Cortázar, Carlos Fuentes, Octavio Paz, Juan Goytisolo, Jean-Paul Sartre, Simone de Beauvoir, Gabriel García Márquez y Mario Vargas Llosa. Varios de estos intelectuales son signatarios de una instancia enviada por el diario francés $L e$ Monde ${ }^{5}$, donde se expresa la preocupación por la detención de Padilla, la cual parece injustificada. En una intervención frente a los miembros de la UNEAC, el mismo día en que es puesto en libertad, Heberto Padilla pronuncia un discurso que luego se publica en Casa de las Américas, ocupando doce páginas de doble columna. En él, Padilla se retracta clara y rotundamente de la actitud que había mantenido hasta el momento. Es un discurso de severa autocrítica donde revisa todos los errores que, según él, ha cometido: "Yo he cometido muchísimos errores, errores realmente imperdonables, realmente censurables, realmente incalificables [. . .]. Yo siempre preferí mis

\footnotetext{
${ }^{5}$ La instancia fue publicada el 9 de abril de 1971. Padilla había sido detenido el 20 de marzo de ese mismo año.
} 
justificaciones, mis evasivas, porque yo siempre encontraba una justificación a una serie de posiciones que realmente dañaban a la Revolución" (cit. en Menton 191). Entre los errores a los que Padilla se refiere están haber atacado injustamente a su amigo Lisandro Otero y haber defendido a Guillermo Cabrera Infante, al que llama "un agente de la CIA" (191), y sobre todo, de haber escrito un libro contrarrevolucionario como Fuera del juego.

Padilla va más allá de la autocrítica para denunciar a otros intelectuales, a los que critica por no tomar el camino "revolucionario" que él ha adoptado. Asegura, cuando se refiere a estos intelectuales: “[P]ensarán que con igual razón la Revolución no podía seguir tolerando una situación de conspiración venenosa de todos los grupitos de desafectos de las zonas intelectuales y artísticas" (Menton 198). Padilla cataloga a aquellos que hasta el momento habían compartido su punto de vista (comenzando por su esposa Belkis Cuza Malé) de ser unos resentidos, amargados, desafectos, enfermizos y contrarrevolucionarios. Pero en cuanto al gobierno y a la agencia de la Seguridad, Padilla los califica de "un grupo de compañeros esforzadísimos, que trabajan día y noche para asegurar momentos como éste, generosidades como ésta" (202). Sin embargo, veintitrés años más tarde, en una ponencia que presenta en Estocolmo, durante un encuentro entre escritores cubanos, Padilla adopta nuevamente una actitud crítica y autocrítica, pero desde una óptica diametralmente opuesta. "Nosotros [. . .] somos parcialmente responsables, desde nuestra función de escritores, de haber mantenido silencio cuando debimos hablar, de haber aprobado cuando debimos objetar, de haber colaborado en más de una ocasión en la búsqueda de una base teórica que justificase la represión que 
algunos sufrimos" $(42)^{6}$. Una afirmación como la anterior indica la validez de lo que muchos de los intelectuales del ámbito internacional afirmaron en 1971: que la retractación de Padilla no había sido genuina, sino producto de la coacción

\section{La década de los setenta: Redefinición de la relación creador-Estado}

En su libro Caminata por la narrativa latinoamericana (2002), Seymour Menton presenta una cuarta etapa que abarca desde 1971 hasta 1974. Según el crítico, en esta etapa predominan el realismo socialista y la novela ideológica. A raíz del caso de Heberto Padilla, la literatura se convierte en una literatura comprometida con rigor ideológico necesario para la creación del nuevo revolucionario. Se produce una oposición casi total a las visiones individualistas, sectarias, de raíces burguesas o decadentes. Esta postura refleja un actitud que Edmundo Desnoes explica cuando dice que la unidad es un elemento fundamental en toda revolución, "aunque la unidad pueda convertirse luego en una limitación, la posible represión de cualquier opinión independiente" (xix). Y en busca de tal unidad, el objetivo literario se torna popularista y de formación ideológica, aspectos que perduran en la producción literaria desde 1971 hasta el comienzo de la década de los noventa. Entre las novelas que destaca Menton están Concierto barroco y El recurso del método (1974), La consagración de la primavera y El arpa y la sombra (1979) de Alejo Carpentier?

\footnotetext{
${ }^{6}$ Al decir "nosotros", Padilla incluye a Jesús Díaz, a Manuel Díaz Martínez, a Pablo Armando Fernández, a Antón Arrufat y a Pepe Triana.

${ }^{7}$ La obra de Carpentier fue publicada, en su mayor parte, en el extranjero, a pesar de éste haber mantenido una intachable conducta según los parámetros revolucionarios. El gobierno cubano mantuvo al escritor alejado de la isla mediante la asignación de un puesto diplomático en Francia, convirtiéndolo así en un alto representante internacional de la revolución, y aislándolo a la vez de las circunstancias isleñas.
} 
La retractación de Padilla tiene un efecto que es de esperarse. Su discurso es criticado por miembros de la izquierda literaria latinoamericana y también de la europea. Se considera que las palabras de Padilla no son sino una confesión al estilo estalinista. Muchas de las personalidades que anteriormente habían protestado por el encarcelamiento de Heberto Padilla, con la excepción de Cortázar y García Márquez, protestan ahora por su confesión. Los intelectuales que se unen a esta protesta son catalogados de "mafia de intelectuales burgueses seudoizquierdistas", "agentes de la CIA" y "ratas intelectuales" (Menton 149). Son esos los calificativos que utiliza Fidel Castro para referirse a la izquierda literaria de Latinoamérica y Europa, durante el Primer Congreso Nacional de Educación y Cultura, en abril de 1971. Es justamente en este congreso que se establece oficialmente la nueva política del gobierno frente al arte y la literatura. Las pautas establecidas en esta nueva política remplazan de manera definitiva aquéllas establecidas diez años antes en Palabras a los intelectuales.

La nueva política gubernamental frente a las artes se funde en un ideario que rechaza todo vestigio de la sociedad y la cultura burguesas. Entre los puntos más importantes de la nueva política está el hecho de que a partir de ese momento, el arte se convierte exclusivamente en un arma de la revolución, un arma que pertenece a las masas y no a una élite. Por otra parte, un punto de gran importancia tiene que ver con la formación ideológica de los jóvenes escritores y artistas, a los cuales había que educar en el marxismo-leninismo. La valoración política del arte aparece como otra de las prioridades; es decir, que la función del arte y la literatura es formar a la juventud dentro de la moral revolucionaria. El propio Fidel Castro afirma en este congreso que no hay valor estético si no hay contenido político. Una obra literaria apolítica es vergonzosa e 
inaceptable. Como consecuencia de esta nueva definición del valor estético, dictada por el gobierno, y con el comienzo del llamado "quinquenio gris", queda eliminada la producción literaria en el género de la ciencia-ficción. Como lo indica Juan Pablo Noroña, durante la década de los sesenta, este género había gozado de cierto auge con obras como La ciudad muerta de Korad (1964) de Oscar Hurtado y ¿Adónde van los cefalomos? (1964) de Ángel Arango, entre otros. Noroña afirma que el desarrollo inicial del género de la ciencia-ficción responde particularmente a un fuerte patrocinio estatal, dictado a su vez por la intención de incorporar a "las grandes masas populares a la categoría de consumidor artístico-literario" (1). No es sorprendente que con el viraje literario y artístico hacia el "realismo socialista" quedaran suprimidos, e incluso prohibidos, los géneros relacionados con la fantasía, como la ciencia-ficción y los cuentos de hadas. Como afirma Linda Howe, "punishment for the slightest ideological dissent or lack of commitment led prudent artists to reach for "revolutionary" metaphors, which lowered standards of artistic judgment" $(18)^{8}$. La nueva política estatal incluye asimismo a los intelectuales y artistas extranjeros porque “... se precisa establecer un sistema riguroso para la invitación a los escritores e intelectuales extranjeros, que evite la presencia de personas cuya obra e ideología están en pugna con los intereses de la Revolución" (cit. en Menton 149-51) 9

\footnotetext{
${ }^{8}$ Howe continúa explicando que "The government's insistence that the proper role of artists was to extend the "revolutionary" political struggle into the realm of culture had lamentable effects on the independence of the art world and the rich variety of Cuban cultural life" (18).

${ }^{9}$ Menton ofrece una relación textual de los diez puntos que aparecen en el discurso pronunciado por Fidel Castro durante el discurso de clausura del Primer Congreso Nacional de Educación y Cultura. La síntesis es nuestra.
} 
Es precisamente en 1971 que el gobierno de la isla realiza un acercamiento hacia la economía de mercado que, si bien tímido, produce algunos cambios socio-económicos. La tensión entre Cuba y la URSS disminuye, y ésta le vende petróleo a la isla a precios muy inferiores al del mercado mundial. Por otra parte, Cuba entra en el Consejo de Ayuda Mutua Económica (CAME) formado por la URSS y los países de Europa del Este (Mesa Lago 26). La consecuencia directa es que con tales cambios, comienza a disminuir la tensión entre Cuba y la URSS, y se produce un retorno al modelo socialista soviético, donde el popularismo y la formación ideológica alcanzan un auge aún mayor que el de finales de la década anterior. Todos estos cambios económicos se ven a su vez reflejados en la producción literaria del momento, ya que con ellos las pautas gubernamentales en cuanto a la labor del intelectual en la sociedad socialista sufren un nuevo giro.

Según Menton, en el período 1971-1974, se produce una brusca merma en la producción literaria, la cual disminuye a un total de menos de diez novelas, en contraste con las más de treinta que se publican entre 1966 y 1970. Antón Arrufat considera que la década de los setenta, desde el punto de vista cultural, es un fracaso absoluto: "No consiguieron nada de lo que se proponían, ni siquiera crearon una tradición de literatura infantil". Cuando todo intento falló, entonces el Ministerio del Interior ordenó a algunos de sus miembros que escribieran novelas policíacas (cit. en Kirk 81). Además de un marcado descenso en la producción literaria y en su calidad, otro de los resultados de la nueva política gubernamental se refleja en la concesión de premios literarios como el Casa de las Américas y el UNEAC. Estos premios, que se otorgan sólo a novelas cubanas “ideológicamente correctas", quedan desiertos algunas veces, o se otorgan a escritores extranjeros (Menton 402). En 1970 y en 1971, el premio Casa de las Américas se 
concede a la novela de Miguel Cossío Woodward, Sacchario, y a la de Manuel Cofiño López La última mujer y el próximo combate, novelas que reflejan de manera fidedigna la ideología aceptada. Según Menton, ambas novelas difieren de las escritas anteriormente por ser menos audaces en cuanto a la experimentación literaria, en que además sitúan la mayor parte de la acción en el campo (la novela anterior era básicamente urbana), y sobre todo en que tocan temas de índole revolucionaria como la zafra y la lucha contra el ausentismo laboral.

En cuanto al estilo, estas novelas reflejan la lealtad a la política igualitaria del Estado socialista, evitando, por ejemplo, referencias eruditas y diferencias dialectales. En cuanto a La última mujer y el próximo combate, es un texto consagrado como novela revolucionaria ejemplar. El propio Menton la considera un ejemplo de "novela de refinamiento ideológico, mientras que el crítico oficial José Antonio Portuondo afirma que "constituye una realización feliz de novela revolucionaria [. . .] al servicio de una intención clara y definidamente política: exponer el proceso dialéctico del nacimiento de una conciencia socialista" (cit. en Menton 408). Por otra parte, Desnoes opina que esta novela representa tanto las virtudes como las fallas de los modelos literarios adoptados por la revolución. La virtud principal es que se haya leído ampliamente; la falla, que haya simplificado la complejidad de la realidad y los personajes que representaba, lo cual, afirma Desnoes, es "un principio de degeneración espiritual" (550).

Menton observa un aumento significativo en la producción literaria en el período que abarca desde 1975 hasta 1987, al menos en el aspecto cuantitativo. Este aumento, afirma, es un tanto paradójico ya que la postura del gobierno sigue siendo la misma. La explicación de tal aumento puede estar en el nuevo tipo de novela que se escribe: las 
novelas detectivescas, de contraespionaje e históricas. Por otra parte, éste es un período en que Cuba interviene más abiertamente en los conflictos del Caribe y África. Las novelas policíacas, de contraespionaje e históricas subrayan la identificación de Cuba con estos conflictos. Además, la novela policial se convierte en la voz de la política oficial revolucionaria ya que, como afirma Desnoes, estas novelas se encargan de desenmascarar a todo tipo de elementos indeseables: "pseudorevolucionarios, vagos, antisociales, jóvenes ideológicamente descarriados, funcionarios con resabios pequeñoburgueses, y puro lumpen proletario". El mensaje recurrente en las novelas detectivescas o policiales es: "la contrarrevolución nunca paga" (550).

El género de la novela detectivesca alcanza su máxima expresión en el año 1976 con El cuarto círculo de Luis Rogelio Nogueras y Guillermo Rodríguez Rivera. Los autores son precisamente los que más tarde presentan su obra como ejemplo de lo que debe ser una verdadera obra detectivesca revolucionaria. La novela detectivesca, para ser considerada revolucionaria, como lo es El cuarto círculo, debe cumplir cinco requisitos: El criminal no es el enemigo de una víctima personal, sino del Estado; el detective, es decir el protagonista, no es un aficionado brillante ni un detective particular que ponga en ridículo la mediocridad policial, sino que representa la moral intachable de una fuerza policial eficaz y bien entrenada; el investigador cuenta con la ayuda de los ciudadanos, en especial, de los Comités de Defensa de la Revolución; la inteligencia del investigadorprotagonista es tan importante como el trabajo en equipo de la sociedad socialista; el propósito de la obra policíaca no es sólo divertir, sino también investigar las causas sociológicas y psicológicas del crimen (Nogueras 13-14). Leonardo Padura Fuentes, quien en la década de los noventa se convertiría en un autor de gran renombre por sus 
novelas detectivescas, califica la novela policíaca anterior como maniquea y de dudosa calidad artística, que tiene el propósito expreso de defender los principios de la revolución y no de cumplir (en tanto que literatura) una función estética (323).

El auge de la novela policíaca en este período es tal, que "llega a considerarse el género idóneo para reflejar la política oficial de un país que vive en un estado de alerta continua ante la posible agresión de sus muchos enemigos, tanto externos como internos" (Castells 22). La producción de novelas policíacas es muy extensa, y los requisitos de Nogueras, a los cuales se ajusta la novela policíaca de los setenta, pierden un poco de vigencia ya que, según Amelia S. Simpson, se observa una mayor flexibilidad de técnicas y temas y "desarrolla una base ideológica más compleja respecto a la realidad social del país" (cit. en Castells 23). Y es precisamente en 1980 que la realidad social de Cuba sufre un cambio drástico cuando un grupo de 10.000 cubanos se refugia en la embajada del Perú, seguido de otro suceso de importancia capital que es el gran éxodo del Mariel. Es comprensible que, en un período de inestabilidad social como éste, también se produzcan cambios visibles en la literatura.

Esta quinta etapa también se caracteriza por la popularidad de las novelas históricas. La nueva tendencia comienza en 1976 cuando se publica la novela Los guerrilleros negros, de César Leante, la cual gana también el premio UNEAC de $1975^{10}$. Los guerrilleros negros responde, según Menton, a la política del gobierno de hacer resaltar las raíces africanas de la nación cubana, lo cual ya se había logrado en 1968 con la publicación de Biografia de un cimarrón de Miguel Barnet (416). El compromiso

\footnotetext{
${ }^{10}$ Podemos suponer que al recibir el premio UNEAC, la novela de Leante pertenece a la categoría de "solvencia ideológica", ya que ése era un requisito para la concesión del premio.
} 
revolucionario de la novela de Leante se refleja a través de una temática que presenta la participación de Cuba en los conflictos de África y del Caribe. También, por su forma esta novela se adscribe a la política oficial del gobierno, mediante una historia narrada de modo lineal y un estilo sencillo que permitiesen el fácil acceso de las masas, y no sólo de un público selecto.

Un sinnúmero de novelas históricas se produce en este período y, al igual que Los guerrilleros negros, éstas de un modo u otro reflejan distintos niveles de compromiso ideológico con la revolución. Una novela que aventaja a la de Leante en cuanto a su calidad literaria es La consagración de la primavera (1978) de Alejo Carpentier. Para Menton, ésta es una obra verdaderamente importante, una especie de épica de la revolución cubana. Menton resume ciertas características de esta novela de Carpentier, mediante las cuales se demuestra el compromiso político del autor para con el gobierno cubano, si bien en las obras de Carpentier no aparece ninguna revolución exitosa. Según el crítico norteamericano, la primavera representa el nacimiento de una nueva generación de cubanos bajo el mando de Fidel Castro. Asimismo, el título se refiere a la conversión política de la bailarina rusa Vera y de Enrique, arquitecto cubano. La nueva raza cubana se presenta a través del matrimonio entre un negro pobre y una blanca rica. Un aspecto que indudablemente refleja la política oficial es la presencia de un miembro ejemplar del Partido Comunista, un trompeta mulato de Santiago de Cuba. El enfoque internacional de la novela representa la participación de Cuba en conflictos antes mencionados. Por último, se encuentra el hecho de que Carpentier sacrifica su experimentación artística para hacer de su novela un texto algo más asequible a las masas (Menton 418-19). Sin embargo, a pesar de dicho sacrificio, queda la interrogante de cuán asequible puede ser 
una novela histórica de más de seiscientas páginas de cargado lenguaje barroco carpenteriano.

\section{La década de los ochenta: Gestación del pensamiento crítico y de la experimentación literaria}

La década de los ochenta es de gran importancia en la evolución de la novela cubana de la revolución, ya que aunque los géneros policíacos e históricos alcanzan una gran popularidad y precedencia, también se producen ciertos avances en la novelística. Se trata del nacimiento de una nueva generación de escritores en cuyas obras se constata un cambio de tendencias. Menton cita como ejemplo a Manuel Pereira, cuya novela, $E l$ comandante Veneno (1979), trata el tema de la alfabetización de los campesinos en la sierra. El aspecto innovador en esta novela es que no presenta los matices propagandistas de novelas como Maestra voluntaria (1962), que trata la misma temática. Pereira hace hincapié en las precarias condiciones de vida de los campesinos (un verdadero reto para la revolución), y no se ocupa precisamente en enaltecer la labor de los brigadistas (un logro de la revolución).

Otra novela que presenta el cambio de tendencias en la novelística cubana de los ochenta es Un rey en el jardin de Senel Paz (1983). Entre las características que reflejan las tendencias literarias de Paz está el hecho de que el protagonista es un joven sensible que habla con las flores, muy al estilo del Celestino de Arenas, en lugar del típico héroe revolucionario. La visión revolucionaria del mundo se presenta a través de un hombre herido que se convierte en el héroe espiritual del joven. Menton coincide con la idea de que estas novelas, entre otras de la época, pueden reflejar el nacimiento de una nueva generación de escritores cuyas obras van a incorporar una mayor experimentación 
lingüística y estructural, sin chocar con la política del gobierno (426). Arrufat afirma que la década de los ochenta es buena para la literatura, buena en la medida en que contrasta con la década anterior. Entre los cambios que ocurren, Arrufat habla de los escritores y artistas que habían sido excluidos debido a su homosexualidad, considerada por el gobierno una aberración política. En los ochenta, esos escritores y artistas son readmitidos. Asimismo, los escritores comienzan a ofrecer conferencias y se les facilita viajar y publicar en el extranjero, algo que hasta el momento sólo se podía hacer por mediación de la UNEAC, y casi siempre en los países socialistas (cit. en Kirk 84).

Pero ya para el año 1986, el gobierno de la isla ha abandonado el período pragmatista que adoptara en esos últimos años, y regresa, según afirma Mesa-Lago, a un nuevo ciclo idealista de autocrítica al que le da el nombre de "Proceso de Rectificación de Errores" refiriéndose a la rectificación de los "errores idealistas" $(29)^{11}$. Entre los cambios que ocurren durante el nuevo ciclo están la eliminación de las granjas privadas, la prohibición de los mercados libres campesinos y del trabajo por cuenta propia, la restricción de la "permuta" y construcción de viviendas, la expansión del racionamiento, y la reintroducción del trabajo voluntario. Además, se ve la creación de brigadas de construcción organizadas al estilo militar, el retorno a la movilización laboral masiva, la reducción drástica de los incentivos materiales y el énfasis en el igualitarismo y en los servicios sociales gratuitos. Hay a su vez, un intento, por parte del gobierno, de crear una especie de resurrección de la figura de Ernesto Guevara y su ideal del Hombre Nuevo.

\footnotetext{
"Mesa-Lago cataloga este ciclo de "idealista", ya que las metas establecidas por el gobierno son realmente inalcanzables. Sin embargo, el gobierno cubano insiste en que dichas medidas no son sino correcciones de "errores idealistas", apelativo que utiliza para referirse a ciertas medidas que anteriormente habían dirigido a la isla hacia la economía de mercado.
} 
El optimismo oficial, que Mesa-Lago cataloga de exagerado, lejos de extenderse a la población, crea en ésta un gran descontento, ya que la situación económica ha empeorado considerablemente. El proceso de rectificación de errores requiere mayor control gubernamental y una estricta ortodoxia ideológica, que contrastan marcadamente con la tendencia hacia las reformas de tipo liberal que se producían en la Unión Soviética durante el gobierno de Gorbachev. Como bien indican Edward González y Kevin F. McCarthy, "The fact that Cuba was reverting to heightened centralization and bureaucratic and ideological controls at the very moment that the Soviet Union was surging ahead in an attempt to humanize communism surely was not lost on some of Cuba's more observant, liberal-minded youth" (38). El descontento y la desilusión de la juventud cubana representan un gran revés en el intento de resucitar las ideas de Ernesto Guevara. Recuérdese que Guevara veía en la juventud una especie de arcilla fácilmente moldeable, el sector más indicado de la población para crear al Hombre Nuevo, al hombre socialista del futuro, motivado por incentivos morales en lugar de materiales.

Así como la juventud se muestra indiferente ante el socialismo cubano, el modelo propuesto por Guevara había sido abiertamente traicionado, ya que mientras éste había recalcado la importancia de hacer del Partido Comunista un partido de las masas, en el año 1986 había una sobre representación de la élite, tanto en el Partido como en su Comité Central. Jorge Domínguez indica: "The party changed course. It has become more of an elite party, more capable of governing, but also less representative. And the party's Central Committee is even more the elite of the elite" (7). Domínguez indica que el 78\% del Comité Central poseía una educación universitaria en 1986. No obstante, lo cierto es que Guevara no se refería al ámbito académico cuando hablaba de educar a las 
masas, sino que instaba a educarlas en la doctrina socialista para así lograr una incorporación de las mismas en el camino hacia el comunismo. Es decir, el papel de las masas populares en el liderazgo del país había seguido un proceso inverso al propuesto por el Che. Mesa-Lago afirma que hay suficientes indicios de que las medidas políticas y económicas tomadas durante este ciclo provocaron una recesión. La tasa de crecimiento económico es negativa, resurge el déficit fiscal y continúa aumentando el desempleo (2930). Cabe destacar que donde Menton habla del nacimiento de una nueva generación de escritores, Mesa-Lago sitúa la recesión económica que provoca tanto descontento entre la población. Si bien la nueva generación a la que se refiere Menton muestra interés por la experimentación lingüística y estructural sin irrespetar las reglas oficiales, el nacimiento de una nueva tendencia literaria se produce como resultado directo de una nueva realidad socioeconómica.

Leonardo Padura Fuentes ofrece su propia visión panorámica de la evolución de las artes y la literatura cubanas a partir del triunfo de la revolución. Su perspectiva presenta un marcado contraste entre la situación que se perfila en esta época y la de las décadas anteriores. Padura cataloga los años sesenta como una década de expansión y compromiso abierto del arte cubano con el proceso revolucionario. Por otra parte, la década de los setenta es, a su modo de ver, de plena concreción del proyecto cultural socialista drásticamente aplicado a una sociedad que mayoritariamente había apoyado la revolución (324). Pero en la década de los ochenta, comienzan a suscitarse cambios realmente decisivos. Ésta es la década en que muchos de los artistas que habían sido castigados por sus creencias religiosas, sus preferencias sexuales y sus cuestionamientos son reintegrados y rehabilitados. Según Padura, es justamente durante estos años que 
surge una generación de escritores que, nacidos en la década de los cincuenta, traen "en su conciencia la tranquilidad de no haber cometido el pecado que, a fuerza de repetirlo, cre[en] haber cometido sus antecesores: no haber participado de manera más directa en la gestación de la revolución" (324). Son estos escritores y artistas los que, muy tímidamente, comienzan a crear un arte comprometido, pero no con el proyecto revolucionario, sino con la función estética del arte. Este proceso evolutivo alcanza su madurez en la década siguiente, durante uno de los períodos más convulsos de la historia de la revolución cubana.

\section{El Período Especial en Tiempos de Paz: El surgimiento de una nueva literatura}

La caída del muro de Berlín y del bloque socialista en Europa del Este, al igual que el desmembramiento de la Unión Soviética, tienen profundas repercusiones en el destino de Cuba y la vida de su pueblo, ya que la isla queda sumida en lo que Leonardo Padura llama "una espantosa soledad política y económica" (324). Julio Carranza-Valdés habla de "un pesimismo generado por el destino final de la Perestroika y la experiencia socialista de Europa Oriental" (1). Con la desaparición del CAME, Cuba pierde el apoyo económico de la Unión Soviética; es decir, que desaparecen los subsidios y los préstamos blandos. Asimismo se paraliza la inversión soviética en numerosos proyectos. El CAME, indica Carranza-Valdés, había sido la única alternativa de Cuba frente a la política de bloqueo que los sucesivos gobiernos de los Estados Unidos mantuvieron contra la isla (2). Según afirma Mesa-Lago, el comercio exterior cubano cae un $75 \%$ porque aproximadamente el 70\% de éste era con la URSS (30). Rusia deja de importar níquel, cítricos, puros y otros productos cubanos y el comercio entre Cuba y Rusia se limita al canje de azúcar por petróleo, pero en cantidades muy reducidas y a precios de mercado 
mundial (30). Además de factores externos como los anteriores, la crisis de este período se debe igualmente a factores internos ${ }^{12}$. Básicamente, las medidas tomadas en el ciclo anterior (1986-1990) iban "a contrapelo de las corrientes mundiales" orientadas hacia la economía de mercado (30). El regreso al estímulo no material y el descabellado plan para alcanzar la autosuficiencia alimenticia constituyen un fracaso, ya que ponen la economía cubana en una posición sumamente desfavorable para enfrentar la transición que se producía en Europa del Este. Mesa-Lago señala la intensificación del bloqueo de los Estados Unidos como otro de los factores que contribuyen al desmoronamiento de la economía nacional cubana. Este deterioro económico provoca el inevitable recrudecimiento de la pobreza en la isla.

$\mathrm{Al}$ impacto económico se une el desencanto que produce, entre muchos, la muerte del ideal del Hombre Nuevo. González y McCarthy afirman que los sucesos que tienen lugar en Europa del Este a partir de 1989 acentúan la división entre el viejo liderazgo revolucionario y la juventud: "Politically, the young now had more reason than ever to doubt the competence of the regime's top leadership. Ideologically, they could see that Cuba was virtually alone and struggling against the tide of history. Economically, and most disturbing of all, their own futures looked bleak" (39). El intento de revivir los ideales guevaristas ha resultado fallido por la gravedad de los problemas sociales que se derivan de los económicos, como el ausentismo y el desempleo. Las aspiraciones personales de muchos se ven frustradas, y la preparación académica se torna, para muchos jóvenes, completamente inútil en una economía que linda con la ruina total. La

\footnotetext{
12 Mientras que Mesa-Lago se refiere a factores externos, Carranza-Valdés los cataloga de "fracturas abruptas en las articulaciones internacionales de la economía cubana" (2).
} 
disminución drástica tanto de las exportaciones como de las importaciones produce en la isla una serie de problemas: la aguda escasez de alimentos, combustible y manufacturas; el racionamiento extendido a todos los productos y la reducción de sus cuotas para cubrir sólo la mitad de las necesidades alimenticias mensuales; el crecimiento del mercado negro y de las actividades ilícitas, como el robo en las empresas estatales, y el descenso al mínimo del esfuerzo laboral, aumentando el ausentismo y disminuyendo la productividad. De hecho, el 18 de abril de 1997, el diario Trabajadores publica un artículo en que queda claro que la mayor amenaza para la revolución lo son la vagancia, la irresponsabilidad y la corrupción, y que al igual que las actividades delictivas, éstas equivalen a "la perpetua amenaza del enemigo" (cit. en Crabb 143).

En vista de la innegable tensión interna, el gobierno cubano decide llevar a cabo una serie de reformas con miras a aliviar la crisis. Entre dichas reformas se encuentran la legalización de la posesión y circulación de divisas extranjeras, el envío de remesas por los cubanos residentes en el extranjero, la apertura de tiendas estatales para ventas en dólares, la autorización de varios tipos de trabajo por cuenta propia, la apertura de los pequeños restaurantes caseros conocidos como "paladares", la reintroducción de los mercados libres agropecuarios y artesanales, la creación del peso convertible, y la concesión de permiso a los ciudadanos cubanos para arrendar parte de sus viviendas a los turistas (Mesa-Lago 34-35). Carranza-Valdés parece coincidir con la idea de Mesa-Lago de que los ciclos pragmatistas en los que se produce un enfoque hacia el mercado tienden a favorecer la economía cubana. Al referirse a las recientes reformas económicas Carranza Valdés dice: "El mercado tendría un papel mucho más importante que el que tuvo tradicionalmente en el modelo socialista clásico y en la mayoría de las reformas 
socialistas" (10). García Reyes y López de Llergo indican que como respuesta a la crisis por la que atravesaba el país, el gobierno asegura la realización de ciertos programas de alta prioridad, como el del turismo, la biotecnología y la investigación científica (211). Mesa-Lago reconoce que al contrario de los muchos efectos negativos de dichas reformas, el incremento del turismo internacional tiene repercusiones positivas, aunque casi imperceptibles a causa de la gravedad de la situación económica en general (32).

A pesar del aparente alivio que traen consigo las reformas mencionadas, éstas tienen a su vez efectos negativos dentro de la población. Uno de esos efectos tiene que ver con el incremento de los precios en el mercado informal frente a los salarios, que dejan de ser un estímulo ya que no eran suficientes para enfrentar el alza de los precios. Por consiguiente, se produce una gran desvinculación laboral, la cual se debe también al aumento del cuentapropismo y del mercado negro. En cuanto al campo educativo, Domínguez García observa la reducción de la enseñanza superior y un aumento en la educación politécnica. Con la crisis económica disminuye la motivación juvenil para encaminarse hacia largas carreras académicas, prefiriendo así las carreras cortas de inmediata aplicación en una economía de mercado (Domínguez García 232-33).

Carranza-Valdés habla de efectos negativos "no sólo en términos económicos, sino además en términos ideológicos, cuando el salario, reconocimiento económico y social al trabajo, deja de ser la vía fundamental para la obtención del bienestar personal y familiar" (31). Domínguez García parece coincidir con Carranza-Valdés respecto al aumento de grupos involucrados en "conductas desviadas", ya sea actividades ilícitas o aquéllas que en el pasado habían sido tildadas de "contrarrevolucionarias" (236). Comienza además una tendencia a la movilidad social descendente. Por ejemplo, el 
trabajo intelectual y académico sufre un giro hacia el trabajo manual, y el industrial hacia el agropecuario. Sin embargo, Domínguez García hace una observación muy interesante sobre la movilidad social ascendente que se había reportado en los años anteriores a la crisis: "[M]uchos de los procesos de movilidad ascendente que tuvieron lugar [y que] 'nos acercaban a la estructura social de la sociedad socialista' estuvieron 'inflados', es decir, que no estaban en correspondencia con las condiciones del país y no constituían signos de avance real" (238).

La adversidad económica, como es de esperarse, alimenta la frustración, el desencanto y el enajenamiento de la población. Con el desencanto popular se produce a su vez una gran incertidumbre, la zozobra frente a un futuro que parece tan incierto como convulso el presente. La tambaleante situación socioeconómica provoca además un resquebrajamiento de la base política de la Revolución, observa Mesa-Lago. El año 1994 es de una relevancia descomunal, ya que por primera vez en la historia de la revolución, durante el mes de agosto, miles de habaneros se lanzan a la calle en protesta contra el gobierno. Domínguez García presenta a la juventud cubana como el sector más vulnerable frente a la crisis del momento, tanto antes como después de las reformas económicas. En el comportamiento de la juventud se observan indicios del concepto de “desocialización” propuesto por Damián Fernández (84). Según González y McCarthy, "A significant, and increasingly visible, number of youths literally turned away from the regime's expected norms of conduct by embracing Western pop music, clothing, and fads, often engaging in explicit 'anti-social' behavior, such as taking illicit drugs, stealing, and engaging in prostitution" (40). La juventud también representa el setenta y cinco por ciento de los balseros que abandonan la isla en la década de los noventa. 
Fernández calcula también que alrededor del cincuenta por ciento de los miembros de la Unión de Jóvenes Comunistas deciden no formar parte del Partido Comunista de Cuba llegado el momento de ser elegidos (40).

Entre las actitudes que se desarrollan durante este período están: la incertidumbre ante el futuro, la contradicción entre el individualismo y la solidaridad y la difusión de conductas marginales para satisfacer aspiraciones materiales a corto plazo. Con el aumento del turismo, por ejemplo, aumenta también la prostitución, conocida como el jineterismo. Es irónico que una práctica inicialmente erradicada por la revolución haya llegado a convertirse en un modo de vida para tantos en la década de los noventa. Elisa Facio indica que tanto jóvenes adolescentes como mujeres profesionales ven la prostitución como un nuevo modo de vida, como una única salida para resolver sus problemas económicos y los de sus familias (2). El desarrollo del turismo internacional en la isla parece ser el causante principal del desarrollo de la prostitución, tanto en las mujeres como en los hombres. El turista internacional, además de ser el portador de los tan codiciados dólares, trae consigo los valores de consumo de la cultura capitalista, lo cual a su vez aumenta el número de personas que encuentran en la prostitución la vía más factible para satisfacer sus necesidades económicas.

El acentuado deterioro de los valores morales y el incremento de actitudes oportunistas, sin embargo, no se ven totalmente generalizados entre la juventud. Muchos jóvenes mantienen sus metas personales y buscan las vías de alcanzarlas sin abandonar el proyecto revolucionario. Otros sostienen un fuerte sentimiento nacional y dan igual importancia tanto a las metas individuales como a las colectivas (Domínguez-García 242). Damián Fernández observa que si bien el desafecto de la juventud es indiscutible, 
exceptuando a los que él llama "the loyalists", la oposición es tan compleja como la que propone Domínguez-García. Fernández habla de tres grupos principales; uno que cataloga de los "in-between", quienes mantienen una actitud ambigua hacia el gobierno. Desean que continúen los servicios sociales gratuitos como la educación y el cuidado de la salud, pero a la vez valoran el individualismo y la libertad económica y desean reformas políticas. Sin embargo, este grupo carece de organización política. Por otra parte, afirma Fernández, se encuentra la oposición, jóvenes que, a falta de un movimiento político organizado, han formado organizaciones disidentes o se han unido a las ya establecidas. Por último, están los jóvenes que Fernández cataloga de "variegated and disconnected mass", y que demuestran su rechazo hacia el socialismo cubano mediante actividades y comportamientos que incluyen desde lo civil hasta lo ilegal, desde la asistencia a servicios religiosos hasta participar en la bolsa negra y el contrabando (8689).

En esta última década del siglo XX se sitúa la sexta y última etapa propuesta por Seymour Menton, quien afirma que la crisis socio-económica por la que atraviesa Cuba en la última década del siglo XX disminuye a la vez la severidad de la política cultural de los años anteriores (Caminata 429). Entre los cambios que han ocurrido en el ámbito literario está el reconocimiento (no obstante condescendiente) que han recibido autores anteriormente ninguneados como Guillermo Cabrera Infante, Reinaldo Arenas y Severo Sarduy. Es decir, que por primera vez se incluye la producción de la diáspora en la categoría de literatura nacional. Muchos escritores exiliados se integran al concepto de literatura nacional y son ampliamente estudiados bajo el mismo, como lo son Antonio Benítez Rojo, Jesús Díaz, Carlos Victoria y Zoé Valdés. Entre los escritores cubanos que 
residen en Cuba y que han cobrado gran distinción en la narrativa del momento se encuentran, entre otros, Abilio Estévez, con novelas como Los palacios distantes (2002); Abel Prieto, con El vuelo del gato (2002); Antón Arrufat, con La noche del Aguafiestas (2001); Leonardo Padura Fuentes, con Vientos de cuaresma (2001), entre otros textos policíacos, y la novela histórica La novela de mi vida (2002); y Pedro Juan Gutiérrez con El Rey de La Habana (1999) y Trilogía sucia de La Habana (2000).

Otros estudiosos apoyan la observación de Menton sobre los cambios que han tenido lugar en el ámbito literario cubano de esta última década. John M. Kirk, por ejemplo, afirma que "la literatura de este país —que por largo tiempo, y, sobre todo, durante el famoso quinquenio gris que se vive a partir de 1970, había caído en niveles de calidad realmente mediocres - se ha revitalizado en los últimos años y ya es raro el concurso internacional donde no haya un cubano entre los laureados" (14). Las conclusiones de Kirk se derivan de un proyecto realizado en conjunción con Leonardo Padura en el que se realiza una serie de entrevistas a artistas cubanos residentes de la isla. El propósito de estas entrevistas, según Kirk, es obtener una nueva perspectiva del proceso revolucionario cubano, una mirada retrospectiva e introspectiva, en un momento donde la eficacia de dicho proceso ha sido ampliamente cuestionada ${ }^{13}$.

Los artistas entrevistados por Kirk y Padura tienen algo en común: Muchos no pudieron publicar sus obras durante años, a pesar de ser considerados hoy en día como símbolos de la cultura cubana, como es el caso de la poeta Nancy Morejón. Por otra

\footnotetext{
${ }^{13}$ Kirk indica que él y su colega Padura le presentaron el proyecto a Abel Prieto, quien era el presidente de la UNEAC. Asegura, además, que no se consultó a nadie del gobierno sobre el proyecto, ni éste les impuso ningún tipo de límites en cuanto a los entrevistados o las preguntas que habrían de formulárseles. También aclara que "hoy por hoy, todos los encuestados pertenecen al establishment cultural cubano y gozan de apoyo, prestigio y reconocimiento oficial" (12).
} 
parte, la obra de muchos de ellos ha sido objeto de censura y también de autocensura. Antón Arrufat indica que la autocensura "era tan inconsciente, tan integrada, tan consustancial a la persona del artista" que jamás se le hubiesen ocurrido ideas como la de Fresa y chocolate en las décadas de los sesenta, setenta u ochenta, ya que "se trabajaba mentalmente con los supuestos que estaban incorporados de tal manera que se creaba, sin pensar que había otras zonas de la realidad o del pensamiento que también se podían tocar" (Kirk 84). Asimismo, el mayor reto para muchos de estos artistas ha sido trabajar sin saber dónde se encontraba la línea divisoria entre "dentro de la revolución" y "fuera de la revolución”, precisamente por el carácter inestable de los parámetros establecidos y vueltos a establecer, a medida que cambiaba la postura del gobierno tanto en asuntos internos, como en conflictos internacionales. La perspectiva que proponen Kirk y Padura en su colección de entrevistas le otorga una nueva dimensión al asunto, presentándolo desde la óptica del artista. Según Kirk, estas conversaciones revelan que aunque a la luz del nuevo milenio los conflictos pasados parezcan risibles, los artistas, además de tener talento (que no siempre lo había) debieron aprender, "procurando no equivocarse, hasta dónde podían expresarse sin provocar la intervención de los burócratas” (18).

Si interesante es la visión retrospectiva de los artistas, más lo es aquélla expresada por algunos de los individuos que de alguna manera siempre han formado parte del liderazgo revolucionario. Uno de estos individuos es Roberto Fernández Retamar, considerado el portavoz más fiable de la postura oficial del país, y quien a lo largo de los años ha defendido vehementemente la idea que el intelectual y el artista tienen la obligación de incorporarse y ser partícipes activos del proceso revolucionario. Fernández Retamar critica los excesos cometidos en nombre de la revolución: la fundación de los 
campamentos de las Unidades Militares de Ayuda a la Producción (UMAP) a finales de los sesenta, adonde se enviaba a los homosexuales para "reeducarlos"; el hecho de no publicar las obras de autores cuya posición frente al proceso revolucionario no era "confiable"; y la política de eliminar de reseñas, antologías y diccionarios los nombres de autores exiliados, "como si aquéllos nunca hubiesen existido" (19). Otro líder revolucionario que ha obtenido la admiración de muchos de los artistas entrevistados por Kirk y Padura es Abel Prieto, ministro de cultura y antiguo presidente de la UNEAC. Al parecer, Prieto ha expresado repetidamente su desacuerdo con varias de las normas culturales del gobierno. Tal vez su postura esté relacionada con el hecho de que Prieto también forma parte del sector literario, y que su creación se haya visto limitada por dichas normas. Según Kirk, Prieto "dio algunas batallas contra prejuicios acendrados por años de práctica política respecto a los creadores" (20). La labor de Abel Prieto, según algunos escritores, comienza a dar resultados lentos e imperceptibles, pero de importancia.

Sin embargo, no es hasta la década de los noventa que comienzan a suscitarse cambios drásticos en el ámbito literario y artístico en general. Kirk afirma que de 1994 a 1999, la literatura cubana evoluciona más que en los veinte o treinta años anteriores: "La Cuba de los paladares, las empresas mixtas, los mercados agropecuarios, los cuentapropistas y las iglesias abarrotadas y también la del dólar, la corrupción incipiente y la prostitución, es un mundo nuevo que se ha comenzado a vivir en la isla" (21). Agrega que, por ende, no es tan sorprendente que la política cultural finisecular haya cambiado, llegando a ser radicalmente diferente a la de 1971. Arrufat afirma que la "libertad condicionada" de la que gozan los artistas en Cuba comienza con los pintores, a 
quienes se les permite viajar, exponer en el extranjero y establecer relaciones con galerías en países capitalistas. Arrufat asegura que Abel Prieto ha sido "un hombre providencial para la cultura cubana. Con suma inteligencia ha sabido implementar lo que la revolución se proponía en la cultura, pero de un modo sabio, sutil, espiritual", labor que frente al Ministerio de Cultura ha desarrollado y perfeccionado (Kirk 84). El propio Heberto Padilla, durante su ponencia en el encuentro entre escritores cubanos celebrado en Estocolmo en 1994, agradece la postura de Abel Prieto frente a la intelectualidad cubana: "En mi caso específico, ha sido Abel Prieto, presidente de la UNEAC y miembro del Buró Político del Partido, quien después de veintitrés años de lo ocurrido, considera que fue un error que nunca volverá a repetirse en Cuba" (43).

Las opiniones sobre el papel de la crisis de los noventa y el efecto de la misma sobre los cambios que se suscitan en el ámbito artístico y literario de Cuba varían, aunque por lo general se acepta que el convulso estado de cosas del momento funciona como una especie de catalizador en la creación. Sin embargo, esta relación es bastante compleja y no debe quedarse su estudio en la superficie. Sería demasiado simplista decir que la crisis económica y la frustración popular han sido las únicas causantes de la nueva expresión artística, cuando son tantos los factores por considerar. Padura, por ejemplo, enumera algunas de las consecuencias de los problemas económicos en la industria de producción cultural: "[C]risis en la industria editorial, reducción casi a cero de la realización cinematográfica producida con capital nacional, disminución de los proyectos teatrales, dispersión de la producción plástica, reducción de los horarios de transmisión televisiva y de la producción de programas" (325-26). O sea, que con las dificultades económicas, al 
gobierno se le imposibilita responder a las exigencias de la creación, lo cual produce un estancamiento temporal de la producción artística.

Esta dificultad que enfrenta el gobierno para responder a las exigencias artísticas ha tenido, por otra parte, implicaciones positivas. Se ha producido el imperante crecimiento en los espacios de expresión, lo cual da un nuevo impulso a la creación artística. Instituciones como la UNEAC, el ICAIC y el Ministerio de Cultura han dejado mayor espacio para "la reflexión, el análisis y la crítica de fenómenos y procesos antes censurados o tachados a media" (Padura 326). Padura indica que la falta de apoyo por parte de estas instituciones gubernamentales hacia los proyectos artísticos les ha dado a los artistas más independencia, aumentando las posibilidades de expresión, "dándole el necesario sonido a un silencio que, en realidad, clamaba a gritos por una ocasión que, en medio de la institucionalización anterior, resultaba imposible de concretar" (326). Es decir, que se produce el tránsito del arte subsidiado al incipiente mercado de bienes simbólicos. Y esa misma independencia ha permitido que surjan proyectos alternativos que buscan, ante todo, reflejar las zonas oscuras de la realidad del momento. Estos nuevos proyectos responden entonces a un mercado, ya que son bien recibidos por el público. Este tipo de producción artística continúa en la medida que aumenta la demanda dentro y fuera de la isla. El arte de los noventa contrasta sobremanera con las etapas anteriores, que Padura describe como "el romanticismo épico de los 60, el maniqueísmo ideológico de los 70, y los balbuceos críticos de los 80" (327).

En el mundo literario, especialmente en la narrativa, además de la falta de respuesta editorial provocada por la crisis en la infraestructura, hay cambios en la actitud (o al menos en el comportamiento) de ciertas esferas del Estado, como lo indica el caso 
de Abel Prieto. Pero por otra parte, los autores tienen una apremiante necesidad de reflexionar sobre la difícil y compleja realidad que moldea sus obras. Padura indica que se derriban tabúes y se comienza a tratar temas anteriormente "mal vistos", como el exilio, la droga, la homosexualidad, la corrupción, la desesperanza y el suicidio, al igual que los temas fantásticos ${ }^{14}$. Es decir, que los asuntos que antes hubiesen causado escándalos, reproches y hasta castigos, ahora forman parte del ambiente creativo. No ha de entenderse, sin embargo, que hayan desparecido la censura ni la autocensura del ambiente artístico-literario; sólo que el nivel de tolerancia por parte del gobierno aumenta durante esta década, ya que, como dice Arrufat, la libertad del artista está condicionada por la realidad política y social del país. En definitiva, lo que sucede con la crisis socioeconómica es una expansión inevitable del territorio denominado "dentro de la revolución", un juego cuyas reglas el artista conoce de sobra. La crisis económica, propicia por otra parte la posibilidad de comercialización de la obra artística, algo prohibido hasta entonces. Tanto galerías de arte, como casas editoriales alrededor del mundo trabajan con creadores cubanos, sin la intervención del aparato estatal.

Por otra parte, del seno de la pobreza, el desencanto y la incertidumbre del momento, nace y continúa desarrollándose una nueva corriente literaria cuyas características reflejan, de una forma u otra, el sentir de la generación revolucionaria de los noventa. Las tendencias de la corriente literaria de este período no son sino un reflejo de las nuevas actitudes del cubano frente a su compleja y precaria realidad. Este tiempo de crisis es la causa del nacimiento de nuevas actitudes en el desarrollo de una nueva

\footnotetext{
${ }^{14}$ Como afirman Alberto Chimal y Josefina Pacheco, "[L]a creciente apertura de la isla ha beneficiado a su joven narrativa fantástica y a algunos escritores de generaciones previas que han persistido [. . .]. En buena medida los ayuda el exotismo, la peculiaridad de su situación, que atrae a los compradores ávidos de novedades" (3).
} 
narrativa cubana. Si bien el discurso oficial cubano ha dejado de utilizar el rótulo de Periodo Especial en Tiempos de Paz, la expresión literaria cubana ya ha experimentado una metamorfosis, que demuestra el proceso de maduración que se ha suscitado en el pensar y en el sentir de una generación revolucionaria frente una realidad que es tan cruda para los que la viven en carne propia como para los que la observan desde fuera. Como indica René Vásquez Díaz, "[L]a literatura es uno de los recursos más matizados y penetrantes que posee el hombre para revelar la trama oculta de relaciones humanas y de latencias psicológicas e históricas que condicionan el comportamiento de un pueblo en una época dada" (107). Y son los principales rasgos de esta producción literaria los que ocuparán este estudio. Para explorar las tendencias que surgen en la narrativa cubana, se analizarán textos representativos de esta etapa, escritos a partir de la última década del siglo $\mathrm{XX}$ por autores que viven y escriben dentro y fuera de la isla.

El papel que desempeñan en la narrativa cubana los escritores que residen en el extranjero es un tema que ha provocado gran polémica entre muchos escritores e intelectuales de Cuba. Por ejemplo, Antón Arrufat niega la existencia de una cultura cubana en el exilio, argumento que contrasta con el de Leonardo Padura, quien habla de una cultura cubana creada dentro y fuera de la isla. Arrufat afirma que muchos de los escritores y artistas que trabajan y se expresan en el exilio han hecho una obra importante, pero que ésta será solamente incorporada por la cultura nacional. Sin embargo, la actitud de Arrufat es ambivalente, ya que sí reconoce en la obra de los exiliados "una expresión de la situación que la misma cultura ha creado, y sobre todo, la que ha creado la sociedad cubana" (Kirk 87). Para Yvette Sánchez, los escritores que viven en el extranjero sólo han contribuido a crear una imagen ficticia de Cuba, una 
imagen que, a causa del exilio, se fragmenta. Sánchez indica, además que esa imagen, "en un proceso de palimpsesto, y desde afuera, superpone a la Isla diferentes capas interpretativas, además ficticias". Agrega que los escritores de la diáspora "[n]o viven en [Cuba], la componen, la estetizan acabando por inventar una nación posible” (164).

Sánchez sugiere que las obras creadas en el extranjero carecen de calidad literaria, de experimentación y de virtuosismo, y que después de Reinaldo Arenas no ha habido ninguna revelación literaria fuera de Cuba. Indica que los escritores de la diáspora no muestran en sus obras la búsqueda estética y poética, sino que escriben para "legitimar su nacionalidad" (165). De hecho, acusa a algunos nuevos escritores del exilio de "sacar provecho de que Cuba esté en boga y en oferta, en el resto del mundo" (165). No obstante, y aun si se analiza el asunto desde el punto de vista de Sánchez, la perspectiva de Cuba que ofrece la obra de los exiliados no debe obviarse. La susodicha ficcionalización de la realidad de la Isla no hace sino indicar una plurivalencia de perspectivas e interpretaciones sobre el proceso revolucionario, un dialogismo que ilustra las diversas visiones de una realidad social, visiones que responden a la manera en que cada individuo experimenta dicha realidad.

El dialogismo bakhtiniano revela deferentes niveles de realidad en de la obra literaria. De ahí la validez del argumento de Mercedes Ortega que "la vida del hombre es fundamental para la comprensión y explicación de la obra literaria" (2). Por eso no sería justo explorar las repercusiones de este proceso en la evolución del arte y la literatura cubanos desde una sola perspectiva. Después de todo, el proceso revolucionario cubano también se vive desde fuera, y asumir una actitud excluyente, como la de Sánchez, sería recurrir al lema de Palabras a los intelectuales, sólo que éste leería: "Dentro de la Isla, 
todo. Fuera de la Isla, nada". Como bien indica Heberto Padilla, "[L]a literatura cubana es la misma para cualquier cubano, no importa el país donde resida. Si la condición de exiliado fuese excluyente, ni Heredia ni Martí serían cubanos" (47).

La narrativa finisecular cubana, escrita dentro o fuera de Cuba, y moldeada por el gran caos que caracteriza a la década de los noventa, posee un carácter innovador. La producción literaria de esta época muestra una serie de características nunca antes vistas en la literatura de las décadas anteriores, ni siquiera antes del período revolucionario que comienza en 1959. Los factores políticos y socioeconómicos que hasta el momento se han comentado son de innegable inspiración para los autores finiseculares. El entorno actúa como elemento transformador en la visión que el intelectual tiene de sí mismo dentro de lo que queda del proceso revolucionario. El autor por su parte se convierte en lo que Georg Lukács define como "el individuo [que] se reduce a no ser sino un instrumento cuya situación central depende exclusivamente de su aptitud para revelar una cierta problemática del mundo"15. Y, según Lukács, para que el escritor capte la vitalidad de las fuerzas sociales de su entorno, es necesario que las viva como realidades concretas y no como meras abstracciones inertes (cit. en Navajas 70). Es decir, que el autor está en estrecho contacto con su entorno social, incluso cuando ya se ha sumergido en el proceso creativo. Es por eso que la narrativa cubana de este período deja de estar incondicionalmente comprometida con ese proceso revolucionario, y sobre tal

\footnotetext{
${ }^{15}$ A pesar de su relación con la crítica marxista, y de sus innegables contribuciones a la misma, Lukács criticaba la predisposición del realismo socialista a la crudeza, a presentar personajes estereotipados y al estilo de reportaje del realismo socialista y del naturalismo. De hecho, durante los años treinta, Lukács se vio involucrado en un intenso debate con diversos miembros del partido comunista. Para ellos, la literatura era un instrumento en manos del proletariado, que había de usarse para la organización y la educación de las masas, bajo las directivas del partido comunista. Para Lukács, sin embargo, la literatura era un instrumento que permitía la comprensión de los procesos histórico-sociales, revelando a la vez sus causalidades y contradicciones. Lukács es uno de los defensores del realismo crítico y uno de los más vehementes críticos del realismo socialista (cit. en Tavor Bannet 476).
} 
compromiso adquieren prioridad las preocupaciones humanas, filosóficas y estéticas del autor. En la literatura finisecular cubana, fruto de las condiciones del Período Especial en Tiempos de Paz, se observan irreverentes y provocadoras formas de expresión, nuevas y variadas temáticas que reflejan la complejidad de la realidad del momento y un renovado pensamiento crítico. Todos estos aspectos dan validez a la aproximación sociológica de Lukács a la literatura, aproximación que, según Birger Angvik, tiene mucho en común con la teoría de la novela de Mario Vargas Llosa. Para Vargas Llosa, indica Angvik, “explicar el texto significa explicarlo desde el punto de vista de las ideas, estado psicológico o antecedentes sociales del autor; significa buscar los 'demonios' implantados en el texto" $(21)^{16}$.

Las nuevas formas de expresión, que incluyen ciertas manifestaciones tremendistas y aspectos del realismo sucio, se estudiarán a través de textos como El Rey de La Habana y Trilogía sucia de la Habana de Pedro Juan Gutiérrez, Adiós a las almas de Jorge Alberto Aguiar Díaz y Los hijos que nadie quiso de Ángel Santiesteban. Por otra parte, se explorarán las temáticas recurrentes en la novela de este período, el hambre, el exilio y la nostalgia mediante el análisis de obras como El hombre, la hembra y el hambre de Daína Chaviano, Café Nostalgia de Zoé Valdés y Los palacios distantes de Abilio Estévez. Por último, se analizará el resurgimiento del pensamiento crítico en la literatura que se presenta a través del revisionismo histórico de Leonardo Padura Fuentes

\footnotetext{
${ }^{16}$ Angvik señala que Vargas Llosa tiene una visión sociológica de la obra literaria similar a la de Lukács en varios sentidos: Primero que ambos consideran que la tarea del autor es dejar fluir sus experiencias personales en el texto, y segundo, que no debe encauzarlas de acuerdo con ningún precepto moral ni ideológico. Por otra parte Angvik indica que tanto Lukács como Vargas Llosa creen que una forma correcta debe "reflejar la realidad de la manera más objetiva" (27). Tal objetividad implica que el autor ha de presentar una visión crítica y no utópica de la realidad que le rodea.
} 
en La novela de mi vida, y del cuestionamiento del proyecto revolucionario en El vuelo del gato de Abel Prieto y en Las palabras perdidas de Jesús Díaz.

El estudio de los diferentes aspectos que se mencionan anteriormente matizará la tesis de este trabajo: la caída del ideal del Hombre Nuevo. Tanto las formas de expresión, como las temáticas recurrentes y el pensamiento crítico que se hacen evidentes en los textos que ocupan los próximos tres capítulos de este estudio, constituyen una clara muestra de la función del entorno social en la creación literaria, al igual que del papel que desempeña la literatura como reacción a dicho entorno. Por otra parte, la tesis de la caída del ideal del Hombre Nuevo que se perfila en los textos en cuestión conduce a una interrogante que permanece irresuelta: ¿Cuáles son las repercusiones de la caída de este ideal? Habría que preguntarse quién o qué ha venido a suplantar al Hombre Nuevo, algo que sólo podría hacerse a través de una reflexión especulativa que, lejos de hacer una predicción, intentaría simplemente proponer posibles modelos para una nueva filosofía de vida o para un nuevo ideal. 


\section{Capítulo II}

Nuevas formas de expresión en la narrativa del Periodo Especial:

Imagen y voz del entorno

Una de las tendencias que se pueden observar en la narrativa de la última década del siglo XX en Cuba, en especial aquélla que resulta de los cambios que se suscitan durante el llamado Periodo Especial, es el surgimiento de nuevas formas de expresión. Estos cambios en el lenguaje literario responden sobre todo al viraje que se produce dentro de la sociedad cubana de la época. En una sociedad donde las delimitaciones entre las clases sociales desaparecen, y donde el diario vivir se centra únicamente en la subsistencia del individuo, el lenguaje popular y la jerga predominan sobre el lenguaje culto, académico, e incluso el lenguaje revolucionario.

La crisis y el desencanto popular producen un relajamiento en el lenguaje que refleja el nuevo modus vivendi, la nueva realidad circundante. Éstos sólo pueden ser expuestos a plenitud en la literatura del momento a través de un lenguaje provocador, subversivo y transgresor. Pero no se trata de un lenguaje de abierta protesta social o política, sino de técnicas que, aunque más sutiles, crean la actitud y el desasosiego necesarios en el lector para que éste se sitúe en medio de la realidad que el autor desea o necesita exponer. En este capítulo se abordarán textos de los autores cubanos Pedro Juan Gutiérrez, Jorge Alberto Aguiar Díaz y Ángel Santiesteban, quienes se han dado a la tarea de plasmar en sus páginas una realidad hasta el momento indescriptible en la literatura de la revolución. Recuérdese que, como se explica en el capítulo anterior, desde el comienzo de la época revolucionaria hasta la década del noventa, el texto, literario o no, debe acatar las estrictas reglas de censura establecidas por el gobierno. Como se verá, 
estos autores, lejos de respetar tales reglas, optan por la transgresión y el desacato literarios.

En este capítulo se estudiarán dos tendencias principales: el tremendismo, en especial aquél adjudicado al escritor español Camilo José Cela; y el realismo sucio norteamericano o Dirty Realism, teniendo en cuenta la influencia que sobre este movimiento han tenido otros de la literatura norteamericana como la generación perdida y la generación Beat. El objetivo que persigue este capítulo es demostrar la relación que existe entre el entorno y el lenguaje que caracteriza la literatura del momento y el sitio en cuestión. Es decir, así como el tremendismo de Cela es una especie de reacción y reflejo ante la situación que se vivía en la España de la posguerra, y así como las diferentes corrientes literarias tales como la generación perdida, la generación Beat y el Dirty Realism norteamericano, responden a los cambios que continuamente se han producido en esa nación (la reacción a la postguerra mundial y la guerra fría entre otros), el lenguaje de la narrativa finisecular cubana constituye la imagen y la voz de la compleja realidad que sus autores pretenden plasmar en sus textos.

\section{Manifestaciones tremendistas en El Rey de La Habana a partir de La familia de}

\section{Pascual Duarte}

Escrita en 1942, en plena época de la posguerra española, La Familia de Pascual Duarte pertenece a un período de gran aislamiento cultural y político en España, una época de censura, tanto política como religiosa. El resultado en el ámbito literario, al menos en el caso de Camilo José Cela, es la creación de una literatura que desde el principio recibe el sello de tremendista, una literatura inquietante, cargada de angustia existencial y de cinismo, dos elementos recurrentes en los tiempos críticos y traumáticos 
de una nación. La estrecha relación entre sociedad y literatura parte de que las angustias personales que se perfilan en una obra no son sino metáforas de situaciones sociales palpables. Dos aspectos de la tendencia tremendista que ventilará este estudio son los que Francis Donahue llama "emphatic realism" y "the new philosophical orientation". El realismo enfático es, según Donahue, "an attempt at securing an objective portrayal of life, mainly in its bitter, violent, negative, anguish-producing aspects" (305) ${ }^{1}$. La predilección por plasmar lo grotesco, lo violento y lo sucio en un mundo ficticio se convierte en una vía factible para reflejar el estado real de la sociedad en cuestión, aquello que preocupa y hasta aterroriza al autor y, por ende, al lector.

Es precisamente en circunstancias similares de amargura, violencia y angustia que situamos la novela El Rey de La Habana (1999) de Pedro Juan Gutiérrez. Esta novela retrata la sociedad finisecular cubana, el momento en que las vicisitudes económicas, el desencanto popular y la desesperanza alcanzan su máxima medida. La obra es una suerte de visión inédita de la vida cotidiana de La Habana contemporánea, muy distinta a aquélla que se perfila en los folletos turísticos y la propaganda gubernamental, cuyo objetivo es resaltar la riqueza histórica, arquitectónica y natural de la isla, así como los logros de la revolución. Al contrario, La Habana de Pedro Juan Gutiérrez es una ciudad hambrienta y sucia, donde vive la gente más pobre y marginal: mendigos, borrachos, prostitutas, pícaros, gente que está siempre entre la vida y la muerte por sus oscuros estilos de vida y por la agobiante hambruna. No es mera coincidencia que durante este período se produzca en Cuba una nueva narrativa irreverente y cruel que retrata la

\footnotetext{
${ }^{1}$ Donahue explica su concepto de emphatic realism al decir que "It is the natural outgrowth of a period of civil war, followed by great human dislocation, disillusion, fear and guilt, and the psychological gnawing of the memory of scenes of great brutality" (305).
} 
realidad social sin tapujos ni rodeos. Pedro Juan Gutiérrez es uno de los más vivos ejemplos de esa manera tremendista, insolente y cruda de escribir. Y por lo tanto el lenguaje, las experiencias humanas y las imágenes en El Rey de La Habana muestran innegables similitudes con la escritura tremendista de Camilo José Cela en La familia de Pascual Duarte.

La época del franquismo en España, período dictatorial de fuerte represión, produce las condiciones necesarias para la creación tremendista de Cela. Asimismo, la época del llamando Periodo Especial en Tiempos de Paz, quizá la época más asfixiante del castrismo en Cuba, ha servido de trágica inspiración para Gutiérrez, ya que ambas novelas son el producto de una sociedad donde impera la censura que conlleva a la vez una imperiosa necesidad de denuncia. En ambos autores se pone de manifiesto un realismo tremendista en el que lo obsceno, lo repulsivo y lo escatológico priman sobre cualquier otro estilo narrativo. Las manifestaciones tremendistas en los textos que aquí se estudian ofrecen una voz de protesta social a autores censurados y autocensurados como Cela y Gutiérrez ${ }^{2}$. No obstante, algunos elementos contrastan entre las novelas que aquí nos ocupan. Por ejemplo, la vida de Pascual Duarte se desarrolla mayormente en una zona remota, en "un pueblo perdido por la provincia de Badajoz; [. . . a unas dos leguas de Almendralejo, agachado sobre una carretera lisa y larga como un día sin pan..." (26). Es un sitio marginado del mundo, social y geográficamente. Además, la vida del personaje transcurre en épocas tempranas del siglo XX. En un extremo diametralmente opuesto está Reynaldo, el personaje principal de El Rey de La Habana. La vida de este

\footnotetext{
2 Tanto El Rey de La Habana como La familia de Pascual Duarte fueron publicadas fuera de Cuba y España respectivamente. El propio Gutiérrez plantea el problema de la censura cuando dice: "Incluso una editorial cubana [...] acaba de leerse El Rey de La Habana a espaldas mías, sin contar conmigo [...]. Yo tengo amigos que me han dicho: 'Han decidido no publicar El Rey de La Habana"' (Clark 6).
} 
joven transcurre en su mayor parte en uno de los paupérrimos barrios de La Habana finisecular. Es decir, que tanto espacial como temporalmente, ambos escenarios representan extremos opuestos. No obstante, muy a pesar de los contrastes, y tal vez precisamente a causa de ellos, El Rey de La Habana y La familia de Pascual Duarte comparten elementos que ilustran la relación entre literatura y sociedad. Y en el proceso de establecer dicha relación, Cela y Gutiérrez muestran una capacidad para sorprender y provocar al lector, que nace con la necesidad de épater le bourgeois ${ }^{3}$. Para Gutiérrez, esa necesidad se convierte en el "placer sádico del escritor. Golpear sorpresivamente"(1) 4 El lector, afirma Gutiérrez, es un lector pesimista que quiere "sentir el gusto ansioso de recibir el latigazo en su piel" (1).

Uno de los elementos fundamentales es la ironía de ambos títulos. En el texto de Cela, la ironía del título radica precisamente en que la familia de Pascual no es sino un ente ausente. La ausencia de una familia unida y amorosa rige y moldea la vida del personaje principal. Pero no se trata de una ausencia física de los familiares, sino de su rechazo y desamor hacia Pascual. Por su parte, el rechazo y la frustración familiar, seguidos de actos criminales, constituyen una constante en la novela (Valle 6). La ironía en El Rey de La Habana se observa en el hecho de que "Rey" es la abreviación del nombre del personaje principal Reynaldo, quien, lejos de ser una figura real, está completamente marginado por una sociedad que, a su vez, se encuentra al margen del mundo. Rey no logra incorporarse a ningún círculo social, ni siquiera a los más bajos y

\footnotetext{
${ }^{3}$ Según Lucile C. Charlebois, el objetivo de épater le bourgeois se desarrolla en las tempranas etapas del movimiento de Vanguardia, por el interés de artistas y escritores en provocar y sorprender al público burgués (8).

${ }^{4}$ El golpe sorpresivo al que se refiere Pedro Juan Gutiérrez va dirigido a un lector burgués representado tanto por la cultura oficial cubana, como por el desinformado e ingenuo lector extranjero.
} 
degradados. Él representa el antihéroe marginal al que se refiere Nelson González Ortega en un estudio sobre la novela de finales del siglo XX, donde comenta la "presencia de discursos marginales, en los cuales se incorporan temáticas del género sexual y se introducen personajes 'antiheroicos', marginales y degradados, provenientes de grupos que no tienen poder en la sociedad" (208). Se podrá observar que tanto Pascual como Rey son dos entes completamente enajenados dentro de sus respectivos mundos y que, por lo tanto, viven una vida grotesca y violenta, que sólo puede llevar a un trágico final.

Desde el principio de la historia, Pascual describe su entorno familiar, reflejando en esa descripción un mundo grotesco. Describe su casa como un sitio donde "lo único que se podía ver era la cocina" (28). Cuando hace referencia al resto del hogar se puede apreciar su ambiente desagradable: "El resto de la casa no merece la pena ni describirlo, tal era su vulgaridad" (29). Dentro de la descripción de la vivienda, se produce una especie de deformación burlesca de la cuadra, donde se observa el tremendismo de Cela en máxima expresión; es decir, su predilección por escandalizar y provocar al lector: "La cuadra era lo peor. Era lóbrega y oscura y en sus paredes estaba empapado el mismo olor a bestia muerta que desprendía el despeñadero cuando allá por el mes de mayo comenzaban los animales a criar la carroña que los cuervos habíanse de comer" (30). Obsérvese que, desde el principio tan sólo en la descripción de la vivienda ya se hace presente el elemento de la muerte, sobre todo a través de la poderosa imagen de los cuervos devorando la carroña. Además del aspecto físico de la casa y sus alrededores, es necesario prestar atención al ambiente familiar, del que Pascual guarda recuerdos grotescos y violentos. Todos los miembros de la familia de Pascual aparecen como figuras distorsionadas, casi esperpénticas. De su padre, Pascual recuerda las palizas que 
éste le propiciaba a él y a su madre: "Cuando Rosario nació se arrimó hasta la cama de mi madre y sin consideración ninguna de la circunstancia, la empezó a llamar bribona y zorra y a arrearle tan fuertes hebillazos que extrañado estoy todavía de que no la haya molido viva" (42). Todo es repulsivo en el recuerdo del padre, incluso su muerte. El padre muere días después de ser mordido por un perro rabioso, momento tras el cual es necesario encerrarlo para proteger a la familia y a los vecinos de sus patadas y mordidas. La descripción del cadáver es una de las más espeluznantes de la novela: “[Y] no tuve más remedio que tragarme las lágrimas que quisieron asomarme cuando vi el cadáver que tenía los ojos abiertos y llenos de sangre y la boca entreabierta con la lengua morada medio fuera" (55). La escena se torna aún más absurda con la risa incontrolable de la madre al ver el cadáver.

Las imágenes repulsivas de la familia no siempre son señal de desprecio. El caso de Rosario y Mario demuestra que Pascual siente una inmensa compasión por sus hermanos, pues los ve a ambos como entes deshumanizados, como animalillos acorralados y desamparados, a merced de una madre despiadada. Rosario, recién llegada al mundo, aparece como un bulto sanguinolento y deforme envuelto en las mismas tiras de algodón por varios días. Mario, por su parte, es una criatura que nunca aprende a hablar ni a caminar; es decir, que nunca llega a trascender al nivel humano. Pascual afirma que "no pasó de arrastrarse por el suelo como si fuese una culebra y hacer unos ruidos con la garganta y con la nariz como si fuese una rata" (50). La imagen grotesca de Mario se acentúa cuando Pascual habla del sarpullido que le afecta el trasero. Explica que “llegó a ponerle las nalguitas como desolladas y en carne viva por habérseles mezclado la orina con la pus de las bubas" (57). Cabe destacar, sin embargo, que Pascual siente 
compasión por su hermano, y que si bien todas estas descripciones de los miembros de la familia revelan la predilección de Cela por ofrecer imágenes grotescas de la realidad de esa infancia, éstas casi siempre son provocadas por las experiencias vividas en esa etapa de su vida. La importancia de esta imagen deshumanizada de la familia radica precisamente en el papel que ésta juega en el devenir de la vida de Pascual. La familia crea, en la infancia de Pascual, un ambiente destructor y opresor. Así lo afirma ZamoraVicente al describir la infancia de Pascual como "un clima de negra desolación, donde el azar, la violencia [y] la falta total de normas son las únicas guías de la existencia” (32).

La teoría de Zamora-Vicente sobre el papel de la familia en la infancia de Pascual también cobra validez cuando se toma en cuenta la problemática infancia de Reynaldo. La familia de Rey está compuesta por la abuela, la madre y el hermano mayor. Ésta es una familia en la cual reinan un desamparo y una violencia aterrantes. Viven "todos en un cuarto derruido de tres por cuatro metros, y un pedazo de azotea al aire libre. Aquel pedazo de azotea era el más puerco de todo el edificio" (9-10). Tal vez el personaje más deshumanizado de la familia sea la abuela, quizá porque ella es la propia imagen de la muerte, de un ser que ha dejado de existir: "La vieja llevaba años sin bañarse. Muy flaca de tanta hambre. Una vida larguísima de hambre y miseria permanente. Estaba encartonada. No hablaba. Parecía una momia silenciosa, esquelética, cubierta de suciedad. Se movía poco o nada. Sin hablar jamás" (10). Esa presencia casi ausente de la abuela no parece inspirar ningún tipo de sentimiento en Rey, sino que su figura es una premonición de la nada, de la no-existencia a la que sin duda llegará esta familia.

La madre de Rey, por su parte, es un personaje que provoca repulsión y odio, como la de Pascual, sólo que además inspira compasión. Es una mujer violenta, pero a la 
vez medio retardada, y la miseria ha destruido su existencia. Una de las descripciones más deshumanizadoras de la madre se observa en la siguiente frase: "Ahora ya estaba medio viejuca, monga, apestosa a rayo, coja de una pata, muriéndose de hambre" (10). Sin empleo y abandonada por el padre de sus hijos, ella personifica la amargura de una vida frustrada, carente de toda ilusión. La frustración y la desesperanza de esta mujer frente a la vida que le ha tocado vivir se ponen de manifiesto en el trato hacia sus hijos, en especial en la manera de disciplinarlos: "Desde pequeños hasta que tuvieron siete años, los metía en aquel lugar húmedo, llenos de tuberías y cucarachas. Sin razón. Sólo por alejarlos de la vista [...]. Otras veces los zambullía de golpe en un tanque de agua [. . .]. A veces los hundía en el agua y no los sacaba hasta que medio asfixiados pataleaban desesperados" (10-11).

Se trata, sin embargo, de una violencia recíproca. Al igual que la madre de Pascual frente a las palizas del padre, los hijos retribuyen sin contemplaciones las golpizas de la madre. $\mathrm{Y}$ es que la violencia juega un papel clave en la vida de estas personas, sobre todo en la infancia de Nelson y Rey, niños de hoy, hombres del futuro, para quienes tal futuro no es siquiera una remota posibilidad. Como Pascual, Rey arrastrará la violencia de su infancia hacia su corta vida de adulto. La inclinación de Gutiérrez hacia una imagen de violencia en el entorno del personaje central radica en que "la violencia es quizás un esfuerzo profundo del inconsciente colectivo por conjurar una amenaza que pesa sobre el hombre contemporáneo" (Lapuente 165). La violencia entre los personajes ficticios del texto es la única manera de exteriorizar la impotencia y la ira frente a la crudeza del entorno. A medida que transcurre el tiempo, la madre de Rey continúa perdiendo sus facultades mentales, y son los niños quienes asumen el control de 
la situación doméstica. La madre comienza a deshumanizarse paulatinamente como la abuela, hasta perder completamente las riendas de la familia: "También tenían que controlar a su madre porque cada día era más estúpida. Ya ni atinaba a bajar las escaleras. La empujaban y le gritaban para que se callara, pero ella berreaba más aún, agarraba un palo y les entraba a palo limpio. Ellos [. . . la reducían con unos bofetones en pleno rostro" (13). Es decir, que la violencia que se desata en la vida familiar de Rey no es sino un preámbulo a la violencia social a la cual tendrá que enfrentarse el personaje, cosa que hará precisamente con la única arma a la que tiene acceso: la violencia.

Nelson, hermano de Rey, es un adolescente impulsivo y desobediente que no siente el más mínimo respeto por su madre. Y esa actitud produce el suceso que cambiará su vida y la de Rey para siempre. Durante una violenta discusión, Nelson y su madre forcejean, pero la madre pierde el equilibrio y queda ensartada por una cabilla de metal que sale del gallinero. La muerte de la madre de Rey es tan grotesca como la del padre de Pascual: "La mujer no grita. Abre los ojos con horror, se lleva las manos al lugar por donde entró el acero. Y muere aterrada. En segundos se forma un charco de sangre espesa y de líquidos viscosos. Muere con los ojos abiertos, horrorizada" (15). La situación se torna aun más trágica cuando Nelson, al ver a su madre muerta, se lanza de la azotea y cae muerto en la calle. Es evidente que el tema de la muerte violenta narrada a través de imágenes esperpénticas es de suma importancia tanto para Gutiérrez como para Cela. En ambos autores se observa una marcada predilección por el placer de la morbosidad. La violencia doméstica va a sentar las pautas para la fatalidad que persigue a Rey a lo largo de la novela y de su corta vida. Rey sufre también de esa incapacidad para expresar sus emociones e ideas y por eso guarda silencio cuando lo interrogan las autoridades. Tres 
años le esperan en un centro correccional, del cual escapa sólo para retomar su vida de violencia y marginalidad.

La incapacidad de expresión de la que padecen Rey y Pascual desempeña un papel fundamental en la manera en que ellos enfrentan las vicisitudes y afrentas. En el caso de Pascual, Germán Gullón afirma que éste "parece incapaz de defenderse con la palabra; quizás un poquito de labia le hubiera permitido responder al Estirao o a su madre, y evitar las consiguientes acciones criminales" (4). Sin embargo, Pascual tiene una necesidad imperiosa y constante de reafirmar su virilidad. Para él el asunto de la honra es fundamental. Así lo reitera Carlos Jerez-Farrán al decir que "gran parte de los actos homicidas en que incurre Pascual son atribuibles a una mórbida susceptibilidad viril que lo empuja a la violencia cada vez que la afrenta tiene que ver, o cree él que tiene que ver con su orgullo de hombre" (47-48). Recordemos que el ataque a Zacarías, donde éste recibe tres navajazos, se debe a que le ha dicho a Pascual: "Poco hombre me pareces tú para lo mucho que amenazas" (92). En ese episodio la virilidad de Pascual se pone en duda, y lo que es peor, en público. Para Pascual, la única respuesta posible a tal afrenta pública es la violencia física, el castigo corporal del agresor. Asimismo, la muerte del Estirao se produce no sólo porque la honra de Pascual ha sido mancillada, sino porque su virilidad ha sido puesta en tela de juicio.

Como ya es sabido, Pascual regresa a su casa luego de dos años de ausencia para enterarse de que Lola está esperando un hijo de otro hombre. Es evidente que Pascual está más preocupado de que su reputación quede mancillada con tal embarazo, que por la infidelidad misma de Lola. Es capaz de olvidar el desliz con tal de que no haya prueba del mismo. De modo que cuando va a buscar al Estirao está dispuesto a perdonarle la 
vida para cumplir su promesa a Lola. No obstante, cuando el Estirao, el pecho atrapado bajo la rodilla de Pascual, dice: "Entonces me quería", Pascual sufre una vejación que él considera "demasiada chulería", y allí mismo lo asesina (149). Paul Ilie explica que la integridad masculina se convierte en lo más preciado para individuos de la clase y el temperamento primitivos de Pascual: "Puesto que tienen escasa capacidad para las abstracciones, no poseen habilidades técnicas o logros profesionales y no pueden jactarse del prestigio social o posición económica, tales hombres no tienen nada de qué enorgullecerse como no sea de sus proezas físicas" (51).

La obsesión de Pascual por reafirmar su hombría es una constante que se repite en el personaje de Reynaldo. Cuando comienza la historia, Rey sólo tiene trece años, y los tres años que permanece encerrado en el centro correccional son para él una dura prueba. Durante ese tiempo vive constantemente preocupado por defender su honra y demostrar que no es homosexual. Luego de un violento altercado con otro prisionero que trata de violarlo, Rey toma las precauciones que cree necesarias para que no se repita el incidente: "Le sacó punta y filo a un cepillo de dientes... con eso podía taladrarle el corazón al que viniera a abusar. Tenía ganas de metérselo al negro y escarbarle bien hasta cortarle todas las venas y desangrarlo. Le tenía odio. Creyó que era maricón... Nada de eso. Él era un tipo durísimo" (19). Pero la preocupación por demostrar su hombría a toda costa no se limita al tema de la sexualidad. Desde pequeño escucha decir a su madre que los hombres no lloran. Sin embargo, a raíz de su fuga del reformatorio, en un momento en que ve su antigua azotea desde la distancia, comienza a llorar inconsolablemente. Esto para Rey es una debilidad imperdonable y por eso se golpea la cara y la cabeza con una piedra para no volver a sucumbir a la tentación, y luego se promete a sí mismo: "Para la próxima le 
entro a cabezazos a una pared y me mato" (37). Rey está convencido de que los hombres "no se pueden aflojar. Los hombres tienen que ser duros a morirse" (37). Es evidente que Rey, un individuo tan primitivo como Pascual, pertenece a la categoría descrita por Paul Ilie, y que para él la única cualidad estimable en un hombre es la masculinidad.

Para Rey, la sexualidad es la única vía para afirmar su hombría, ya que, como indica Ilie, es un hombre que carece de cualquier otro motivo de orgullo. Al salir del reformatorio ya tiene dieciséis años, y su apetito sexual es insaciable. En su constante deambular por las ruinosas calles de La Habana percibe los deseos sexuales que provoca en las mujeres que encuentra a su paso, y no duda en tener encuentros sexuales con ellas, aun sin conocerlas. La promiscuidad de Rey está relacionada, entre otras cosas, con el hecho de que la revolución atea trajo consigo una especie de liberación sexual en la población, acentuada por la falta de privacidad provocada para la escasez de vivienda. Además, en un mundo donde la preocupación fundamental es el hambre, donde nadie tiene energías para pelearse ni para protestar, el sexo es la vía de escape más asequible e inmediata. Como ha notado Athena Alchazidu, "[E]n la narrativa de los noventa vuelve a prevalecer una visión pesimista del mundo, dominado por la crueldad. El sexo y la violencia son los elementos más importantes [ . . ] junto con el tercer componente de la tríada que representa el motor del vehículo tremendista: el hambre" (101). En la novela de Pedro Juan Gutiérrez, la sexualidad exenta de toda poesía es una metáfora del resquebrajamiento de las relaciones humanas dentro de la sociedad que el autor retrata en el texto. Como afirma Rafael Rojas, refiriéndose a la narrativa cubana finisecular, "[L]a política del cuerpo es aquélla que propone sexualidades y erotismos, morbos y escatologías como prácticas liberadoras del sujeto" (45). 
Es en el acto sexual, y sólo en él, que tanto el hombre como la mujer alcanzan una libertad absoluta de expresión. Pero para que tal encuentro sea verdaderamente liberador, tiene que ocurrir en un entorno escatológico, y debe ser presentado sin ningún tipo de afeites. Por eso, el elemento fundamental de las relaciones sexuales de Rey, lejos del erotismo en sí, es la manera deshumanizada e irreverente con que el narrador las describe. No se trata de relaciones romantizadas ni idealizadas, sino que ocurren entre cuerpos hediondos y sucios, y se describen con una crudeza en el lenguaje sexual cuya función subversiva es patente. El siguiente es uno de los tantos encuentros sexuales entre Rey y Magda, que Gutiérrez describe con exacta crudeza a través de la novela. "Y templaron como dos salvajes, amándose como nunca les había sucedido, orgasmo tras orgasmo hasta el amanecer. Entonces se quedaron dormidos, así, bien puercos, embarrados de sudor y semen y mugre y hollín. Durmieron como dos marranos felices sobre aquel jergón asqueroso" (119).

Para Rey, su pene erecto es la única arma que posee para darse su lugar en el mundo, para incorporarse a una sociedad marginada que a la vez se empeña en enajenarlo. Un encuentro sexual que revela una cruda ironía es el que ocurre con Sandra, el travestí homosexual. Rey sabe que Sandra es un hombre, pero no le importa tener relaciones con él porque su papel es el de penetrador. No le es nada difícil voltear la cara para no ver la erección de Sandra. El acto sexual cumple con la simple función de poseer algo verdaderamente, de poseer al otro, sea hombre o mujer. En este respecto, Rojas insiste en que el establecimiento de la identidad homosexual en el caso de la sociedad cubana tiene claras implicaciones subversivas, ya que tal comportamiento no corresponde con la establecida moral revolucionaria (45). En la narrativa producida durante la época 
de la revolución cubana, el tema de la homosexualidad queda excluido, con la excepción del conocido capítulo ocho de Paradiso, como se ha mencionado en el capítulo anterior. Pero en la época del Periodo Especial, la homosexualidad es una realidad demasiado obvia como para esconderla o tapizarla, sobre todo en una novela cuya función principal es retratar la sociedad, mostrarla tal cual es, sin tapujos ni disimulos.

En La Familia de Pascual Duarte, el elemento central no es la sexualidad. De los tres elementos tremendistas que presenta Alchazidu (sexo, violencia y hambre), la violencia física tiene precedencia en el caso de Pascual. Pero tanto en los encuentros sexuales de Rey como en las agresiones de Pascual, se observa una delectación en lo morboso, lo repulsivo y lo escatológico. En Pascual, se reafirma la hombría a través de actos violentos, no sólo con los humanos, sino también con los animales. Sabemos que Pascual mata a la perra Chispa y a la yegua que desmonta a Lola provocándole un aborto. Sabemos además que hiere de tres navajazos a Zacarías y que mata al Estirao aplastándole el pecho con su rodilla. Todas estas escenas son tan grotescas como los encuentros sexuales de Rey, pero Cela y Gutiérrez alcanzan la máxima representación de lo grotesco en los asesinatos de la madre de Pascual y de Magda, respectivamente ${ }^{5}$. La similitud entre las dos muertes radica en que éstas representan el momento en que ambos personajes, ya situados al borde del precipicio, caen para siempre en el abismo de la perdición, firmando sus propias sentencias de muerte con la sangre de sus víctimas. Sólo mediante escenas de un horror y una repulsión insuperables logran ambos autores plasmar la tragedia del momento en el que Pascual y Rey se pierden para siempre.

\footnotetext{
${ }^{5}$ Magda (Magdalena) es la vendedora de maní y jinetera que recoge a Rey en la calle y le ofrece albergue en su cuartucho en la azotea de un edificio habanero en ruinas. El edificio termina por derrumbarse, y ambos se ven obligados a salir huyendo, quedando desamparados.
} 
El efecto que estas descripciones tienen en el lector es muy similar en las dos novelas. Se trata de un proceso que Robert Kirsner describe al incorporar la función del lector en estas imágenes: "The reader is wounded not so much by the atrocities committed by a deranged character as by his own inability to grasp the impurity of feeling that such incidents create" (60). A pesar de lo violento de sus crímenes, al lector se le imposibilita experimentar el repudio total del personaje, lo cual es aún más aterrador. Sin embargo, éste parece ser el objetivo de Cela y Gutiérrez, ya que a través de sus técnicas tremendistas logran situar al lector en medio de la realidad del personaje. Por lo tanto, surge una suerte de complicidad del lector, quien reconoce que los crímenes cometidos están, de cierta manera, justificados. Refiriéndose a Pascual, Francis Donahue insiste en que éste no es sino una especie de víctima de las circunstancias cuya tragedia es no encontrar otra opción que ser un criminal reincidente: "It takes the reader some time to realize that Pascual is a better person than his victims, and that his criminal forrays constitute a type of abstract, barbarous but undeniable justice..." (302). Es decir, que los crímenes representan una reacción contra la familia y contra la sociedad. Si se aplicara el mismo razonamiento al personaje de Rey, habría que decir que Rey, un joven de dieciséis años con tal historial de violencia y muerte en su familia, totalmente desamparado y marginado, carece de toda noción de moral, autocontrol o compasión, y que, por ende, no es responsable de sus acciones.

La escena del asesinato de la madre de Pascual sitúa al lector al borde de la cama donde está ocurriendo el matricidio: "Rugíamos como bestias, la baba nos asomaba a la boca... La condenada tenía más fuerzas que un demonio [. . . ]. Hubo un momento en que con la boca me cazó un pezón [. . .] y me lo arrancó de cuajo. Fue el momento mismo en 
que pude clavarle la hoja en la garganta" (178-79). El carácter violento de la madre, presente en todo el texto, se prolonga hasta el momento de su muerte y por eso en esta escena ambos personajes desempeñan un papel activo. Es decir, que Cela no habría cumplido con su objetivo de deshumanizar a la figura de la madre si ésta no hubiese luchado por defenderse del agresor, como cualquier animal acorralado. Si hubiese muerto sin poner resistencia, entonces se le habría acordado el papel de víctima, algo que Cela no puede hacer si quiere señalar a la madre como la culpable (si bien no la única) de la vida que ha tenido su hijo. Presenta a la madre como una fiera a lo largo de la novela y como tal la muestra en el momento de su muerte.

El asesinato de Magda, asimismo, es el resultado del resentimiento de Rey contra la mujer que cuestiona su virilidad. Durante la corta relación entre ambos, Rey es consciente de que Magda se prostituye, pero ella insiste en que no disfruta de sus encuentros sexuales porque los considera simples actos de canje. Sin embargo, la noche del crimen, noche en que Magda regresa al improvisado hogar con ropa y comida, no ha estado con un cliente sino con un antiguo amante, el padre de su hijo. Frente a tal afrenta Rey enloquece y le corta el rostro con un cuchillo: "Una herida tan profunda, que se le veían los huesos, los tendones, los dientes. Le gustó verla así, desfigurada, con el rostro rajado y la sangre corriendo por el cuello abajo" (212). Magda, sin embargo, en lugar de asumir un papel de víctima, continúa insultándolo, provocándolo mientras le asegura que su amante sí es un hombre de verdad, y parada frente a él, espera el golpe mortal: "Rey, ya sin control, le asestó otro tajazo por el cuello. Le cortó la carótida" (212). Nótese que Pascual y Rey no sólo utilizan el mismo método para matar a sus víctimas, sino que la imagen de la sangre caliente saliendo a borbotones, empapando a la víctima y al 
victimario, está presente en ambos casos. La gran diferencia entre las dos muertes, empero, es que para Pascual la muerte de la madre es una experiencia liberadora: "El campo estaba fresco y una sensación como de alivio me corrió por las venas. Podía respirar" (179). Para Rey, en cambio, la muerte de Magda no lo es. Así se observa cuando en el instante en que muere la mujer, se acuesta sobre ella y la penetra, eyaculando rápidamente, buscando en vano el alivio que la muerte de Magda no le ha producido. Magda muere porque destruye la hombría de Rey, pero su muerte no lo libera, y tampoco lo satisface la penetración del cadáver. Tal penetración es un intento fallido de recuperar su virilidad arrebatada, ahora definitivamente perdida. A través del aspecto necrófilo de la escena, Gutiérrez alcanza el nivel más grotesco de la novela, precisamente porque presenta el momento en que Rey pierde el minúsculo vestigio de humanidad que alguna vez pudo haber en él.

Pascual y Reynaldo son dos personajes tan complejos como sus respectivos entornos familiares y sociales. Las similitudes entre ellos van más allá de sus acciones. Sus perspectivas frente a la vida reflejan el sentir de una o varias generaciones en sociedades donde la represión y la censura forman parte del modus vivendi. Algunos aspectos de la filosofía existencialista, como la abulia, la angustia existencial, y la desesperanza también forman parte de la literatura tremendista que hemos señalado hasta el momento. Para esta afirmación se retoma el segundo componente de la estética tremendista presentado por Francis Donahue: una nueva orientación filosófica relacionada con el existencialismo. Donahue opina, empero, que la orientación filosófica existencialista que se observa en la novela tremendista no se deriva precisamente del existencialismo literario francés, sino que se observa en ella la influencia de filósofos 
existencialistas españoles como Miguel de Unamuno y José Ortega y Gasset (305). Tanto Reynaldo como Pascual demuestran tener la visión trágica de la vida a la que se refiere Unamuno: "Si deshecha la ilusión de vivir, el vivir por el vivir mismo o para otros que han de morirse también no nos llena el alma, ¿para qué vivir? La muerte es nuestro remedio" (15). Pero en ellos esta visión parte a su vez de la relación entre el ser humano y su circunstancia como indica Ortega y Gasset cuando afirma: "Yo soy yo y mi circunstancia, y si no la salvo a ella no me salvo yo" (3). Sólo que, al parecer, ni Pascual ni Rey pueden hacer nada por cambiar sus respectivas circunstancias, negándoseles de ese modo toda posibilidad de salvación.

Reynaldo, por ejemplo, va por la vida como si ésta fuese un arduo e interminable viaje sin rumbo. Él es un hombre/niño sin esperanzas y sin ambiciones porque su vida carece de todo sentido. Su actitud se hace evidente cuando se escapa del reformatorio: “Aquí afuera no tengo nada que hacer y allá tampoco. ¿Pare qué nace la gente? ¿Para morirse después? Si no hay nada que hacer. No entiendo, para qué pasar todo este trabajo. Hay que vivir, batirse con los demás pa'que no te jodan y al final todo es mierda" (25). Es precisamente la actitud que mantiene a través de su corta vida, y ésta constituye además una filosofía compartida por toda una sociedad consumida por la miseria y la represión. El propio autor afirma que él ve a Rey "como un símbolo del pobre, el verdadero pobre que no tiene futuro y sencillamente se olvida de su futuro porque sabe que no tiene futuro" (cit. en Clark 8). La vida de Rey no es sino un lúgubre desfile de desgracias: el abandono del padre, la muerte de toda su familia en un mismo día, los años en el reformatorio y la miserable existencia como mendigo en las calles habaneras. 
Rey es un personaje que atrae la mala suerte, el destino adverso, aun cuando simplemente deambula por las calles tratando de subsistir. Un ejemplo de ello es el episodio en que el borracho suicida le pide que lo ayude a subir a la azotea de un edificio donde dice vivir, sólo para lanzarse a la calle frente a los ojos incrédulos de Rey. El suicidio del desconocido es una suerte de absurdo déjà vu de los hechos que tienen lugar en su propia azotea tres años antes cuando, frente a la muerte de su madre, su hermano y su abuela, enmudece y permanece inmóvil en el lugar de los hechos. Su incapacidad para expresarse y explicar lo sucedido es lo que lo incrimina y provoca su encarcelamiento. Pero esta vez, frente al cuerpo inerte del borracho, la reacción de Rey es diferente: "Sólo pensó en escapar. Temblando de miedo bajó las escaleras lo más rápido que pudo [ . . .]. Cuando llegó abajo, adoptó la expresión de tonto medio dormido que usaba para pedir limosnas [. . . . Rey se alejó Galiano arriba. Ya venían dos policías corriendo. Alguien los había llamado" (43). Rey asume la adversidad como parte de su vida, pero ahora la experiencia le indica que tiene la opción de huir.

La desesperanza y la fatalidad son también aspectos intrínsecos de la vida de Pascual. Para él, ni siquiera el buen comportamiento en la cárcel es de buen augurio porque, de no haber sido puesto en libertad por buena conducta, no habría regresado al sitio donde finalmente asesina a su madre: "Da pena pensar que las pocas veces que en esta vida se me ocurrió no portarme demasiado mal, esa fatalidad, esa mala estrella que parece como complacerse en acompañarme, torció y dispuso las cosas de forma tal que la bondad no acabó para servir a mi alma para maldita cosa” (150). Con esa conclusión de Pascual, parece coincidir Paul Ilie al afirmar que en su malograda existencia aparecen dos explicaciones más plausibles para los crímenes de Pascual. En una, Pascual es víctima de 
las circunstancias y en la otra, es víctima de su carácter impulsivo, apasionado e irracional (74). La vida de Pascual, al igual que la de Rey, es una serie de hechos lamentables, como la muerte del padre, la prostitución de la hermana, el aborto de Lola, la mísera existencia de Mario y la muerte del hijo, entre otros. La existencia de Pascual es trágica, porque trágica es su circunstancia. Se trata de un determinismo en el que el personaje queda atrapado en su propia existencia: "No son necesariamente el destino, Dios, o los impulsos los que le atrapan, sino la existencia misma. La mismedad de la existencia es, precisamente, la trama de la circunstancia" (llie 75).

La tragedia que rige las vidas de Pascual y Reynaldo actúa como preámbulo de sus muertes. Pascual muere por ejecución, pero lo más trágico no es su muerte en sí, sino la manera en que él la enfrenta. Según el informe de Cesáreo Martín, Pascual muere “escupiendo y pataleando, [ . . ] de la manera más ruin y más baja que un hombre puede terminar; demostrando a todos su miedo a la muerte" (188). En cuanto a Reynaldo, su muerte no es más que un reflejo de su vida, deshumanizada y violenta. Mientras entierra el cuerpo de Magda en un basurero, las ratas invaden el cadáver devorándolo al instante, pero él, aunque por el momento logra escapar con vida del basurero, recibe decenas de mordiscos que al final provocan su muerte: "Al fin murió. Su cuerpo ya se pudría por las ulceraciones producidas por las ratas. El cadáver se corrompió en pocas horas. Llegaron las auras tiñosas. Y lo devoraron poco a poco" (218).

Reynaldo y Pascual son personajes trágicos que viven en sociedades asfixiantes. Para Pascual, "[L]a sociedad es sencillamente otra forma de encarcelación” (Kronic 311). Para Rey, la sociedad es también el más cruel de los encierros, una suerte de laberinto donde "el ser humano queda reducido a un estado casi animal, luchando por sobrevivir en 
una selva humana donde rige la ley del más fuerte" (Clark 8). Pedro Juan Gutiérrez y Camilo José Cela plasman en sus obras, a través de las técnicas desafiantes del tremendismo, un estilo que Donahue define como "vernacular unsentimental prose" (301). Ambos autores presentan en sus textos, a través de escenas e imágenes grotescas, la tragedia que habita en las almas de estos personajes que se convierten en antihéroes, marginados y oprimidos por sus respectivas épocas y sociedades.

\section{Realismo sucio cubano: Rasgos del Dirty Realism norteamericano en los cuentos de}

\section{Pedro Juan Gutiérrez, Ángel Santiesteban y Jorge Alberto Aguiar Díaz}

Las nuevas formas de expresión de la narrativa cubana del Periodo Especial presentan, además de los aspectos de corte tremendista comentados hasta el momento, una serie de características que recuerdan ciertas etapas de la literatura norteamericana del siglo XX, modas literarias que han respondido a diversos cambios políticos y socioeconómicos en diferentes momentos de la historia de ese país. Durante los años treinta, por ejemplo, época de la posguerra y de la gran debacle económica, numerosos autores producen una literatura que responde a la crisis que se vive en esos momentos. Ésta es la época de la conocida "generación perdida", con autores como Ernest Hemingway, John Dos Passos y F. Scott Fitzgerald ${ }^{6}$. También en esta época el escritor norteamericano Henry Miller escribe, desde el extranjero, novelas como Tropic of Cancer (1934), en la que retrata la vida en el París de entreguerras ${ }^{7}$. Más tarde, en la década del cincuenta, a raíz de la segunda guerra mundial, y en pleno apogeo de la guerra fría, se produce todo

\footnotetext{
${ }^{6}$ El calificativo de "Lost Generation" lo utilizó por primera vez Gertrude Stein (1874-1946) para referirse a los intelectuales y estetas de los años que siguieron a la primera guerra mundial (Morris 863).

${ }^{7}$ Miller podría ser considerado uno de los seguidores de la filosofía de Ezra Pound, pionero de la revuelta contra el tradicionalismo literario, y miembro además de la susodicha generación perdida (Morris 864).
} 
un movimiento literario y cultural conocido como la generación Beat. Entre los autores más significativos de esta generación se encuentran Allen Ginsberg, con su controvertida obra poética Howl (1956), y Jack Kerouac, conocido sobre todo por su novela On The Road (1957). George Stephenson, estudioso de la generación Beat, explica la relación que existe entre la generación de Hemingway y Miller y la de Kerouac y Ginsberg:

The Lost Generation was divested of beliefs and ideals as a consequence of their participation in World War I or by the psychic shockwaves of that catastrophe. They felt themselves disillusioned, historically and culturally orphaned, and they rebelled against the manners and mores of their age. They explored and experimented [. . .]; and they pioneered new modes of expression. [. . .]. The Beat were a product of the Second World War and of the Cold War. They, too, rejected the social, political, religious, and artistic values of their time as outmoded and inadequate; and they, too, sought new viable ones to replace them. (4-5)

A finales de la década del setenta y durante la del ochenta se ve en el desarrollo de la literatura norteamericana una filosofía relacionada con la reacción de varios sectores de la población hacia la guerra de Vietnam, la guerra fría y otros conflictos internacionales en los que se halla envuelto los Estados Unidos. En esta época se produce gran parte de la obra de Charles Bukowski y Raymond Carver, conocidos por su relación con el Dirty Realism ${ }^{8}$. El realismo sucio norteamericano es comúnmente asociado con el

\footnotetext{
${ }^{8}$ Bill Buford utiliza el apelativo de "Dirty Realism" por primera vez a mediado de la década de los ochenta. En su definición, Buford comenta: "These are strange stories unadorned, unfurnished, low-rent tragedies. [The protagonists] drink a lot and are often in trouble: for stealing a car, breaking a window, pickpocketting a wallet..." (Granta 8: 1983).
} 
minimalismo, tendencia por la que también se conoce la obra de Ernest Hemingway. Sin embargo, como explica Mark A. R. Facknitz, el minimalismo se divide en dos tipos de escritores: los minimalistas formales y los sociales. Y aunque hay varias características recurrentes en los dos, como el lenguaje claro y coloquial, las tramas sencillas, así como el uso del tiempo presente y la tercera persona. Facknitz se refiere al minimalismo social como "dirty realism" o "K-mart realism", muy diferente a la versión más ilustrada (714).

En ese sentido, Hemingway y Miller, ambos representantes de la generación perdida, pertenecen al minimalismo formal y al minimalismo social respectivamente. La producción literaria del realismo sucio norteamericano presenta tendencias que reflejan una actitud de inconformismo frente a la realidad circundante. Tanto la primera guerra mundial, como la gran crisis económica de los años treinta, la segunda guerra mundial y la guerra de Vietnam provocan actitudes de rebeldía y protesta en diversos niveles de la sociedad norteamericana. Dichas crisis, a su vez, moldean continuamente la actitud del ciudadano promedio frente a la vida, actitud que se hace evidente en la obra de los escritores de estas respectivas épocas. La literatura sucio-realista norteamericana es una suerte de antología que incluye las obsesiones que dominan la obra de autores como Hemingway y Miller, de la generación perdida ${ }^{9}$, Kerouac y Ginsberg, de la generación Beat, y Bukowski y Carver, del realismo sucio, entre muchos otros.

A pesar de que el realismo sucio norteamericano se desarrolla durante las décadas de los setenta y ochenta, la crítica tiende a relacionarlo con la controvertida obra de Henry Miller. Por ejemplo, Carlos Yusti afirma que los textos de Miller eran "una poética

\footnotetext{
${ }^{9}$ Gregory Stephenson sitúa tanto a Hemingway como a Miller en la llamada Lost Generation que surgió entre la primera y la segunda guerras mundiales, sólo que Hemingway, según él, pertenece a una categoría más ilustrada y Miller a un ala más radical, que es la que precisamente influye sobre el surgimiento y el desarrollo de la generación Beat.
} 
perfumada de inconformismo y rebeldía que venía en plan de echar por tierra todo ese puritanismo de aire acondicionado y hot dog [y que] Charles Bukowski venía detrás, lo único que sus libros eran torpes, ignorantes e impregnados de whisky barato y cachondeo" (1). En este apartado se tomarán en cuenta textos como Tropic of Cancer (1934) de Henry Miller, Factotum (1975 ) y Women (1978) de Charles Bukowski como puntos de referencia para analizar las nuevas formas de expresión de la narrativa cubana del Periodo Especial. Numerosas son las similitudes en el lenguaje de estos suciorealistas y los textos de Pedro Juan Gutiérrez, Ángel Santiesteban y Jorge Alberto Aguiar.

Para la sociedad cubana, la década de los noventa es tan desconcertante como lo son los momentos históricos que hemos mencionado para la sociedad norteamericana. Por ende, no es mera coincidencia que en la narrativa cubana de entonces se observen características similares a las que se perfilan en los textos de Miller y Bukowski. Tres obras que se tomarán como marco de estudio del realismo sucio cubano son las colecciones de cuentos: Trilogía sucia de La Habana (1998) de Pedro Juan Gutiérrez, Los hijos que nadie quiso (2001) de Ángel Santiesteban, y Adiós a las almas (2002) de Jorge Alberto Aguiar Díaz, también conocido como JAAD. Son textos que surgen de las experiencias vividas por toda una colectividad durante la última década del siglo XX, en especial los años que marcaron el Período Especial. Estas tres colecciones de cuentos, cada una a su manera, contienen muchos de los rasgos que se observan en el realismo sucio norteamericano. Tales características se manifiestan mayormente al nivel del lenguaje, por ejemplo el uso de vulgarismos, jerga y malas palabras. Por otra parte, la ortografía y la sintaxis se apartan de las normas tradicionales con el fin de lograr un efecto de oralidad a través de la imitación del lenguaje hablado. Pero no se trata 
solamente de resaltar la oralidad de un discurso cualquiera, sino que el texto se centra en el discurso de los marginados, las voces que salen de los bajos fondos de la sociedad: los carcelarios, las prostitutas, los vagos, los mendigos, los ladrones, los soldados y los matones.

El carácter agresivo y violento del lenguaje sucio-realista, por así denominarlo, tiene como función principal la transgresión, la protesta contra el entorno socioeconómico y contra la degradación generalizada del ser humano en dicho entorno. Algo similar ocurre en las obras representativas del Dirty Realism, ya que éstas se centran en la vida de personajes aplastados por la mediocridad y atrapados en el fracaso, los marginados, los llamados perdedores de la sociedad. Así lo afirma Cintia Santana: "The protagonists of these works were waitresses, cashiers, and construction workers who were divorced, unemployed, over-weight" $(26)^{10}$. Y aunque hay una gran diferencia entre los tipos sociales que menciona Santana y los que aparecen en los cuentos de Gutiérrez, Santiesteban y Aguiar, lo que sí queda claro es que en sus respectivos mundos, tanto los unos como los otros se rebelan contra las pautas y normas establecidas, quedando así al margen de sociedades en las que la rebelión no constituye una opción. Es decir, que si el individuo se niega a regirse por el orden establecido o por las tradiciones impuestas, se declara automáticamente persona non grata para el resto de la sociedad. En los textos de Henry Miller, Raymond Carver y Charles Bukowski, los protagonistas son esos elementos indeseables. Según afirma Bill Mullen, "Carver himself has perhaps best

\footnotetext{
${ }^{10}$ Cuando habla del personaje típico del Dirty Realism, Santana se refiere mayormente a los cuentos de Raymond Carver, en cuyas obras pululan todos aquéllos que no se sustraen a las pautas del ideal del sueño americano. El desempleado, el alcohólico, el divorciado, el obeso y el mediocre obrero, entre otros, son personajes típicos de la obra de Carver, y constituyen elementos que divergen de la imagen idealizada de la perfecta familia norteamericana.
} 
encapsulated that rhetorical indirection toward the function of literature as social protest, [admitting that he writes] about working-class people, and the dark side of Reagan's America" (112). La función del escritor es servir de voz a una protesta social que enmudece en sus personajes, cuya única opción es tratar de sobrevivir dentro de su entorno.

Al igual que los personajes sucio realistas de Carver, sus homólogos cubanos constituyen elementos transgresores, rechazados y menospreciados por la sociedad. Y es precisamente esta dicotomía entre el individuo y la sociedad, entre lo pautado y la transgresión, entre lo ideal y lo real la que aparece en las formas de expresión del realismo sucio, sea cual sea su realización. Alexander Prieto Osorno, al referirse a la obra sucio-realista de autores como Charles Bukowski y John Fante afirma: "Mientras Estados Unidos acumulaba riqueza y poder en todo el mundo, y se enorgullecía y cantaba alabanzas a la 'familia feliz' y al 'hombre de éxito', Bukowski y Fante se dedicaban a mostrar lo peor de aquella sociedad, la enfermedad escondida (y acaso minúscula) de la prosperidad económica" (1). Asimismo, Prieto Osorno opina que tal enfermedad se ha producido también en las sociedades latinoamericanas donde predomina el deterioro social y económico causado, entre otras cosas, por la corrupción política, y que ese deterioro constituye un escenario perfecto para el realismo sucio (1). La afirmación de Carver sobre la América de Reagan, al igual que la de Prieto Osorno sobre las sociedades latinoamericanas presentan una gran paradoja si se comparan con la situación cubana. Mientras que en ambos casos se han producido las condiciones sociales y económicas que promueven la creación literaria sucio-realista, no es de esperarse que en la sociedad revolucionaria cubana donde debe habitar el aspirante a Hombre Nuevo haya cabida para 
este tipo de literatura. Pero a pesar de tal contradicción, en la narrativa cubana ese mundo de deterioro y corrupción desplaza los anteriores textos esterilizados donde el enfoque eran los logros revolucionarios y el ideal del Hombre Nuevo, para dar el papel protagónico al antihéroe, al contrarrevolucionario. Se produce, al parecer, una transmutación del Hombre Nuevo al Hombre Sucio, lo cual representa un cuestionamiento de todo el proceso revolucionario cubano.

Por otra parte, en su comparación del realismo sucio español con el norteamericano, Cintia Santana afirma que, aunque el realismo sucio español apunta hacia un sector diferente de la población, sus protagonistas son, sin lugar a dudas, elementos transgresores, ya que son, por lo general, jóvenes insatisfechos, que independientemente de su clase social, buscan liberarse de las pautas sociales que controlan sus entornos. Cuando el Dirty Realism evoluciona en el realismo sucio español, el perfil de los personajes también se transforma: "While the [American] protagonists [. . .] work, drink and listen to country music, the characters of Realismo Sucio are obsessed with violence, sex, hard drugs and rock and roll" (63). Cabe destacar un contraste entre los personajes sucio-realistas norteamericanos, quienes de una forma $\mathrm{u}$ otra pertenecen a la clase trabajadora, y los personajes hispanos que están totalmente al margen de la misma. Pero a pesar de esa gran diferencia, las formas de expresión que se observan en las obras que están bajo el rótulo de realismo sucio son un arma de denuncia contra el entorno social en ambos casos. Al parecer, la violencia del entorno puede expresarse únicamente a través de un lenguaje sucio, descarnado e igualmente violento. Como afirma Prieto Osorno, "El realismo sucio tiene decenas de narradores en América Latina [y] prostitutas, ladrones, alcohólicos, asesinos y drogadictos pululan en esta 
literatura que intenta mostrar una 'nueva cara' de Latinoamérica, el rostro más oculto y visceral, la faz más dramática y atormentadora" (1).

Los textos cubanos que aquí se observan constituyen una suerte de realismo sucio tropical en los que se narran muy frecuentemente escenas de excesiva violencia lingüística, física y sexual. Prevalecen las escenas de acaloradas discusiones donde abundan los insultos y las amenazas, altercados que terminan en golpizas y asesinatos y encuentros sexuales violentos y descarnados que a menudo desembocan en violaciones, e incluso en episodios necrófilos. La función transgresora del lenguaje sucio realista de los autores se observa principalmente a través de la irreverencia lingüística, ya sea de tipo sintáctico, ortográfico o léxico. Además, en estos textos se da un fenómeno en el que, según explica Roland Sodowski, el escritor minimalista (sucio-realista), en su afán por desaparecer del texto, abandona muchas de las técnicas que sirven de guía al escritor posmoderno y que le recuerdan al lector que la historia tiene un escritor que le ha dado forma al texto. Algunas de esas técnicas son el flashback, la retrospección, la introspección, el uso de bastardillas y de una puntuación no convencional. Sodowski cataloga este esfuerzo del autor como una necesidad de lograr el effacement; es decir que él mismo se borra del texto, sin dejar rastro alguno de su presencia mediadora (5). El objetivo del effacement es permitir que el lector entre en contacto directo con el personaje y que logre situarse en su entorno.

Las colecciones de cuentos que ocupan este estudio no son sino compilaciones de historias de individuos que a la vez representan toda una colectividad. Tanto Trilogía sucia de La Habana, como Los hijos que nadie quiso y Adiós a las almas constituyen vívidos retratos de la vida de seres marginados, hundidos en la decadencia. Es una 
literatura que muestra, por primera vez en la narrativa cubana de la revolución, la cara oculta de un cuadro bifronte. En estas historias, contrario a lo que sucede en décadas anteriores, pierde su papel protagónico el Revolucionario, el ciudadano modelo, el individuo sacrificado hasta la muerte por la causa comunista. Ése se esfuma de la escena para dar lugar a los que, hasta el momento, habían tenido el papel antagónico o que simplemente no tenían guión. De hecho, son tan ubicuos los seres marginados en estos textos que hasta dejan de ser ellos los alienados para preponderar sobre el protagonista de antaño. Como comenta Luis Arturo Hernández, Trilogía es una especie de viaje al fondo de la ciudad, un viaje por el proceso de degradación moral de un cubano durante el Período Especial. Es una "evolución o involución, en cualquier caso todo menos una revolución que irá haciendo del 'hombre nuevo' un ser antisocial entregado a la busca y la lucha por la vida" (1). Y ese hombre nuevo degradado es también el personaje central de Los hijos que nadie quiso y Adiós a las almas

Trilogía sucia de La Habana es una colección de anécdotas en las que el personaje principal, Pedro Juan, ofrece muy a lo casual (o así lo parece) un amplio panorama de su crudo entorno. Pero Pedro Juan no es un simple observador de esa realidad, sino que forma parte activa de la misma. Aunque en el pasado el personaje ha gozado de cierto prestigio y amplitud económica por su profesión de periodista, su situación ha dado un gran vuelco debido a la crisis económica por la que pasa Cuba en el Período Especial. Es por eso que la vida del protagonista se centra en un miserable e improvisado cuartucho en la azotea de un derruido edificio del barrio de Centro Habana: “Aquí sólo viven negros, viejas desastrosas, un par de putas jóvenes y otras ya destruidas [. . .] y decenas de guantanameros que emigran en oleadas y nadie sabe cómo caben 
veinte en un cuarto" (205). Ahora, desde su miserable existencia de hambriento desempleado, analiza lo absurdo de su vida anterior. El Pedro Juan desempleado, aun dentro de la miseria que le rodea, pero exento de todo compromiso político, se libera de la censura para describir, desde abajo, la realidad de los de abajo. Presenta la voz marginal del profesional venido a menos, de la mulata jinetera, del vago, del mendigo, del suicida, del ladrón, e incluso del que trabaja todo el día para recibir un sueldo miserable, en fin, de todos los derrotados.

Es una amalgama de voces que se escuchan a través de una: la voz narrativa, y esa fusión se hace evidente en las formas de expresión de la Trilogía. El lenguaje de Pedro Juan autor, narrador y protagonista de estos cuentos, es tan crudo y soez como sórdido es su ambiente. Así describe el baño común del solar donde vive: "Y en el baño la mierda llega al techo. En ese baño cagan, mean y se bañan todos los días no menos de doscientas personas. Siempre hay cola. Aunque te estés cagando tienes que hacerla" (80). Cabe destacar que el personaje de Pedro Juan afirma su admiración por escritores norteamericanos tan irreverentes como él. Por ejemplo, al narrar uno de sus días típicos, cuenta: "Desayuné una taza de té, cagué, leí unos poemas homosexuales de Allen Ginsberg, y me asombré con 'Sphincter' y con 'Personal ad'. I hope my good old asshole holds out" (9) ${ }^{11}$. Tal irreverencia responde al entorno extremo que en sus historias se

\footnotetext{
${ }^{11}$ Allen Ginsberg, renombrado poeta norteamericano y miembro de la generación Beat fue enjuiciado en el año 1957 a causa del lenguaje presuntamente obsceno de su obra Howl. La fiscalía pretendía censurar la obra de Ginsberg y prohibir su distribución en los Estados Unidos y su lectura y discusión en las universidades norteamericanas. Ginsberg ganó el caso el trece de abril de ese año, y se autorizó la venta y distribución de su obra original, en lugar de la revisada, cosa que hasta entonces se había prohibido. Las revisiones que se habían hecho en Howl consistían estrictamente en eliminar del texto las obscenidades. Según Jonah Raskin, las palabras "fuck" y "ass" por ejemplo, fueron sustituidas por puntos suspensivos: "Who let themselves be ... in the . . by saintly motor / cyclist, and screamed with joy".
} 
desarrollan. Es como si sólo un lenguaje crudo e irreverente pudiese comunicar situaciones tan grotescas y absurdas como las que dominan estos textos ${ }^{12}$.

Adiós a las almas es una breve colección de cuentos autobiográficos donde el protagonista, JAAD (Jorge Alberto Aguiar Díaz) narra sus peripecias para subsistir tanto en La Habana como en Madrid. La ciudad carece de importancia porque la clave está en el comportamiento y la actitud del protagonista, que ronda las más bajas esferas de la sociedad, rodeado de prostitutas, mafiosos, drogadictos, ninfómanas, homicidas y suicidas. JAAD, al igual que Pedro Juan y el Henry Chinasky de Bukowski, es parte del entorno que describe, y dentro de éste subsiste a duras penas. JAAD es un personaje frustrado porque quiere ser escritor, pero está atrapado en un mundo delictivo y antisocial al que nunca llega la tan deseada inspiración poética. De todas las carencias que se presentan en el entorno de JAAD, la falta de inspiración es la más dolorosa, porque la creación literaria es la única salida viable para este hombre postmoderno que necesita crear para trascender. Como explica Brewer, algo parecido sucede con Bukowski, ya que el eje central de su obra es la idea de que la creación literaria es "a regenerative necessity, a compulsive antidote to the tedium and dissappointment of daily life and fellow humans"(5).

${ }^{12}$ El lenguaje de Charles Bukowski muestra características semejantes al de Gutiérrez, sobre todo cuando describe las situaciones más bajas y denigrantes del individuo. En Factotum, for ejemplo, el realismo sucio se hace evidente en el personaje de Henry Chinaski, una especie de renegado, un Pedro Juan norteamericano. La similitud entre los dos personajes radica en que ambos son hombres fracasados y hastiados de la vida, hombres que sólo con el sexo y el alcohol logran evadir su aplastante frustración. Su actitud se observa en el lenguaje que ambos utilizan en narraciones como la siguiente: "I had the running shits [...]. Then I got up and wiped, looked. What a mess, I thought, what a lovely powerful stink. I hadn't wiped myself very well. When I got up to look for a beer there was a brown stain" (118). La obra de Bukowski, según Gay Brewer, es una especie de introducción a toda la obra sucio-realista que vino después, en particular a la obra de Raymond Carver. Sin embargo, la insistencia de Bukowski en escribir acerca de la clase baja, utilizando un lenguaje escatológico y un humor despreocupado, mucho más agresivo que el de Carver, lo sitúan en una categoría estilística e ideológica radicalmente diferente a la de sus seguidores $(6)$. 
La falta de inspiración hace que la vida de JAAD carezca de sentido, pero otro factor que contribuye al carácter absurdo de su vida es que también carece de identidad propia. Aunque se mueve dentro de ese mundo delictivo, se comporta como un extranjero, incluso en su propio país. Actúa como si no lograra encajar ni en el mundo de "los buenos" ni en el de "los malos", o quizás como si todavía existiese en él un minúsculo vestigio de nobleza que lo hace levemente superior a quienes lo rodean: "Hablando con él aprendí que el camino de un tipo duro comienza con las putas [. . . ] después el hurto, el atraco, el robo con fuerza, la marihuana, el haschich, el tráfico de inmigrantes y la pornografía. La consagración llegaba con la droga fuerte" (12). Como bien lo expresa el título de esta colección de cuentos autobiográficos, éstas son historias que reflejan la degradación total del ser humano, seres que han perdido sus almas, convirtiéndose en cuerpos que soportan sus paupérrimas existencias como zombis. Pero de todos los afligidos por esta degradación, sólo JAAD se percata de que ha tocado fondo, y que fallidos serán sus intentos por salir nuevamente a la superficie.

Es una suerte de filosofía del desencanto del ser humano que también se aprecia en el Chinaski de Women, cuando, luego de abandonar el último de una cadena de empleos miserables y absurdos, el protagonista concluye: "I had imagined myself special because I had come out of the factories at the age of 50 and become a poet. Hot shit. So I pissed on everybody just like those bosses and managers had pissed on me when $I$ was helpless. It came to the same thing. I was a drunken spoiled rotten fucker with a very minor minor fame" (Bukowski 240). Es evidente que una imagen como la que Chinaski tiene de sí mismo, pues se presenta como la "viva" imagen del fracaso y del desencanto, no puede expresarse de otra manera que no sea con el lenguaje brutal y amargo que aquí 
utiliza Bukowski. Sólo las malas palabras y los insultos pueden reflejar el verdadero sentir de este personaje que sabe que se hunde cada vez más en la frustración que produce la mediocridad.

Los hijos que nadie quiso es una compilación de cuentos en la que Ángel Santiesteban presenta una imagen casi quirúrgica de las vidas de grupos específicos; entes que, por una u otra causa, se han incorporado a las filas de los indeseables, de los rechazados, de los olvidados. Los sujetos a los que Santiesteban dedica sus cuentos son los presidiarios, prestando especial atención a la vida y función de los homosexuales dentro del entorno penitenciario; las jineteras y jineteros con sus continuas peripecias para embaucar a los inocentes turistas; los olvidados soldados cubanos cuyas vidas se esfumaron en los distantes campos de batalla africanos durante las conocidas campañas internacionalistas cubanas; los balseros, atrapados entre deseo de escapar y el miedo a la muerte que les espera en las aguas del estrecho de la Florida; y por último los lobos, los matarifes que arriesgan sus vidas en el robo y la ilícita matanza de reses atropelladas por un tren, para traer a su familia el tan ansiado trozo de carne, actividad que durante el Período Especial se convierte en un oficio para el que se requiere tanto coraje como destreza. La voz narrativa de Los hijos que nadie quiso tiene, por lo general, matices autobiográficos, si bien el narrador logra distanciarse lo suficiente como para que muchas veces esa voz adquiera un carácter de narrador omnisciente. Se produce en los textos de Santiesteban una suerte de détachement intérieur, pero no el effacement del escritor al que se refiere Sodowski.

El distanciamiento que logra la voz narrativa hace que los cuentos de Santiesteban tengan un efecto tan chocante como los de Gutiérrez y Aguiar Díaz porque, aunque 
parece desasirse de la pasión y apartarse de la excesiva espontaneidad del lenguaje hablado que caracteriza a éstos, Santiesteban demuestra los mismos niveles de irreverencia: "Pasa un rato y se escuchan sus gritos de la oficina de Orden Interior rompiendo la quietud de la noche en el penal, grita pinga, cojones, se caga en sus madres, se oyen unos ruidos secos [. . . ] lo amordazan, lo arrastran por el patio, lo llevan para la galera y lo tiran en su cama" (17). Nótese cómo este narrador es capaz de mezclar en un corto fragmento los gritos y las palabras provocadoras con elementos tan contrastantes como "la quietud de la noche". Pero esa capacidad de Santiesteban para producir un discurso que fluctúa entre registros tan contrastantes es lo que atrae al lector que en vano se empeña en predecir los altibajos discursivos que se producirán en el texto.

En estos cuentos se aprecia un claro objetivo de retratar sin adulteraciones la realidad, por cruel y nauseabunda que sea. De hecho, estos escritores parecen regodearse en la vida de las bajas esferas sociales y humanas, tal y como lo hacen en sus obras Miller y Bukowski. Es lo que Robert Rebein, estudioso del realismo sucio norteamericano afirma cuando dice: "Dirty Realism [. . . ] refers to an effect in both subject matter and technique that is somewhere between the hard-boiled and the darkly comic. It refers to the impulse in writers to explore dark truths and descend [.. .] into the darkest holes of society and what used to be called "the soul of Man"” (43). El argumento de Rebein cobra sentido en los textos de Henry Miller, quien se sumerge en las profundidades del decadente mundo parisino para luego traerlo a la superficie y lanzarlo a la cara del lector burgués, aquél que sólo desea ver la fachada glamorosa de la gran capital. Pero ese lector también se verá intrigado por esa otra cara oscura de la ciudad que Miller descubre. Como afirma Blaise Cendrars, Miller es "an American who dives in the lower depths, 
who latches on to harlots and drunks in all kinds of neighbourhoods; a stranger who seeks and flees the nightwalkers of Montparnasse and Montmartre, who listens to their stories and tells them more often dizzy with hunger" (23-24). Y para representar tales profundidades, el lenguaje que se emplea es uno que, por su naturaleza descarnada y provocadora, sirve de imán para atraer al lector, aunque a simple vista parezca que el efecto que produce el lenguaje de Miller sea el rechazo.

Una de las características que se les han adjudicado a los textos del Dirty Realism norteamericano, y que volvemos a encontrar en los textos sucio-realistas cubanos, es el uso del lenguaje popular. Ese lenguaje se presenta no sólo a través del léxico, como las malas palabras, sino además en la sintaxis fragmentada y en la ortografía que imita la pronunciación relajada del dialecto habanero. El objetivo de este tipo de lenguaje es, al parecer, lograr el nivel de oralidad necesario para crear un efecto de verosimilitud, ya que las situaciones que se presentan en estas historias son tan extremas que casi parecen ser producto de la prolífica imaginación de los autores. Por ende, el lenguaje popular, el argot, las frases fragmentadas y los errores ortográficos que imitan la fonética real en el dialecto del bajo mundo otorgan a las situaciones narradas un sello de autenticidad. Estos aspectos aparecen, por su parte, en un resumen que presenta Julian Smith de las características del realismo sucio de Bukowski, entre las que se encuentran: "Disorderly syxtax, first person narration, street language, a no-bullshit approach, misspellings, slang and swearing" (57). Al mismo tiempo, este tipo de lenguaje provoca que el lector traspase la barrera de la forma, para adentrarse de lleno en el contenido. Esto refleja la idea de Tomas Dobozy de que el realismo sucio norteamericano no es más que el resultado de la imperiosa necesidad de un programa contracultural, y que la hipocresía estética de 
Charles Bukowski a la que se refiere la crítica no es sino un reflejo de la hipocresía del propio capitalismo que éste critica en sus obras (44).

La re-creación del lenguaje hablado desempeña un papel clave en la representación de la realidad. El hecho de que la voz narrativa utilice la jerga de la calle, en especial las malas palabras, hace que esta voz se sitúe al nivel del entorno, y no por encima de éste; por consiguiente, la narración se convierte en una fuente fidedigna de información ya que la voz narrativa, al colocarse dentro de la escena, abandona el papel de observador para convertirse en partícipe. Por medio de la oralidad, el lector percibe el verdadero sentir del personaje, sin la interpretación adicional de la voz narrativa, es decir, sin intermediarios. Por ejemplo, al encontrarse con las siguientes frases, el lector percibe claramente la frustración del personaje René, amigo de Pedro Juan, cuando habla de su hijo, un traficante de mariguana que ha abandonado el país en una balsa y de quien no ha recibido noticia: "No sé nada. Al carajo, Pedro Juan. Al carajo todo el mundo [ . . .]. ¡A la pinga todo el mundo! Ya me han dado tantas patás por el culo que no quiero saber de nadie!" (18).

Otro aspecto del lenguaje en los cuentos sucio-realistas es la presencia recurrente de insultos y calificativos agresivos y deshumanizantes. Esta característica cumple con la función de captar la violencia y la agresividad que controla la vida y las acciones de los personajes. El uso de insultos pone de manifiesto, entre otras cosas, una intencionalidad subversiva que se proyecta en la interacción entre los personajes. El insulto y la violencia del lenguaje no son sino una estrategia para verbalizar una protesta contra un orden establecido (socio-político o literario) que, expresada abierta y directamente, sí sería castigada por la censura. Un personaje que ilustra este punto de vista es Johnny P., 
personaje principal del cuento “¿Cómo hacen el amor los patos?” de Aguiar. La voz narrativa en este cuento es el personaje de JAAD, un escritor cubano que se encuentra en Madrid con motivo de un congreso literario, del cual ha logrado escabullirse porque éste le parece "falso y ampuloso y los escritores oportunistas y pendejos" (7), para convertirse en un vagabundo que en ocasiones se junta con Johnny P., una especie de alter ego. Johnny P. es un matón también de origen cubano, que se desplaza por la ciudad de Madrid con JAAD. Johnny P. es un personaje cuyo discurso revela una incontrolable ira, y un odio desmedido contra la humanidad en general.

La mujer, en especial la prostituta, es uno de los principales objetos del desprecio de Johnny P. que, al apadrinar a JAAD, expresa clara y violentamente su opinión sobre la figura femenina: "Todo por una puta. Le caí a golpes y le corté la cara. Las mujeres no deberían existir. Solamente la madre de uno [ . . . Las putas dicen que no y lloran, pero les encantan los golpes" (9-10). El lenguaje violento para referirse a la mujer prevalece en los cuentos de Aguiar, en especial, como ya se ha dicho, contra la jinetera, la prostituta. Parece que, de cierto modo, la intención de la voz narrativa es atacar, más que a la prostituta, a la prostitución, al sistema que ha permitido tal degradación social y humana en la mujer. De hecho, una de las escenas más violentas de Adiós a las almas tiene lugar precisamente entre Johnny P. y una prostituta. Es una escena cruda y grotesca en la que el lector sencillamente se convierte en testigo del hecho, como si estuviese parado en un rincón del lavatorio del cafetín observando lo que ocurre, pero maniatado, incapaz de impedir lo que ve. He aquí algunos de los fragmentos de esta escena: "Ana tuvo que quitarse la ropa y Johnny P. me ordenó que la montara [. . .]. Paco tuvo que subirse arriba de Ana y metérsela por detrás [ . . .]. Cada vez que la muchacha trataba de 
decir algo él la callaba a patadas. La arrastró hasta el inodoro y le hundió la cabeza" (29$30)$.

Cabe destacar que la voz narrativa, es decir JAAD el narrador testigo, presenta la escena sin pronunciar juicio alguno. Al parecer, JAAD permanece indiferente a las atrocidades que se cometen contra la prostituta. La actitud indiferente del narrador, empero, es sólo una fachada, porque en realidad JAAD teme a las represalias que Johnny P. pueda tomar contra él. Por eso prefiere callar, y se limita a aparentar que está de parte de Johnny P. Con todo esto, está claro que Aguiar-Díaz ha tocado el tema de la represión de una manera clara y sutil a la vez. Es posible que la actitud de JAAD, el miedo disfrazado de indiferencia, sea un reflejo de lo que ocurre en el entorno real del escritor donde el silencio es la forma más eficaz de autocensura.

Los cuentos de Aguiar sí contienen numerosos ataques directos contra los "chulos", hombres que, asumiendo el papel de proxenetas contribuyen día a día a la explotación de la mujer. En otros textos como "Cielo sobre Havana", JAAD presenta la vida en el solar habanero donde habita y describe la relación de una pareja vecina en la que el marido vive de las ganancias de su mujer en la prostitución: "El tipo llegaba de la calle a esa hora y le entraba a golpes. Un mulato ex presidiario que la ponía a putear por un dólar en Monte y Cienfuegos" (52). La violencia se presenta desde ambas perspectivas, cuando es la prostituta quien narra las agresiones de las que ha sido víctima por vivir de la prostitución. En el cuento "Putas en miniatura", Sailín, una chica de apenas quince años, explica el origen de la cicatriz que tiene en el rostro: "Jaime no es ningún chulo. Jaime no nos quita el dinero como el Negro. El Negro sí era un hijo de puta [...] era un singao. Me picó la cara" (43). 
En los cuentos de la colección Los hijos que nadie quiso, de Ángel Santiesteban, se percibe un lenguaje igualmente violento, en especial en relación con la figura del homosexual, específicamente dentro de la cárcel. El presidiario homosexual es doblemente marginado, y aunque Santiesteban lo presenta como víctima de su entorno, deja filtrar en sus textos un sentimiento de desprecio hacia esa figura. Aunque el lenguaje que utiliza Santiesteban no es tan descarnado como el de Aguiar y Gutiérrez, no deja de ser igualmente violento. En esta colección hay dos cuentos dedicados (por así decirlo) a la vida (por así llamarla) del homosexual en la cárcel. Los títulos de estos cuentos son "La Puerca" y "La Perra". Simplemente a través de estos títulos, el lector percibe una violencia implacable contra la figura del homosexual. Estos personajes carecen de identidad, ya que no hay un momento en la historia en que se les dé nombre propio. La violencia de los apelativos que se les adjudica radica no precisamente en que se les den cualidades femeninas, lo cual ya parece representar un descenso en el rango humano, sino en el hecho que se les otorga nombres de animales. Tanto la Puerca como la Perra, en sus respectivos entornos, han sido totalmente deshumanizados, convirtiéndose en simples objetos sexuales a merced de los presos poderosos, los que están por encima de la ley de la prisión, los que de hecho dictan sus propias leyes dentro de la cárcel.

La Perra es castigada por ayudar a un preso incomunicado. Sin embargo, a pesar del intento deshumanizador que se advierte en el apelativo, este personaje presenta un carácter innegablemente humano y sensible. Cabe anotar que la voz narrativa, si bien testigo de las experiencias de la Perra, casi se borra por completo de la narración para así presentar los sentimientos, miedos y frustraciones del personaje sin intrusiones. Es por eso que la escena de la violación de la Perra es tan cruda, precisamente para lograr el 
efecto deseado del autor de presentarla como una víctima, para concederle acaso unas escasas migajas de la humanidad que se le ha arrebatado en la cárcel:

El Moro lleva en la mano un tubo de goma negro propiedad de los sargentos [. . .]. La empuja y con fuerza brutal la alza, la inclina obligándolo a apoyar la cabeza contra la pared, [. . .] y la penetra violentamente [ . . . . La Perra se muerde la mano para no soltar un quejido de dolor [. . .]. Apenas termina, el Moro se sube el zipper y con ira y una mueca de asco la golpea con el bastón en la espalda y la Perra cae [. . .]. Se retuerce en el piso. (52-53)

El lenguaje obsceno no siempre responde a una intención de re-crear una realidad cruda ni grotesca, sino que a veces se trata de un simple deseo de transgredir, de pronunciar lo prohibido, y que a la vez coincide con el deseo de los textos tremendistas de épater le bourgeois que se menciona en el apartado anterior ${ }^{13}$. Esa necesidad la señala Ignacio Echevarría en un estudio sobre la novela El índice de Dios (1993) de Roger Wolfe: "La voluntad de transgresión se libera mediante expedientes tan infantiles como el gamberrismo verbal (y culo y coño y polla y polla y polla)" (cit. en Santana 112). Ese tipo de actitud provocadora se observa de manera recurrente en la obra de Henry Miller. Quien recibe su misión como escritor de esta manera: "To reveal myself as openly, nakedly and unashamedly as possible [...]. Examining my own life, describing it in detail, exposing it ruthlessly, I believe that I am rendering back life, enhanced and

\footnotetext{
${ }^{13}$ Bukowski demuestra una crudeza similar en la descripción de un acto sexual en el que irónicamente la víctima de la casi-violación es el hombre: "Her triangle of cunt hair was almost hidden by the dangling, bouncing stomach [...]. She pushed her tongue into my mouth. It was thick with saliva, I gagged and pushed her off. She gripped my balls mercilessly with both of her hands [. . .]. Giving my balls a tremendous yank while almost biting my pecker in half she forced me to the floor" (36-37).
} 
exhalted to those who read me" (194). Esta afirmación de Miller puede dar cabida a la propuesta de que la intencionalidad de los autores cubanos que aquí nos ocupan sea, además de provocar y transgredir, ofrecerle al lector reprimido la capacidad de liberación y de alivio. Es decir que el texto tiene una especie de propiedad catártica a través de la cual el lector abandona sus prejuicios y miedos, literarios o de cualquier índole, para asumir el texto como lo ve Pedro Juan Gutiérrez: "El arte sólo sirve para algo si es irreverente, atormentado, lleno de pesadillas y desespero. Sólo un arte irritado, indecente, violento, grosero puede mostrarnos la otra cara del mundo, la que nunca vemos o nunca queremos ver para evitarle molestias a nuestra conciencia" (105). Esta filosofía aparece en el cuento "Yo, revolcador de mierda", título que ya, de antemano, revela la intencionalidad provocadora del texto. En el arte, cualquiera que fuere su manifestación, Pedro Juan rechaza la hermosura y pone en tela de juicio la legitimidad de un artista que no sea irreverente, como su antigua mujer, cuyas esculturas siempre le parecieron demasiado bellas para ser legítimas: "Había demasiada paz en sus esculturas para ser buenas" (105).

Los cuentos de Ángel Santiesteban exhiben una similar intencionalidad de transgresión. $\mathrm{Y}$ en muchos casos, esta transgresión no tiene relación ninguna con el erotismo ni el sexo. La crudeza de la imagen en Santiesteban no parte de lenguaje obsceno, sino del desenfado con que describe las escenas más grotescas, creando en el lector un deseo de apartar la vista, pero de continuar leyendo cada página. Esta estrategia narrativa se observa principalmente en el cuento "Lobos en la noche", sobre un par de matarifes que roban carne para alimentar a sus familias. "Lobos en la noche" presenta numerosas situaciones que, siguiendo el estilo de Santiesteban tienen un efecto 
transgresor muy similar al de Gutiérrez y Aguiar, a pesar de las obvias diferencias de estilo y lenguaje. Como ya hemos visto, la incidencia del lenguaje obsceno en Santiesteban es mucho menor que en Gutiérrez y Aguiar, pero el efecto termina siendo el mismo: la repulsión. Santiesteban utiliza técnicas narrativas que se enfocan en crear imágenes donde abunda lo abyecto: sangre, semen, vómito. En ese sentido el efecto transgresor de la obra de Santiesteban es representativo de la teoría de Julia Kristeva sobre el poder de lo abyecto y la abyección. Kristeva sostiene que mostrar imágenes donde predomina lo abyecto, es una práctica transgresiva, ya que va más allá de los límites y prohibiciones impuestos, logrando así perturbar identidad, sistema y orden ${ }^{14}$.

El protagonista, acompañado de su amigo tarado, se lanza de un tren que ha atropellado a una serie de reses que dormían sobre la línea ferroviaria. Las reses ruedan por la hierba incapacitadas para moverse y huir. La descripción de la matanza se realiza de una manera directa y sin tapujos: "Mientras Esteban le amarra la boca para que su mugido no nos delate [. . . ] saco el cuchillo y se lo clavo en una de las patas y un chorro de sangre se estrella contra mi cara y cierro los ojos y la boca, pero sigo el corte" (25). Si bien el enfrentamiento entre hombre y animal es violento y grotesco, más lo es el primitivo y salvaje enfrentamiento entre los matarifes en su lucha por llevarse lo que han venido a buscar: "Es muy difícil adueñarse de una sin que otros la rodeen al mismo tiempo. No quiero que suceda que en la desesperación, la ambición y el odio, los cuchillos se confundan y penetren en mi brazo, cercenen dedos, o amanezca al lado de los restos deshuesados de estas reses con un orificio en la aorta" (25).

\footnotetext{
${ }^{14}$ La teoría de Julia Kristeva sobre lo abyecto y la abyección aparece en su obra Pouvoirs de l'horreur (1980).
} 
En ese cuento los matarifes quedan completamente deshumanizados, ya que se comportan como animales disputándose una presa. Desaparece todo límite entre hombre y bestia, e incluso se invierten los papeles hombre/animal, víctima/victimario. El mensaje que subyace a este cuento es que la peor de las carencias para el ser humano es la pérdida de su humanidad, mensaje que se observa también en "La Perra" y "La Puerca". Santiesteban utiliza formas de expresión irreverentes y transgresoras, que responden a la función de mostrar la cara del mundo que no se quiere ver, a la que se refiere Gutiérrez. Por otra parte, éstas también cumplen con una función de exorcismo parecida a la que menciona Henry Miller a propósito de su obra: "The writing may have seemed monstruos . . . but I became a more human individual because of it. I was getting the poison out of my system, no doubt" (cit. en Parkin 252).

Los diversos microcosmos que emergen a la superficie de los textos de Gutiérrez, Aguiar y Santiesteban responden a las realidades que se viven durante la década de los noventa. Estas realidades constituyen fuerzas motrices para el desarrollo de una literatura donde abundan formas de expresión impensables en décadas anteriores. Y aunque estas realidades difieren innegablemente de las que afloran en la obra de representantes del realismo sucio norteamericano, el factor humano de las mismas es lo que constituye el verdadero nexo con su versión tropical. Como afirma Gay Brewer, la novela Factotum de Bukowski, al igual que Ask the Dust (1939) de John Fante, otro de los precursores del Dirty Realism, "are tied by the poverty of their protagonists and by a nearly ahistorical attention to the unique individual crisis of starvation (whether physical or spiritual)" (18). Los personajes marginados que inundan los cuentos de Gutiérrez, Aguiar y Santiesteban, es decir las prostitutas, los homosexuales, los criminales y los mendigos entre otros, son 
similares a los "protagonistas" de las obras del realismo sucio norteamericano por su apabullante mediocridad.

Tomas Dobozy ha notado que el sello de Dirty Realism que las obras de Carver, entre otros, recibieron de Bill Buford ha dejado de ser puramente norteamericano para pasar a formar parte de diversas culturas y grupos sociales y étnicos, ya sean hispanos, canadienses, mujeres, clases bajas o medias (11). Dobozy agrega que la ausencia de una característica unificadora entre los diferentes textos sucio-realistas, sólo sirve para demostrar que si existiese una característica recurrente en las obras del realismo sucio cualquiera que fuere, sería precisamente la disparidad (11). Sin embargo, además de esa disparidad, existe otra fuerza unificadora entre todas las realizaciones del realismo sucio, y es la necesidad de crear un discurso contracultural que provoque en el lector una mezcla de molestia, interés, incertidumbre y cuestionamiento. Gutiérrez, Aguiar y Santiesteban producen una amalgama de estos efectos en sus textos, tal y como lo hacen Miller, Ginsberg y Bukowski y todos los que, de una forma u otra, han sido señalados por la crítica como precursores o representantes del realismo sucio norteamericano.

A pesar de las similitudes que se hacen evidentes entre el realismo sucio norteamericano y la variante cubana, existe un elemento contrastante entre ambas tendencias. Este elemento tiene que ver con el mensaje que subyace a los textos de los autores cubanos que se han estudiado en este capítulo: un cuestionamiento implícito de todo un proceso revolucionario que prometía eliminar las lacras del capitalismo y crear una sociedad donde no hubiese seres marginados ni explotados, donde todo hombre sería un Hombre Nuevo. Los textos de Gutiérrez, Aguiar y Santiesteban echan por tierra ese ideal del Buen Revolucionario, para dar cabida al enajenado y al decadente. La 
importancia que cobra el personaje "contrarrevolucionario" sobre el "revolucionario" en la obra de estos autores sugiere una gran falla en el proceso revolucionario cubano. Y es precisamente esa falla, al igual que el desencanto que provoca la caída del ideal del Hombre Nuevo, lo que induce a la creación de personajes como Johnny P., Pedro Juan, los matarifes, la Perra, JAAD, las prostitutas, los proxenetas, los borrachos y los mendigos. Ellos son "contrarrevolucionarios", no porque se expresen ni actúen abiertamente en contra del sistema político establecido, sino debido a su incapacidad de vivir por la revolución y de luchar estoicamente por materializar el ideal revolucionario. Han abandonado el molde del Hombre Nuevo, situándose al margen de una causa que no consideran suya. Por otra parte, estos seres marginados sufren una metamorfosis pues dejan de ser la excepción, para convertirse en la regla, no sólo en la literatura, sino en el entorno social en que existen.

Los elementos discursivos que caracterizan el tremendismo y el realismo sucio constituyen la reacción del escritor a la realidad social, económica y política que le rodea. En ese sentido el escritor expresa su protesta personal contra el entorno, actuando a la vez como vocero de sus personajes. A través de los elementos, tremendistas y sucio-realistas tan abundantes en la obra de Pedro Juan Gutiérrez, Jorge Alberto Aguiar y Ángel Santiesteban, se presenta una realidad hasta el momento desconocida para muchos lectores. O sea, la realidad que ha provocado una total degradación del ser humano, en lugar de convertirlo en Hombre Nuevo. Existe sin embargo un elemento contraste entre el tremendismo visto en La familia de Pascual Duarte y El Rey de La Habana y el realismo sucio que se observa en las colecciones de cuentos, pues los personajes sucio-realistas de los cuentos, como JAAD, Pedro Juan, el Matarife e incluso La Perra, han caído en una 
situación de marginalidad y decadencia luego de haber gozado de mejores condiciones de vida. Por otra parte, las novelas tremendistas contienen un planteamiento que corresponde con un claro determinismo social. Es decir, que tanto Pascual como Rey están destinados a la violencia y a la muerte producto del entorno en que han nacido y crecido, y es justamente esa circunstancia la que dicta la tragedia de su existencia. Ése no es el caso de los personajes sucio-realistas, ya que en un momento determinado, muchos de ellos fueron miembros activos y productivos de la sociedad, candidatos a Hombres Nuevos, la arcilla moldeable de la que tanto se ha hablado. Pero en lugar de alcanzar ese ideal, se degeneran justamente a causa de un proyecto político que se les ha impuesto. De modo que los elementos discursivos vistos en el tremendismo y en el realismo sucio son la voz de una fuerte crítica a ese proyecto político. Con todo esto, cabe afirmar que los textos en cuestión cumplen con su objetivo de presentar la degradación humana que se produce como consecuencia de la decadencia social, económica y cultural por la que atraviesa la isla durante el Período Especial producto de la crisis del proyecto revolucionario cubano. 


\section{Capítulo III}

La temática en la narrativa cubana del Período Especial

Hambre, exilio y nostalgia: Hacia una conceptuación de la carencia

La narrativa cubana del Periodo Especial posee características que van más allá del nivel discursivo, para abarcar también el aspecto temático. Las condiciones socioeconómicas y políticas discutidas hasta el momento, que provocan los cambios en la producción literaria de la última década del siglo XX, no sólo afectan las formas de expresión, sino que provocan marcados cambios a nivel de la temática en los textos de este período. En las lecturas de algunos de estos textos se perfilan tres temas fundamentales: el hambre, el exilio y la nostalgia. Este capítulo analizará cómo se presentan esos temas en los textos escogidos y, sobre todo, qué relación existe entre ellos en cuanto a su función metafórica. El tema del hambre se analizará en todas sus dimensiones a través de la novela El hombre, la hembra y el hambre (1998) de Daína Chaviano. Además, los temas del exilio y la nostalgia se estudiarán a través de los textos Café nostalgia (1997) de Zoé Valdés y Los palacios distantes (2002) de Abilio Estévez. Este estudio tiene como objetivo demostrar que los temas del hambre, el exilio y la nostalgia son metáforas que facilitan la conceptuación de una problemática humana universal y a la vez específica de este momento de la historia cubana: la carencia.

\section{El hambre: Ausencia y búsqueda en El hombre, la hembra y el hambre}

El hombre, la hembra y el hambre de Daína Chaviano ha sido catalogada por la crítica como una novela sobre la Cuba del Período Especial y como una protesta directa y feroz contra las condiciones de vida que imperan en ese momento histórico de la isla. Por ejemplo, Antonio Enrique nota que en esta novela "la denuncia de las calamidades 
que puede infligir un solo hombre a millones de personas es firme, pero [ . . ] tolerante con los disparates del autócrata" (1-2). Sin embargo, si bien es cierto que el texto presenta la realidad política y socio-económica del momento, y que lejos de resaltar los logros de la revolución cubana se centra en sus errores, El hombre, la hembra y el hambre es mucho más que el simple reflejo de un entorno dado. La realidad cubana del Período Especial es sólo un punto de partida o un marco dentro del cual se desarrolla una problemática compleja y multidimensional que ha pasado inadvertida para los estudiosos de este texto. Es la historia del ser humano, un individuo cualquiera (el hombre o la hembra o ambos) acosado por la carencia (el hambre), un ser humano que vive en constante espera y búsqueda de algo y de todo. Por eso, el personaje principal de esta novela es El Hambre. El Hombre y la Hembra son los hombres y mujeres que viven en ese entorno, personajes circunstanciales a través de los cuales emerge la problemática humana en sus diversas manifestaciones y dimensiones. Ellos forman parte de un elenco cuya actuación gira alrededor del personaje central y en función de la trama de un texto que es novela y mise en scène a la vez.

El Hambre no es un personaje unidimensional ni estático, sino que se desdobla en un sinnúmero de dimensiones. Pronto se establecen claramente en el texto las tres manifestaciones principales del Hambre en el hombre: el hambre física, el hambre espiritual y el hambre afectiva. Según la voz narrativa, el hambre física es la más común, aunque no la más dolorosa. Por su parte, el hambre espiritual es peor, ya que a causa de ella se vive en un permanente estado de abandono porque Dios no existe. La última y la más dolorosa es el hambre afectiva, descrita por la voz narrativa como "un instinto, un ardor del alma donde la búsqueda de una caricia se convierte en una pesquisa frenética e 
indiscriminada" (54). Este apartado explora la función protagónica del Hambre en la novela de Daína Chaviano, así como la importancia de sus diversos desdoblamientos, pues el Hambre es tema y personaje a la vez.

El Hambre, como personaje principal del texto, posee una complejidad casi laberíntica. El Hambre se desdobla en el vacío y el anhelo, en la fatiga y el desaliento, en el miedo y la desconfianza, en el desarraigo y el peregrinaje, aspectos todos de un mal general que es la carencia. Así define la voz narrativa su sentir respecto al Hambre: "Siento un hambre milenaria, de esas que corroen la bilis y el alma [. . .]. No logro imaginarme cómo sería la vida sin este afán por devorar, por apoderarme de cada trocito del mundo y convertirlo en parte mía" (41). Por eso es que ésta es una novela del estar en constante búsqueda del ser, un fallido desplazamiento en busca de la permanencia. El mensaje subyacente del texto es que sólo a través de la permanencia se pueden saciar todas las hambres que condenan al ser humano al estado famélico de cuerpo y alma en que se encuentran sumidos los demás personajes de esta novela. No obstante, el texto nunca llega a plantear ni la más remota posibilidad de arribar a tal estado de permanencia, por lo que El Hambre nunca abandona su papel protagónico, convirtiéndose así en un problema irresuelto.

Partamos pues de la categoría considerada como la más común. El hambre física se presenta, más que nada, mediante una crítica de la grave crisis socio-económica por la que atraviesa Cuba durante el Período Especial. Se manifiesta en numerosos casos como la escasez de alimento y el racionamiento, asunto que llega a convertirse en una suerte de leitmotif a lo largo del texto. O sea, que desde el principio los personajes aparecen agobiados por la diaria preocupación alimenticia. En una ocasión se describe el arribo de 
la cuota de carne, con una simple, pero ensordecedora frase “¡Llegó la carne!”, que provoca un altercado entre las amas de casa del solar (82). La voz narrativa se refiere al suceso como "una situación tensa como aquélla: la llegada de la cuota de la carne, tras una demora de dos semanas" (82). Sin embargo, éste no es un incidente aislado, sino que forma parte del modus vivendi, en un solar donde se escuchan frases como "Mira Claudita, conseguí una docena de huevos. ¿Quieres? A veinte pesos están regalados” o “AAllá abajo está el chino de las verduras!” (81). La abundancia de alimento, que rara vez está presente en el texto, representa en realidad lo contrario; es decir, la satisfacción del individuo, que en contadas ocasiones logra saciar un deseo generalmente reprimido. Esa satisfacción, si es que se logra, se torna en comunión con el prójimo. Así lo demuestra el pasaje en que Rubén invita a Claudia a comer a La Bodeguita del Medio en su primera cita:

Comieron con la pasión del peregrino que agoniza en el desierto y descubre, a punto de morir, un puñado de frutas dejado allí por la mano de Dios; comieron con el desespero de quien padece un hambre tan antigua que ya forma parte de su memoria genética. Y mientras saciaban aquel apetito secular experimentaron una rara comunión, como si el ritual de comer - tan escaso que su celebración cobraba visos de magiaanunciara vínculos que trascenderían el presente. (29)

Los personajes de esta novela están severamente marcados por el sistema de racionamiento alimenticio, sobre todo porque las raciones estipuladas para el consumo de un mes sólo alcanzan para dos semanas, y además porque son muy pocos los productos que llegan a los comercios para ser vendidos a la población, aunque estén incluidos en el 
sistema de abastecimiento. Nubia, la amiga de Claudia, y uno de los personajes circunstanciales a los que se ha hecho referencia anteriormente, narra un sueño recurrente en el que viviendo fuera de Cuba, llega a un mercado donde hay de todo y muy barato. $\mathrm{Al}$ llegar a la caja registradora, el tendero le exige que muestre su tarjeta de racionamiento, pero ella no la tiene, y lo peor es que sospecha que la ha dejado en Cuba adonde no puede regresar a buscarla. Así queda condenada a vivir en un país de abundancia sin poder comprar nada porque, aunque en el sueño tiene suficiente dinero, sin la tarjeta no puede adquirir sus alimentos. Es evidente que la falta de alimentos y el vivir sujeto al sistema de racionamiento ha creado un trauma en este personaje. Una frustración como la que experimenta Nubia trasciende el texto de la Chaviano para convertirse en un tema recurrente de la narrativa de esta época'.

La carencia de alimento es un factor que echa por tierra hasta el propio sistema de racionamiento, pues a falta de éstos, no hay qué distribuir entre la población. Claudia, por ejemplo, decide almorzar o "entretener el estómago" con un huevo porque "sólo quedaban cinco de la docena que le compró a Serafina, y nunca se sabía cuándo volverían a aparecer" (83). La escasez alimenticia hace que La Habana, lugar de los hechos, sea el trasfondo del constante desplazamiento de gente que busca el alimento, que hace colas por horas, que marca el turno en la cola desde la noche anterior, gente que va y viene con las bolsas vacías. La situación de las constantes colas para conseguir cualquier artículo alimenticio se presenta muy claramente en el siguiente pasaje: "La tienda abría cada

\footnotetext{
${ }^{1}$ Recuérdese, por ejemplo, el cuento "Lobos en la noche" de Ángel Santiesteban, citado en el capítulo anterior. Cuando el matarife llega a casa, su madre y su mujer comienzan a cocinar la carne y comen durante toda la noche, antes de que se dañe el tan preciado alimento. La angustia por conseguir el escurridizo sustento reaparece en otros textos de esta época como en Informe contra mí mismo (1996) de Eliseo Alberto, en el que una amiga que todavía reside en Cuba le escribe: "Estoy cansada del 'no hay', del 'se acabó', del 'no te toca'" (168).
} 
mediodía, pero las colas empezaban desde la seis de la mañana [. . .]. Se establecieron turnos familiares [. . .]. No era raro que muchas personas se desmayaran a mitad de cola, debido al hambre, la sed, o a las largas horas de espera bajo el sol furioso" (99). Además de las colas y la espera, está presente el peregrinaje circular en busca del diario sustento. De hecho, en la novela se narra la conocida anécdota de la anciana que viene caminando con su bolsa vacía y ya se le ha olvidado si va o viene de la bodega. Se trata de una búsqueda permanente e infructuosa, pero por instinto de supervivencia la gente continúa buscando y esperando, desplazándose por la ciudad.

Si el hambre física es una de las metáforas que ayudan a conceptuar la carencia, sus repercusiones en el individuo van más allá del plano fisiológico, ya que actúa también en detrimento de sus valores morales y éticos. El hambre física tiene como consecuencias directas el robo y la estafa. Con el hambre desaparecen las normas de cortesía; por eso los gritos, los insultos y los ataques físicos. Desaparece también la consideración por el prójimo, ya que predomina la ley del más fuerte, o en este caso, del más astuto. Un caos económico como el que aquí se describe hace que los astutos e inescrupulosos se aprovechen de los más débiles y de los ingenuos. Tal es el caso de la anécdota que cuenta Nubia sobre el hombre que vendía pan con bisté muy cerca de una cola de hambrientos. La gente no le da importancia a la extraña textura de la carne, y continúa comprando el bocadillo, pero al poco tiempo se descubre que dentro de los panes no había carne, sino pedazos de frazada de piso (99). La ley del más astuto se ilustra también mediante el personaje de Gilberto quien, a pesar de ser economista, se tranza por la ocupación de ayudante de carnicero. El propio Gilberto admite mojar el papel en el que envuelve la carne para que pese más, "cumpliendo" así con las cuotas de racionamiento establecidas, 
mientras él y su jefe se apropian del remanente, vendiéndolo luego en bolsa negra. Gilberto admite este hecho sin remordimientos ni vergüenza, mostrándose incluso orgulloso de su astucia y de la ventaja económica y social que su fraudulento oficio le proporciona:

En este país, ser carnicero es mejor que ser médico. Todo el mundo te respeta, te trata bien, se ofrece para resolverte cualquier problema, desde soldarte una tubería rota hasta conseguirte un turno para comer en La Torre. Saben que eres un tipo poderoso que tiene en sus manos el reparto de la carne, el oro de los pobres [. . .]. Te lo dice uno que tiene las llaves del cielo. A ti, como socio, te puedo resolver cualquier pedacito de carne que te haga falta. Y de los inspectores ni te preocupes. Me conozco todos los trucos para sacar la mercancía, aunque venga contada y más que contada. (86)

Claudia es otro personaje que se incorpora a las filas del fraude y la corrupción, y en ellas permanece hasta el final de la novela. A insistencia de una amiga jinetera, y al verse sin empleo fijo y con un hijo al que no puede mantener con lo que gana haciendo algunas traducciones, Claudia termina por unirse a tantas otras mujeres que han descubierto en sus cuerpos la vía más factible para ganar el codiciado dólar. Curiosamente, cuando abandona la prostitución porque ya no soporta vivir presa de sus conflictos morales, es sólo para dedicarse al robo. Cabe destacar que aparentemente el hecho de que Claudia deje de prostituirse para tomar un oscuro empleo en una pizzería se presenta como un cambio positivo en el personaje, ya que ha dejado de vender su cuerpo. Sin embargo, visto de cerca y analizado a profundidad, tal cambio no es más que un 
simple engaño que plantea un serio cuestionamiento ético. En su nuevo empleo en la pizzería, todos roban, y Claudia "no tardó en enterarse que allí todos robaban al por mayor. Por eso las pizzas no tenían suficiente salsa de tomate, ni los espaguetis suficiente queso, ni las lasañas suficiente relleno". Como resultado, Claudia "se sum[a] al proceso de contrabandear con la harina, el queso, los tomates" (300).

La filosofía de los contrabandistas, que son casi todos los personajes de la novela, es que como el único dueño de todo es el Estado, el robo no perjudica a nadie en particular, y que el Estado, dueño absoluto de la riqueza del país, no echará de menos un poco de queso o de harina. Claudia cree haber encontrado "la gallina de los huevos de oro" cuando comienza a vender queso por dólares (300). Al parecer, en este texto hay una escala de valores en la que la prostitución se presenta como la degradación máxima, pero el robo y el contrabando no lo son tanto. Es obvio que el personaje de Claudia aparenta sufrir una transmutación al abandonar su oficio de jinetera pues se siente feliz y liberada al no tener que vender su cuerpo, pero en realidad su satisfacción radica en el hecho de que sin practicar la prostitución, logra mantener el nivel de vida al que ya se ha habituado. Su nuevo empleo le permite lucrar por medio del robo, al parecer una práctica menos vergonzosa que la prostitución.

Otra consecuencia del hambre física que se presenta en el texto es el concepto del "invento", que difiere del fraude (como el fraudulento pan con bisté de frazada) en que es para consumo propio; es decir, que en lugar de engañar a un desconocido con fines de lucro, se engaña a la familia o a uno mismo. El invento alimenticio se presenta como una especie de reciclaje a través del cual el ama de casa, dando muestras de su gran talento culinario e inventiva, logra engañar la vista, el paladar y el estómago de los comensales y 
los suyos propios. En el texto, el invento por excelencia es el picadillo de cáscara de plátano: "Las cáscaras que antes iban para la basura, constituyen ahora un nuevo ingrediente que ha revolucionado la dieta cubana" (102). El texto de la Chaviano está salpicado de ejemplos del invento, porque éste juega un papel fundamental dentro del concepto de la carencia mediante la metáfora del hambre física. El invento no es más que la capacidad (o quizás el instinto) del ser humano de satisfacer una necesidad mediante la negación, pues maquillar las cáscaras de plátano hasta que éstas parezcan carne molida es una manera de negar la carencia de la carne. Es decir, que si se logra la consistencia, el color y el sabor de la carne, pues entonces es carne. Este poder de auto-engaño es un mecanismo de defensa del que se valen los personajes de esta novela para lidiar con su circunstancia.

El racionamiento, las colas, las estafas, el robo, la constante búsqueda del alimento y el invento son elementos intrínsecos de lo que aquí se define como hambre física. Sin embargo, esta hambre física no es un ente aislado, sino que forma parte de una densa madeja con otros tipos de necesidades. La voz narrativa afirma que el hambre física no es tan dolorosa como el hambre espiritual, una que se ha ido transmitiendo a través del tiempo, causando sus mayores estragos en la presente generación. Según el texto, lo más difícil del hambre espiritual es que ataca a una generación que no puede soñar porque las doctrinas impuestas sólo permiten creer en "lo palpable, lo visible, lo medible, lo fotografiable" (54). La falta de vida espiritual provoca en la nueva generación una necesidad, la constante búsqueda de un ser supremo: “Así empezó el hambre devota de mi generación. Necesitábamos de orishas y milagros. Y ahora nos hemos convertido en polífagos. Engullimos como anarquistas. Estamos ansiosos de devorar a Dios" (54). 
Las carencias espirituales se manifiestan en un sinnúmero de personajes y de maneras muy diversas. Encabezando la lista está la ausencia de libertad. Ésta es la carencia de mayor impacto porque tiene implicaciones funestas para la vida espiritual de la gente que vive bajo el sistema totalitario. Desde el principio, cuando se presentan las vidas de los tres personajes secundarios de esta novela (Claudia, Rubén y Gilberto), el lector puede percatarse de que todos ellos han tenido una vida anterior muy distinta a la que ahora viven, y algunos de estos cambios se han producido mayormente a causa de la censura. Rubén, por ejemplo es expulsado de su trabajo como profesor universitario por verse involucrado en la publicación de un artículo que critica al gobierno por un nuevo sistema de empeño en el que la gente entrega todas sus prendas y joyas valiosas a cambio de un ventilador, una hornilla o cualquier otra baratija. La nueva vida de Rubén, como artesano, viviendo de las pocas piezas que logra vender a los turistas, y teniendo que comprar los materiales de contrabando, no es sino un castigo que le ha sido impuesto por atreverse a cuestionar las acciones del gobierno. Claudia, por su parte, también vive una vida totalmente ajena a la que había soñado como licenciada en historia del arte, ya que al descubrir que el gobierno está vendiendo el patrimonio artístico del país se atreve a protestar y a tratar de investigar lo que sucede. Sin mayor preámbulo, la expulsan con una imborrable mancha en su expediente laboral. Cabe destacar que, al igual que en los textos analizados en el capítulo anterior, los personajes de esta novela sufren un descenso social dictado por el entorno político.

Pero así como Claudia y Rubén representan a los que tratan de alzar sus voces contra lo establecido, también están aquellos que asumen la postura del silencio, los que experimentan una carencia que es mucho más dolorosa que la falta de libertad porque 
pierden su razón de ser al sumirse en una constante y progresiva afonía: "Envidio el valor de aquellos que se deciden a gritar, a ser apaleados, a no dejarse vencer. Yo sólo me atrevo a resistir" (123). En ese sentido podemos comparar dos personajes que mantienen diferentes actitudes frente a un mismo sistema de vida. Nubia, amiga incondicional de Claudia, ha perdido lo que casi toda persona necesita para vivir: los ideales. Nubia representa al joven cubano que ha perdido la ilusión de vivir y que se siente, sobre todas las cosas, inútil. Según ella, su intelecto ha sido aniquilado por un régimen totalitario que repele los cerebros pensantes y prefiere un país de sordos-desmemoriados. En una discusión que se produce entre Nubia y Úrsula, la monja, sale a colación el tema de la patria y lo doloroso que sería abandonarla. Nubia tiene una opinión muy diferente a la de Úrsula: "Yo no tengo nada que me ate a este sitio... La patria me la paso por el culo. Me da lo mismo vivir aquí que con los pigmeos de África. Lo único que quiero es que me dejen en paz, poder decidir mi vida y no tenerle que rendir cuentas a nadie" (213). Visto desde una óptica pragmática, esta filosofía de Nubia podría parecer sensata, en especial si se trata de la posibilidad de abandonar la isla en busca de una vida mejor. Sin embargo, una de las ideas principales de esta novela, de la cual Úrsula se hace vocero, es que para buscar el futuro no es necesario alterar la geografía del personaje, sino regresar al pasado, echar raíces. Siempre hay que saber de dónde se viene, para ver hacia dónde se va, y es por eso que la patética anécdota de la anciana que olvida si va a la bodega o viene de regreso cobra tanta trascendencia en el texto. Ella es el símbolo del individuo que, de tanto peregrinar, ha quedado totalmente desorientado pues no sabe de dónde viene ni adónde va. 
La falta de libertad puede provocar grandes crisis existenciales en el individuo, por lo que no es sorprendente que en este texto se presente la ausencia de Dios como uno de los temas centrales: “Aceptaré cualquier cosa que aparezca porque el hambre de un ángel en desgracia es voraz; pero sospecho que Dios se ha marchado" (298). La ausencia de Dios, aunque difiere un tanto de la noción Nietzscheana de que Dios ha muerto, sí coincide con ésta en que tal ausencia sume al hombre en un abandono total y en el nihilismo ${ }^{2}$. Sin embargo, es curioso que mientras la muerte de Dios constituye un hecho definitivo e irreversible que hace que el hombre abandone su búsqueda del ser supremo, en El hombre, la hembra y el hambre, la ausencia de Dios propone la esperanza de un regreso, por lo cual el espíritu de búsqueda permanece latente en el ser humano. "Sólo ha dejado pequeñas huellas — señales difíciles - que hemos ido recogiendo como las miguitas de Hansel, con la esperanza de que nos conduzcan a la salida del bosque [. . .]. Mi generación comenzó a juntar esos pedacitos de Dios, esos fragmentos de luz regados por el mundo" (298).

A pesar de esas huellas, empero, los personajes de esta novela pertenecen a una generación que ha vivido tanto tiempo sin Dios que no puede reconstruir su fe ni aceptar su regreso en un día. Por eso, aunque se acepte la presencia de Dios, es preciso cuestionar su sentido de justicia. Tal vez la ausencia de Dios sea menos cruel para el ser humano que la desconfianza de éste en la justicia divina. De ahí la importancia de las deidades afrocubanas y de las apariciones de espíritus en la novela, pues más que un Dios supremo que puede ser sumamente injusto, el hombre busca entes protectores. En la narrativa de

\footnotetext{
${ }^{2}$ Según Martin Heidegger, Nietzsche define el nihilismo como el estado donde "los valores supremos han perdido su valor [.. .]. Falta la meta, falta la respuesta al porqué" (10). Esta actitud frente a la vida se hace evidente en la mayoría de los personajes de la novela.
} 
Daína Chaviano, así como en mucha de la narrativa cubana, el mito da trascendencia estética a los deseos, los sufrimientos y las ansiedades humanas, y constituye un regreso a viejas metáforas para comunicar las nuevas inquietudes existenciales (Cuervo-Hewitt 238). En cierto sentido, el hambre espiritual se manifiesta de manera similar al hambre física en cuanto a la constante búsqueda. Así como el hombre no abandona su peregrinaje en busca del alimento, tampoco abandona su búsqueda de un ser poderoso y benevolente, sea cual sea su manifestación.

Claudia, por ejemplo, busca varias salidas para escapar de su asfixiante realidad física y espiritual, y una de ellas es la música de Hildegard von Binge, una simple manera de mitigar el hambre de Dios que la agobia. Los cánticos medievales de la abadesa alemana la llenan de paz ya que la llevan a una introspección profunda. No obstante, Claudia es consciente de que la música no es suficiente para saciar la gran sed de Dios que hay entre los suyos, y que apenas funciona como un método de distanciamiento. Al parecer, el argumento que intenta plantear el texto es que el hombre nuevo sí necesita de Dios, pero no lo encuentra: "Lo busco, lo llamo, le grito desde mi alma, pero Él se oculta en el corazón de las ruinas que levantaron mis antepasados [. . .]. Olofi, Olofi, ¿por qué me has abandonado?" (298). Es evidente que en un régimen que ha impuesto el ateísmo, reemplazando a Dios con la Historia y con su propio sistema de ídolos, como el Che y Camilo, este tipo de búsqueda que plantea Daína Chaviano constituye un acto de subversión, pues refleja el rechazo del proyecto ateísta historicista de la revolución.

La falta de permanencia existencial que agobia a los personajes se hace más evidente a medida que se va manifestando otro personaje, el único que perdura, que permanece, que no se rinde frente a la historia: La Habana. La ciudad deja de ser un 
simple escenario para cobrar vida propia y convertirse en un personaje vital, quizás el más vital de todos. La Habana abandona su papel de espacio urbano estético y estático y adopta las complejidades y contradicciones de sus habitantes. A ella se aferra Claudia en sus regresiones temporales cuando necesita encontrarse a sí misma, cuando cree haber perdido por completo su razón de ser. Claudia siente que La Habana siempre la recibe como una vieja amiga, y que sólo le queda aferrarse a la inmortalidad de su ciudad para salvarse ella misma: “Así había nacido y así había continuado, en medio de sus múltiples reencarnaciones sociales. Porque su ciudad era como un fénix: pese a tanta ceniza, pese a los desastres, siempre terminaba por resurgir" (199). En sus constantes regresiones a La Habana colonial el personaje encuentra una forma de evasión, una reafirmación de que la fortaleza de esta ciudad puede de algún modo transmitírsele. La Habana de antes es una celebración de la vida, de lo bueno y también de lo malo, pero celebración al fin, muy a pesar de los horrores que haya presenciado esta ciudad a lo largo de su historia. Con la ausencia de Dios, el magnetismo de la ciudad ofrece al individuo la posibilidad de echar ancla y de descubrir su razón de ser. La clave de este magnetismo parece estar en el hecho de que la ciudad es el reflejo de sus habitantes porque ha envejecido y se ha deteriorado junto con ellos ${ }^{3}$.

Si bien el texto propone diversos mecanismos de defensa para enfrentar el hambre física y espiritual, luego el hambre afectiva, tercer desdoblamiento, supone obstáculos

\footnotetext{
${ }^{3}$ Los habaneros parecen experimentar lo que describe Edmundo Desnoes en el prólogo a Memorias del subdesarrollo, edición del 2006 cuando dice: "En el 2003 regresé a la ciudad después de 22 años en el exilio; durante mi visita descubrí dos cosas: La Habana es la única ciudad del mundo que ha envejecido conmigo, todas las demás ciudades mitológicas han crecido nuevos órganos, barrios, se han renovado, sufrido cirugía plástica. Recorriendo el Vedado, el barrio de mi infancia y juventud, descubrí arrugas en los edificios, grietas del tiempo, pérdida de balaustradas, cuerpos ruinosos. No me entristeció, me sentí acompañado" (15).
} 
aun mayores. Por eso es que la voz narrativa dice: "Bienaventurados Marx y compañía porque — gracias a ellos- nuestro será el reino de los cielos... Quizás allí logremos saciar el hambre más fuerte de todas, la única que se devora a sí misma: el hambre de amor" (54). La carencia de amor es el resultado directo de la desconfianza de Dios y del prójimo. Así que la búsqueda de afecto se hace más difícil ya que el miedo a la entrega total domina toda relación afectiva. Claudia, en sus relaciones amorosas, primero con Rubén y luego con Gilberto, se comporta de manera muy similar, y con ambos experimenta una desconfianza excesiva. Sin embargo, en lo que a Gilberto se refiere, el temor es justificable ya que ha pasado previamente por la experiencia con Rubén, que ha sido bastante compleja y trascendental. Además, Claudia sabe que Gilberto es un hombre casado, y que la relación entre ellos no pasará de un simple romance. En cierto sentido, el compromiso familiar de su amante la libera de la responsabilidad que representa entregarse a una relación sin condiciones. De hecho, cuando se da cuenta de que a Gilberto no le importa salvar su matrimonio, entonces es ella quien abandona la relación. Claudia no puede permitir que Gilberto renuncie a todo por ella porque entonces ella tendría que entregarse totalmente a él, algo a lo que no está dispuesta.

Y aunque es cierto que las reservas de Claudia hacia Gilberto se justifican por la experiencia vivida con Rubén, su actitud hacia su primer amante es de mayor complejidad, pues la dinámica que se produce entre Claudia y Rubén es representativa de la actitud y el pensar de muchos otros hombres y mujeres de la generación que protagoniza esta historia. Cabe observar que la perspectiva de Claudia responde a la filosofía de que abrir su corazón al otro y dejar al descubierto sus sentimientos, sus miedos y sus debilidades es un peligroso error. Pero esa filosofía no es el resultado de 
ningún traumático amor vivido antes de conocer a Rubén, sino que su desconfianza se desprende de una suerte de paranoia colectiva, a causa de la cual a ambos se les dificulta entablar conversación en su primera cita, ya que ninguno de los dos confía en el otro. No saben cuánto pueden hablar ni qué pueden decir sin ser delatados.

Desde el principio el lector se percata de que en este texto el amor se conceptúa a través de los elementos metafóricos de la guerra. O sea que el objeto de la atracción se percibe como un enemigo cuyo comportamiento hay que estudiar a fin de vencerlo. La entrega afectiva es, por lo tanto, una derrota, rendirse al contrario, quedar vulnerable y a merced del ser amado. Por eso, más que una ilusión, ese sentimiento se convierte en motivo de angustia. En una de sus conversaciones con Muba, el espíritu de la negra esclava que se ha convertido en su ángel de la guarda, Claudia expresa lo siguiente: "Con él me siento protegida, o quizás menos sola... y me apena admitirlo porque creo que Rubén siente por mí lo que yo no siento por él... Es que estoy vacía, Muba. Creo que me han sacado el corazón y las entrañas" (79). El vacío parece ser el simple temor de perder lo que se tiene o lo que se cree tener. Aparentemente éste es el miedo de una generación que ha ido perdiéndolo todo, incluso su libre albedrío, paulatina y drásticamente a la vez. A ellos les ha tocado vivir tiempos de decepciones, desilusiones y pérdidas. Como expresa Claudia cuando le explica a Muba la desventaja de estar vivo en su tiempo y espacio: "A veces pienso que ni siquiera la amistad vale la pena si al final se pierde todo: lo bueno y lo malo, pero sobre todo lo bueno, que es lo que jamás se puede recuperar" (80). Para Claudia, estar vivo es una condena, un sentimiento compartido por Rubén y por Gilberto, sólo que ellos no huyen como ella de esa condena, sino que la asumen con resignación. 
El hambre afectiva es un resultado directo de la incapacidad del individuo para entregarse, pero también para aceptar la entrega del otro. En una situación donde el ser humano vive perennemente preparado para lo peor, no conviene bajar la guardia para escuchar los miedos y debilidades de los demás. La actitud de Claudia hacia Gilberto comprueba este argumento. "Otro en quien pueda confiar. Tal vez... Esos tal veces con los que hemos crecido son la raíz de nuestra incertidumbre. Lo cierto es que nunca nos atrevemos a nada porque las cosas podrían resultar peor de lo que ya están" (91). Es evidente que en su actitud se manifiesta una fuerte tendencia al pesimismo, pues pretende evitar el dolor de la espera y sobre todo el dolor de la pérdida. Pero aunque Claudia crea estar vacía, y por mucho que insista en no poder amar, aún queda en ella la sensibilidad de la que tanto reniega, y que se hace evidente cuando habla de Gilberto: "Desconfío de mí cuando un hombre me inspira lástima. Es algo que no quiero sentir, porque detrás de la lástima se esconde siempre un poco de ternura; y no me gusta sentirla, me espanta" (43). Lo que parece un tanto contradictorio es que con Rubén, Claudia afirma no tener capacidad para amar; mientras que con Gilberto, es consciente de su capacidad para sentir, pero le teme a esos sentimientos. Tal vez no sea una contradicción, sino más bien el resultado de un proceso de crecimiento personal. Quizá parezca paradójico hablar de una evolución en este personaje, pero lo cierto es que reconocer y aceptar los sentimientos demuestra una madurez que no se tiene si se trata de negarlos, como hace Claudia con Rubén. En todo caso, Claudia huye de ambas relaciones porque éstas representan un grave peligro para ella: el peligro de dar y recibir afecto sin reservas. 
Claudia tiene una visión sartreana del amor, pues considera este sentimiento "un masoquismo [. . .] una condena [. . .] una trampa" $(151)^{4}$.

Rubén y Gilberto representan una perspectiva diametralmente opuesta a la de Claudia en el asunto del amor. Es decir, que ellos sufren por la ausencia de la mujer amada (Claudia para Rubén y La Mora para Gilberto) porque ellos si se entregaron al sentimiento que ella les inspiró. Rubén y Gilberto representan a aquellos que todavía se debaten entre la espera y la desesperanza, los que se entregan a la ilusión, aunque se arriesguen a perder lo que han encontrado. De hecho, ambos han perdido a Claudia/La Mora. Pero a pesar del dolor que experimentan, aún son capaces de ilusionarse con el amor, vivirlo, perderlo, sufrirlo y volver a esperarlo. La prueba está en la nostalgia que les provoca hablar de ella. Lo curioso es que aunque ellos consideran a Claudia culpable de la tristeza de ambos, no es por el daño que ella les haya causado sino por todo lo positivo, lo bello y lo espiritual que ha dejado en sus vidas. En ellos no hay arrepentimiento, sino resignación.

Queda claro que el tema del hambre afectiva en esta novela presenta una complejidad extraordinaria. Los personajes viven en un limbo afectivo donde los sentimientos son una suerte de reliquia que se guarda con recelo. Es amor a medias, pues hay temor de dar y recibir. $\mathrm{Y}$ es ahí donde entra en juego el erotismo, aspecto que desempeña una función redentora, ya que es la única forma viable de saciar temporalmente el hambre afectiva. Podemos plantear la llegada fortuita del Erotismo,

\footnotetext{
${ }^{4}$ En su obra L'être et le néant, Jean Paul Sartre presenta una serie de conclusiones que indican el carácter contradictorio y masoquista del amor: "Plus on m'aime, plus je perds mon éter [. . . ]. Le réveil de l'autre est toujours possible, il peut d'un moment à l'autre me faire comparaître comme objet: de là la perpetuelle insécurité de l'amant [....]. Il faudrait être seul au monde avec l'aimé pour que l'amour conserve son caractère d'axe de référence absolu. De là la perpétuelle honte [. . . ] de l'amant" (445).
} 
príncipe azul o caballero andante que viene al rescate del Hambre, damisela encerrada en la concebida torre del castillo. El erotismo adorna el espacio narrativo de esta novela porque es el único adorno permisible dentro de un entorno árido. El erotismo actúa en función de su capacidad redentora ya que, como afirma Manuel Gahete Jurado, el erotismo puede ser el principio de toda teoría que hermana la búsqueda incesante de un Dios que nos invoca, la unión del alma humana con su creador (149). Sólo cuando se logra esa comunión, es posible la comunicación entre el hombre y la mujer y entre los seres humanos en general.

Aunque muchas veces el erotismo está estrechamente ligado a la sexualidad, en este texto se establece una clara distinción entre ambos. Los encuentros sexuales de La Mora (nombre de guerra de Claudia) con los turistas, en especial el primero, llevan a su distanciamiento espiritual. En el momento del acto sexual su cuerpo y espíritu se separan: "Y alguien la desnudaba, y ella no oponía resistencia cuando le abrían las piernas... y sentía que la alzaban por la cintura y la penetraban... Lo dejó hacer, como si aquel acto no tuviera relación con su cuerpo" (149-50). Cabe notar que el encuentro con el cliente es unilateral, Claudia se distancia de lo que está viviendo y su participación en el acto es puramente física, y por eso no es una simple coincidencia que la voz narrativa deshumanice el momento del clímax. El sexo a cambio de dinero carece de todo valor humano y de todo erotismo, lo cual impide que durante la entrega corporal se produzca la también la entrega espiritual ${ }^{5}$.

\footnotetext{
5 Existe una gran similitud entre Claudia, alias La Mora, y Sailín la jinetera del cuento "Putas en miniaturas" de Jorge Alberto Aguiar visto en el capítulo anterior. Sailín sabe que el sexo por dinero carece de todo valor espiritual. Por eso se niega rotundamente a tener una relación sexual con JAAD, pues sabe que él sí la ama. Claudia por su parte puede vender su cuerpo a los turistas, pero no logra entregarse espiritualmente a Gilberto porque sabe que el amor que él siente por ella requiere reciprocidad.
} 
Pero hay en el texto otros encuentros sexuales, en los que los participantes experimentan una suerte de alivio y de liberación espiritual. El primer encuentro sexual entre Claudia y Rubén se describe de la siguiente manera. "Más que un acto de amor, fue un acto de alivio... El goce de los cuerpos era el reconocimiento de que estaban hechos para la vida y no para la muerte... Sólo aspiraban a saciar su hambre de amor sin tener que pedir permiso" (79). Es evidente que el erotismo aquí es símbolo de libertad; libertad de expresarlo todo, de darse sin reservas, sin secretos y sobre todo, sin miedo. Lo mismo ocurre en una de las regresiones de Claudia a La Habana colonial, donde dentro de la locura y el caos de un carnaval, Claudia tiene un encuentro sexual con el misterioso mulato Onolorio: "Muchas noches había rogado por sentirse libre... y ahora gozaba con aquella entrega donde no existía otro requisito que el propio acto de entregarse... Ahora saciaba su hambre, toda su hambre acumulada" (201). En un mundo como el que se presenta en esta novela, donde el individuo se siente reprimido ya sea por tradiciones, prejuicios o imposiciones políticas, donde hay hambre de todo tipo, miedos $\mathrm{e}$ incertidumbres, la única razón para celebrar la vida es la partícula erótica del ser humano.

Es a través del erotismo que cada uno se entrega plenamente. Él constituye la afirmación de que se es y que no sólo se está, y de que hay un posible estado de permanencia aunque nunca se logre alcanzar plenamente, pues el erotismo es sólo un alivio temporal y no una cura para la carencia afectiva. Alberto Garrandés explica que es una sexualidad que trasciende el sexo mismo, y la define como "una sexualidad 'ecléctica' que nace no tanto (o no sólo) en la búsqueda del placer, o en la búsqueda de articulaciones complejas alrededor del deseo, sino en el yo que ansía comunicarse con el 
otro ávidamente" $(216)^{6}$. Esta definición de Garrandés es evidente en el primer acto sexual entre Claudia y Rubén, mencionado anteriormente, en el que también se pone de manifiesto la teoría de Hugh J. Silverman sobre la función del deseo en el acto sexual: "In the sexual relation, the desire to surrender to the other includes a concomitant desire not to supplant the other" (1). En ese encuentro Claudia y Rubén se deshacen de sus respetivas corazas dejando al descubierto sus sensibilidades, permitiendo así que la entrega se convierta en un acto de rendición y de redención. Entre ellos existe un afecto genuino y por eso la entrega física y espiritual es mutua.

Con esto, se puede concluir que los elementos que conforman el todo en el texto de El hombre la hembra y el hambre giran alrededor de un eje central que es el hambre. La realidad de cada personaje gravita inevitablemente hacia él. Y es que su papel protagónico en este texto, con todas sus manifestaciones y desdoblamientos, demuestra que el hambre en esta novela de Daína Chaviano no es sino una metáfora, acaso la única metáfora posible para lograr la conceptuación de una realidad inexplicable de otra manera. Por ende, catalogar el texto estrictamente como una novela sobre la realidad cotidiana del Período Especial redundaría en una lectura superficial y maniquea. El hombre, la hembra y el hambre son una suerte de trinidad que define la existencia de cualquier ser humano que padezca de carencias. Y aunque este tipo de situación puede darse en todo entorno y momento histórico, el texto de Daína Chaviano presenta una problemática que hasta entonces había permanecido al margen de la literatura cubana de la revolución. Es decir, que se perfila un giro en la temática de la narrativa cubana pues

\footnotetext{
${ }^{6}$ Esta afirmación de Garrandés hace referencia directa a la narrativa de la década de los noventa, época a la que llega luego de realizar una suerte de bosquejo del tema y la función de la sexualidad y el erotismo en la narrativa cubana a partir de 1959. Las bastardillas son de Garrandés.
} 
se desecha el tema del carácter mesiánico de la revolución, para destacar su fallido intento de forjar un hombre nuevo a partir de un único molde. Además, según la propuesta revolucionaria, el Hombre Nuevo no siente hambre de nada porque lo tiene todo. Pero en este entorno, donde el Estado se ha convertido en enemigo, cada cual tiene que saciar su hambre personal. Daína Chaviano presenta al hombre (y la hembra) como tales, y aunque los muestra en toda su imperfección revolucionaria, también revela su caótica perfección humana. El hombre, la hembra y el hambre se aparta del tema del ciudadano ejemplar realizado y satisfecho con su labor revolucionaria, para explorar las complejidades y carencias de todo ser humano.

\section{Distancia y lejanía: La nostalgia del exilio y del insilio}

Quien haya experimentado el exilio sabe que en éste suele producirse una ruptura en la que resultan perjudicadas ambas partes: la que se va y la que se queda. Como indica Paul Ilie, "[E]scision is a reciprocal relationship [. . .]. A deprivation occurs in both directions, for while the extirpated segment is territorially exiled from the homeland, the resident population is reduced to an inner exile. Each segment is incomplete and absent from the other" (2-3). El exilio, que en la narrativa cubana de la revolución había permanecido como tema tabú, comienza a cobrar importancia a partir de la época del noventa, momento en que se empieza a aceptar en la literatura la existencia de "los de aquí y los de allá", algo que en sentido general no es muy común pues el tema del exilio se aborda mayormente desde una perspectiva unilateral. Al respecto Ilie nota: "Rarely has anyone wondered about the hollow effect left after the exodus, about the repercussions upon those citizens who shared emigré values but who remained in the homeland" (3). De ahí la importancia de explorar la problemática del exilio tomando en cuenta ambas 
partes. Como afirma el personaje de Marcela, en Café Nostalgia (1997), "[L]as personas estarán obligadas al exilio, pero sus sombras quedan [ . . .]. Siempre habrá alguien de aquel lado que guarde un espacio para cobijar nuestras huellas debajo del ramaje de las ceibas" (176). Discutir el tema del exilio requiere de una aproximación bilateral. Si, por ejemplo, se observara solamente la perspectiva de Marcela en París y se excluyera el punto de vista de los insiliados Don Fuco, Victorio y Salma en La Habana de Los palacios distantes (2002), el análisis sería parcial y plano, se estaría obviando la complejidad del asunto.

La narrativa cubana de la revolución, como se ha visto en el primer capítulo, ha respondido con el pasar de los años a la postura gubernamental, sobre todo en cuanto a sus temas. Desde inicios de la década del sesenta el exilio ha sido un tema sumamente escabroso en la política revolucionaria El que partía, abandonaba automáticamente su papel de compañero, convirtiéndose en "gusano" o "escoria", digno del "acto de repudio", para luego desaparecer del todo. Como afirma Ambrosio Fornet, "[E]l que se iba, dejaba de existir, simplemente; desaparecía de mi vista y de mi vida; se convertía en un fantasma" (3). No es sorprendente entonces que esa ausencia se refleje en la literatura y que los escasos textos que sí discuten el exilio lo hagan de manera bastante maniquea y unilateral. Un texto que explora esta temática al principio de la era revolucionaria es Memorias del subdesarrollo (1965) de Edmundo Desnoes, quien en la frase inicial del texto resume toda una actitud frente al exilio desde la perspectiva del que se queda: 
"Todos los que me querían y estuvieron jodiendo hasta el último momento, se han ido ya" $(1)^{7}$.

Los cambios que se suscitan a finales de la década del setenta repercuten en la manera en que la literatura y el cine comienzan a abordar el tema del exilio. Entre otras cosas, comienza un diálogo entre los del interior y los del exterior propiciado por el Grupo Areíto y la brigada Antonio Maceo. Por consiguiente, esta apertura conciliatoria comienza a hacerse presente en la literatura del momento, a través de textos como Contra viento y marea (1978), un testimonio colectivo del Grupo Areíto, y De la patria y el exilio (1979) de Jesús Díaz, textos ganadores de los premios Casa de las Américas y UNEAC respectivamente, así como el documental de Díaz 55 hermanos (1979). El valor de estas obras radica fundamentalmente en el hecho de que presenta el testimonio de los de fuera, sobre todo aquellos cuyo exilio había sido ajeno a su voluntad por haber abandonado el país desde muy temprana edad. En estos textos se pone en evidencia la necesidad del regreso a las raíces, a la patria que se desconoce y se añora a la vez. Los testimonios que ofrecen estos jóvenes exiliados sobre la experiencia de crecer fuera de Cuba muestran la verdadera tragedia del exiliado que es ser extranjero en su propia tierra, como lo hace Lourdes Casal en su poema "Para Ana Veltfort": "[C]omo ya para siempre permaneceré extranjera / aun cuando regrese a la ciudad de mi infancia" $(11-12)^{8}$. En

\footnotetext{
${ }^{7}$ Cabe notar que la voz narrativa de Memorias no representa al individuo cuya familia abandona el país, y con la que debe romper relaciones por lealtad a la revolución o por miedo a represalias. La ruptura del personaje con su familia poco tiene que ver con la partida de ésta a los Estados Unidos pues se origina en la actitud del personaje frente a todo y a todos los que lo rodean. Sin embargo, lo importante es que la visión que presenta Desnoes del que se va coincide con la actitud oficial, y por ende con la opinión pública.

${ }^{8}$ Eliana Rivero afirma que para Casal, "La Habana es la ciudad-madre, donde radica la identidad, pero Nueva York es una experiencia que habrá de definir para siempre el sentido de marginalidad de la autora" (7).
} 
cierto sentido, estos textos demuestran que el exiliado, a pesar del sentimiento de no pertenecer, abandona un poco su naturaleza fantasmagórica para cobrar identidad.

No obstante, en la década del ochenta, a raíz de la crisis del Mariel, la tensión entre los dos extremos se intensifica. El éxodo del Mariel resulta tan traumático y violento para los que se van como para quienes se quedan y un desengaño para los brigadistas. Las humillaciones públicas, los apedreos y las golpizas en masa que tienen lugar tan frecuentemente en los "actos de repudio" de esta época resultan igualmente dañinos para quienes los reciben como para los que los propician. Se trata sin duda de un momento histórico de intensos cuestionamientos morales y de profunda reflexión sobre el tema de la ruptura humana y de la difícil reconciliación. Ésa es la problemática que predomina en la narrativa de la época, y que representa el desencuentro. La idea recurrente en los textos estudiados parece coincidir con el argumento de Gustavo PérezFirmat cuando dice: "Lección de exilio: el único regreso posible es hacia adentro, no hacia atrás" (51). Entre los textos que se producen en estos años están Mujer que regresa (1986) de Rolando Pérez Betancourt, La espada y la pared (1987) de Gustavo Eguren, así como la pieza teatral Weekend en Bahía (1987) de Alberto Pedro. Todos ellos forman parte de un vasto repertorio de desencuentros, que Ambrosio Fornet cataloga de “testimonios de una época y radiografías de uno de los traumas más dolorosos y persistentes de nuestra sociedad" (7).

En la narrativa de los noventa se observa, como bien explica Josefina Ludmer, una nueva perspectiva de lo que constituye el exterior. Según Ludmer, en esta literatura se produce "un deseo/una necesidad del exterior de la nación [. . .]. El exterior deseado puede ser cultural-literario o lingüístico y no solamente nacional-territorial. En síntesis: 
los personajes se sitúan en el exterior/interior de la nación, de la sociedad y de la ley, y en un juego narrativo específico: adentro y afuera de sí mismos" (364). Partiendo de esta clasificación interior/exterior de Ludmer, este apartado se dedicará a estudiar dos formas de exilio que se manifiestan en la narrativa cubana de esta época, y que aquí serán clasificadas como "exilio", que implica un desplazamiento geográfico, e "insilio", que implica un estado mental de alienación, de exilio interno. Son numerosos los nexos que pueden discutirse y que de hecho se discutirán entre el exilio y el insilio, pero el más importante de esos nexos es la nostalgia. La experiencia de la nostalgia se produce tanto en el que se va como en el que se queda, precisamente a causa de la ruptura (ya sea geográfica o mental) que ocurre en ambos casos.

En este apartado se exploran dos aproximaciones al tema del exilio, una es la de Zoé Valdés en Café nostalgia (1997) y la otra la de Abilio Estévez en Los palacios distantes (2002). Hay varios elementos contrastantes entre ambas novelas en cuanto al acercamiento de sus autores al tema. Primero, la trama de Café nostalgia se desarrolla en París; es decir que Marcela, la protagonista, se encuentra en un exilio geográfico. Los palacios distantes, por otra parte, tiene lugar en La Habana y sus personajes principales, Don Fuco, Victorio y Salma, viven en una suerte de insilio, o sea que sin abandonar la ciudad han dejado de vivir en ella sicológicamente. Sin embargo, muy a pesar de estos contrastes, también existe entre ellos un denominador común que es la nostalgia. Este estudio tiene como objetivo demostrar que tanto en el exilio de Marcela como en el insilio de Don Fuco, Victorio y Salma el papel protagónico le corresponde a la nostalgia. Con tal objetivo en mente, también se explorarán diversas teorías sobre el concepto de la nostalgia, tema que muchos ven como un fenómeno puramente espacial y otros como uno 
puramente temporal. Dichas teorías explican asimismo aspectos específicos del exilio y la nostalgia, demostrando así que estos temas no aparecen en la narrativa del Período Especial como simples conceptos abstractos, sino que se exploran de manera específica e individual, de acuerdo con las circunstancias que rodean a cada personaje.

El argumento que aquí se presenta defiende la noción que la nostalgia, aunque contenga un innegable aspecto espacial que se presenta a través de la distancia, es principalmente una noción temporal representada por la lejanía 9 . Esta noción de la nostalgia del emigrante coincide en cierto sentido con la que sugiere Svetlana Boym: "At first glance, nostalgia is a longing for a place, but it is actually a yearning for a different time --the time of our childhood, the slower rhythm of your dreams" (xv). Guardando las diferencias y los matices, es factible afirmar que tanto los exiliados externos como los internos sufren de una crónica condición nostálgica que gira principalmente alrededor del aspecto temporal.

Marcela, personaje principal de Café nostalgia, es una talentosa fotógrafa que radica en París luego de haber abandonado su país natal, y es además el prototipo del exiliado. En ella se observan síntomas de nostalgia que han sido tema de estudio para muchos críticos literarios, filósofos e incluso, sicólogos. Rafael Rojas, por ejemplo, habla de dos subcategorías dentro de la categoría general de exilio que se observan en el personaje de Marcela. Según Rojas, entre los que han abandonado su país de origen cualquiera que haya sido la circunstancia de ese exilio, "[P]arece haber dos tipos ideales

\footnotetext{
${ }^{9}$ La distinción entre distancia y lejanía ha sido tomada del argumento de Ángel Cuadra en su estudio sobre el tema de lo cubano en la poesía del exilio: "Hay una sutil diferencia entre distancia y lejanía. Distancia se identifica más con la separación física, con lo objetivo en el espacio; lejanía se identifica más con la separación espiritual, el ámbito subjetivo y anímico" (137). Nuestro argumento defiende la noción de que esa separación espiritual subjetiva y anímica constituye el aspecto temporal de la nostalgia.
} 
de exilio: el de quienes viven en la antesala del regreso, [. . . ] y el de quienes encuentran su destino en el nuevo espacio, liberándose de las pulsiones de la espera y el regreso, por medio de la nostalgia, el desencanto o la plena integración al país adoptado" (10). Esta clasificación de Rojas propone, sin embargo, una interrogante fundamental: ¿no padecen de nostalgia ni desencanto aquellos que pertenecen al primer tipo de exilio?

Todo parece indicar, por ejemplo, que Marcela pertenece a ese primer grupo que vive en la antesala del regreso, que espera la transformación del país natal; es decir que aparentemente no ha encontrado en París su nuevo destino, ni parece capaz de integrarse al país adoptado, algo que se observa en dos hechos fundamentales. Primero, Marcela abandona su profesión de fotógrafa para huir de la fama y el reconocimiento que ésta le ha ganado entre los franceses, optando por permanecer en el anonimato, es decir, al margen. Por otra parte cambia de domicilio frecuentemente, hasta que por fin encuentra, en el barrio Le Marais, un ambiente "barriotero" muy similar al de Centro Habana, en el que pasó su niñez y su adolescencia. Marcela vive en una constante y frustrante búsqueda de algo que ya no existe: su infancia. Esta búsqueda se presenta desde el principio de la obra en la cita de Teognis sobre la imposibilidad de capturar la juventud ${ }^{10}$. El hecho de que Zoé Valdés comience la novela con estos versos de Teognis demuestra que Café nostalgia es un texto concebido indiscutiblemente desde la nostalgia. Para resumir en pocas palabras la complejidad del asunto de la nostalgia en esta novela, al menos a

\footnotetext{
${ }^{10}$ La cita es una traducción al francés de un poema de Teognis de Mégara, poeta lírico de la poesía griega arcaica, siglo VI a.C.: "Et je tremble, voyant les amis de mon âge, / car les jeunes, les beaux, les joyeux passeront / Et moi-même avec eux. Hélas, le temps ravage. / Les générations! La jeunesse est un rêve".
} 
manera de preámbulo, recuérdense algunos versos del poema "Lo extraño todo" de Jorge Salcedo: "No es racional, no fueron buenos tiempos / pero lo extraño todo" (7-8) ${ }^{11}$.

Estos versos de Salcedo constituyen una verdadera muestra de cómo Zoé Valdés percibe y experimenta la problemática de la nostalgia del emigrante, una aproximación que va en contra de varias teorías, como la de Fred Davis, por ejemplo. Davis afirma que la nostalgia se centra en la belleza, el placer, la alegría, el amor, en fin los aspectos positivos del pasado, y que rara vez estos recuerdos del pasado incluyen sentimientos negativos como la infelicidad, la frustración, la desesperación, el odio, el abuso y la vergüenza (14). O sea, que según Davis, el individuo tiende a idealizar el pasado, posiblemente debido a su inconformidad con el presente que le ha tocado vivir. Sin embargo, en el texto de la Valdés el asunto principal es precisamente la nostalgia por un pasado mayormente doloroso, y sobre todo traumático para la protagonista. Como afirma Carlos Domínguez-Espinosa, en esta novela "recorremos [. . .] los tramos más significativos de la existencia de Marcela, quien echa sobre esos años una mirada a veces entrañable, a veces melancólica, siempre crítica" (250). Es decir, que en las constantes remembranzas de La Habana de su infancia, las cuales constituyen gran parte del texto, no se produce, al menos de manera evidente, una distorsión de los hechos recordados. La prueba está en que los eventos del pasado encajan como piezas de rompecabezas en los recuerdos de Marcela (pasado) y en los descubrimientos de Samuel (presente). Asimismo, esos eventos del pasado, como los recuerda Marcela, carecen del carácter

\footnotetext{
${ }^{11}$ El poema "Lo extraño todo" pertenece a la colección Naufragio y sedición en la isla de Juana.
} 
idílico que le adjudica David Krell a la memoria ${ }^{12}$. De hecho, la inadaptabilidad de Marcela al nuevo medio y su incapacidad de ser feliz se deben precisamente al carácter traumático de numerosos sucesos que tuvieron lugar en su infancia, como el abandono de los padres, la violenta muerte de su amante platónico, la pérdida de la virginidad, y el aborto, entre otros. Marcela recuerda esos hechos como ocurrieron, y precisamente porque no se produce en su memoria ninguna distorsión embellecedora, los recuerdos la atormentan y le impiden adaptarse al presente.

Uno de los elementos centrales en Café Nostalgia lo constituyen los textos de Marcel Proust, ya que en ellos radica el carácter temporal de la nostalgia de Marcela. Proust y su obra se convierten en el leitmotif de este texto pues a través de toda la novela Marcela se refugia en la lectura de sus obras. Es importante destacar, sin embargo, lo que verdaderamente significan las lecturas de Proust para Marcela, y en qué sentido éstas constituyen un refugio para la protagonista. Como se ha dicho anteriormente, Marcela se niega a toda posible adaptación al presente. Su inestabilidad domiciliaria y laboral demuestran la necesidad de mantenerse al margen y de no incorporarse del todo al nuevo milieu, lo cual significaría, desde su punto de vista, una ruptura total con el pasado. A las mudanzas y los cambios de empleo como mecanismos de defensa contra el olvido, se suman las lecturas de Marcel Proust. Básicamente, Marcela y Proust comparten, además del nombre, la obsesiva necesidad de escapar del presente en un despiadado intento de revivir un pasado irrecuperable.

12 David Krell afirma lo siguiente en su estudio Reminiscence and Writing: "Memory has a way of transforming any content into a wondrous appearance, bathing even the most traumatic event in a soothing light" (xii). 
Los amigos de Marcela, que tanto le reprochan las lecturas de Proust y su afán por aferrarse al pasado, mantienen, o al menos aparentan mantener una actitud del segundo tipo planteado por Rojas; o sea el que encuentra su destino en el nuevo espacio. Por eso critican vehementemente a la amiga que se aísla y que prefiere permanecer al margen incluso de ellos. Y es que esta actitud de Marcela frente a sus amigos de la infancia, su costumbre de no contestar el teléfono ni abrir la correspondencia se debe más que nada a que ellos ya han dejado de pertenecer al pasado, pues han optado por aceptar el inevitable paso del tiempo y el traslado geográfico, y por lo tanto han dejado de existir en el estado mental que ella no logra abandonar. El contraste entre Marcela y sus amigos la echa aun más hacia el margen donde ella se instala sin objeciones. La actitud de los amigos representa el otro extremo del continuo nostálgico: la crítica del recuerdo ${ }^{13}$.

Pero el hecho de que el pasado sea irrecuperable hace que la búsqueda continúe y que se repita precisamente por su carácter infructuoso. Es decir, que se produce una circularidad nostálgica que, según Todorov, es irrompible. Ese enfermizo estado de vigilia es lo que busca Marcela para aferrarse a su estatus de inadaptada, para sumirse y regodearse, como afirma el propio personaje, en esas crisis depresivas que terminan por producir en ella una suerte de catarsis para sobrevivir en el inevitable presente parisino. Marcela es, por ende, el perfecto ejemplo del emigrante de Todorov, en cuyo caso "to remember the old country, the old way of life, then becomes a matter of commitment and responsibility toward the self, not toward a place" (125). O sea que la nostalgia de

\footnotetext{
${ }^{13}$ Estas contrastantes actitudes frente al recuerdo, que corresponden con los dos tipos de emigrantes que Rojas presenta, se observan en otros textos como Informe contra mí mismo, donde las cartas de los amigos de "Lichi" critican severamente su afán por recordar el pasado: "No sigas con ese libro. De nada vale recordar. De nada. Recordar no es volver a vivir [. . .]. Recordar es volver a mentir" (70). "Lo que logras con tus reflexiones es hacer leña del árbol caído, alimentar el falso fuego de la memoria" (114).
} 
Marcela no es justamente por "Aquella Isla" como le llama a su país natal, sino por ella misma, por su propio yo de otrora. Eso lo corrobora el personaje cuando, explicando la necesidad de mudarse, dice: "Cuando el bichito interno ordena que debo renovar, es preciso obedecer al presentimiento. Eso tendrá que ver, es posible, con la incesante búsqueda de mi irrecuperable sitio en el mundo, el universo de mi infancia" (203).

El brevísimo regreso de Marcela a Cuba como fotógrafa de un negociante francés cumple con una importante función en la trama: demostrar que la nostalgia, incluso en el caso del exiliado, es un fenómeno más temporal que espacial. La experiencia inicial, la salida del aeropuerto, es el primer indicio: "Al salir de ese espacio de nadie, de esa frontera tan terrible por el daño psíquico que causa, y entrar y pisar el reblandecido pavimento, respiré mi tierra a pleno pulmón. ¡Cristo, olía a infancia, a amigos!” (117). Su presencia en la isla elimina el factor espacio, y sólo resta la melancolía por un tiempo pasado. Sin embargo, el olor a amigos e infancia no pasa de ser un falso presagio puesto que más tarde la protagonista se da cuenta de que aunque ella ha regresado a Cuba, la Cuba de sus recuerdos no está ahí para recibirla. La experiencia de Marcela en su corta estancia en la isla ilustra varias de las teorías que se han formulado sobre el tema del regreso. Una de ellas es la de Malcolm Chase y Christopher Shaw, quienes notan: "The home we miss is no longer a geographically defined place, but rather a state of mind" (1). Aprovechando una pausa en su agenda laboral, Marcela logra escabullirse y visitar los lugares que no ha querido olvidar a través de sus años de exilio: "Pude escaparme hasta el Malecón [. . .] me zumbé hasta Santa Cruz del Norte, de regreso deambulé por la desolada y derruida Habana Vieja. Estuve llorando frente a mi casa, después recorrí las direcciones de mis amistades idas" (117). Sin embargo, ninguna de estas visitas logra 
aliviar la nostalgia de Marcela, sino que en efecto la exacerban cuando ésta se da cuenta de que aunque ha efectuado un regreso geográfico, nunca logrará el regreso temporal. Es por eso que reflexionando sobre su corto viaje afirma: "Había regresado y no, ya que no podría contar nada porque nada había hallado, salvo miseria, amargura y ausencia" (117).

Es evidente que el exilio en el texto de la Valdés produce una nostalgia en la que el aspecto temporal prevalece sobre el espacial. Y curiosamente, Abilio Estévez, autor de la novela Los palacios distantes, describe cómo experimenta la nostalgia durante una corta ausencia de Cuba. Para Estévez, como para Marcela, la nostalgia no es por La Habana que ha abandonado apenas dos o tres años antes, sino por la de su infancia, que aparece en sus recuerdos como una infancia feliz. Lo importante en su caso es que aun sin saber a ciencia cierta si tal felicidad es real o una simple jugarreta de la memoria, su nostalgia no es espacial sino temporal: "No sé si lo que me reclama es la ciudad mentirosa literaria del recuerdo, llamada 'mi infancia', que no está en ningún sitio geográfico, sino en el lugar mucho más recóndito de mis afectos" (Sin miedo 1). Esta experiencia personal del autor, donde la nostalgia se perfila como un sentimiento de añoranza por un escurridizo estado mental recuperable solamente a través de la memoria es la que queda plasmada en Los palacios distantes.

En esta obra, el autor explora una nueva dimensión de la temática del exilio. Para comenzar, es necesario aclarar que el exilio, en cuanto a desplazamiento geográfico se presenta en el texto sólo de manera casi casual. El padre de Salma se ha ido a los Estados Unidos y su hermano a Italia. Pero nadie sabe con certeza dónde están ni si las noticias que se comentan esporádicamente sobre ellos son reales o sólo invenciones de Salma y su madre. El aspecto del exilio que constituye el eje central de esta novela es uno 
completamente diferente al desplazamiento geográfico, y tiene que ver únicamente con el desplazamiento sicológico y anímico; es decir, con el insilio o exilio interno. Recordemos que los tres personajes principales de la novela viven en La Habana y que no se van de allí, o sea que no existe desplazamiento geográfico.

Por otra parte, es necesario entender el título de la novela de Estévez para obtener una mayor comprensión del asunto que aquí nos ocupa. Victorio, uno de los personajes principales y al que ya nos hemos referido, vive atormentado por el recuerdo de un antiguo mentor: el Moro. Además de la atracción que de niño sentía por aquel joven que le doblaba la edad, Victorio recuerda que el Moro le dio la lección más importante de su vida: "Gracias a él tuvo y tiene la certeza de que en algún lugar existe un soberbio palacio que lo espera [. . ¿] ¿Tú no sabes que todos tenemos un palacio en algún lugar? [. . .]. Cada persona nace con un palacio asignado, para que viva en él y para que en él se realicen caprichos, gustos, aspiraciones" (24). Pero para Victorio lo fundamental en la teoría del Moro es que aunque todos tengan un palacio asignado, muchos nunca lo encuentran. Por lo tanto, cree fielmente en el poder de la imaginación y en la capacidad mental del individuo para transportarse a ese lugar idílico que le es negado materialmente. En otras palabras, el palacio no es sino aquel rincón de la imaginación donde el ser humano se siente realizado y feliz. Para el Moro, su palacio es "una casita en una colina, rodeada de mangos, nísperos, mameyes [.. . ] y una vaca y un caballo, ah, y un pozo [. . . ] los árboles son verdes-verdes-verdes y las flores rojas-rojas" (24). La certeza de que existe ese palacio y de que sólo hay que proponerse encontrarlo constituye la base de lo que se define como insilio. 
Existen numerosas teorías acerca del insilio o exilio interno, y éstas, como se ha dicho, reflejan la manera particular en que cada personaje vive esta experiencia. Por ejemplo, Paul Ilie señala su carácter negativo al decir que el exilio interno se define como "the isolation endured by distinct groups vis-à-vis an entire culture. It is, further, a partial asphyxiation of the entire culture" (47). Observando el caso de Don Fuco, Victorio y Salma en cuento a la definición de Ilie, es posible percatarse del contraste entre sus respectivas situaciones frente al entorno social de cada uno. Don Fuco, por ejemplo, es un pobre viejo, un payaso que deambula por hospitales, funerarias, cementerios y asilos de ancianos haciendo reír a la gente con sus acrobacias y actos de magia. Este personaje se perfila como un ser casi mítico, una suerte de aparición, pues nadie sabe quién es ni de dónde viene. Victorio, por su parte, es un cuarentón homosexual que vive sólo en un edificio que está a punto de ser demolido. A juzgar por el texto, nunca ha tenido una relación amorosa ni amistosa, con la excepción de su ya fallecido amigo el Moro. Frente a la inminente destrucción de su paupérrimo edificio, Victorio destruye todos sus recuerdos y pertenencias, y con una mochila a la espalda comienza a deambular por la ciudad. Por último, Salma es una joven jinetera que vive en un mísero cuartucho con su madre ciega. La muerte de su madre, conjuntamente con el recrudecimiento de las amenazas y golpizas de su proxeneta Sábanasagrada, hacen que Salma, sola y aterrorizada, decida huir y desaparecer.

Estos tres personajes son individuos marginados y alienados como los describe Ilie, pero su alienación se produce mucho antes que su exilio interior. Contrario a lo que argumenta Ilie, el insilio es precisamente lo que salvará a estos personajes de la 
alienación en la que ya viven ${ }^{14}$. O sea, que si bien es cierto que Don Fuco, Victorio y Salma han dejado de ejercer sus funciones como ciudadanos ellos experimentan voluntariamente esa marginación. El suyo no es el insilio que se le adjudica, por ejemplo, a los miembros de la oposición política en la isla, sino que son ellos quienes prefieren vivir al margen de la sociedad. De hecho, el margen es el único sitio donde verdaderamente logran existir. El insilio que experimentan estos personajes muestra mayor correspondencia con el análisis de Daniel Chango, en el que indica que el insilio es "aquel estar sin ser dentro de la propia patria de uno que a uno se le presenta enajenada, pero no enajenada exclusivamente en lo socioeconómico, sino en el sentido de lo destinal, en el adónde va todo" (1). Y es precisamente esta distinción entre el ser y el estar que sirve como base para el estudio del insilio en este texto. Don Fuco, Victorio y Salma están (viven) en la ciudad pero son (existen) fuera de ella, en un antiguo teatro que a pesar de estar en plena ciudad, nadie parece percatarse de su existencia.

El escenario principal de la novela es el antiguo teatro El Pequeño Liceo de La Habana, que ha burlado el paso de los años y el control de las autoridades. Es un espacio cuya función temporal lo convierte en una suerte de trampolín del que se lanzan los tres personajes para alcanzar sus propios palacios distantes. Pero este teatro, repleto de reliquias y recuerdos de antaño, espacio común compartido por los tres desamparados, representa algo diferente para cada uno de ellos. Para concretar la plurivalente función del teatro en ruinas, es necesario entender de dónde vienen los personajes que terminan por congregarse en él. Don Fuco es, si se quiere, la vida y voz del pasado glorioso que

\footnotetext{
${ }^{14}$ Cabe destacar que José Ismael Gutiérrez coincide con Paul Ilie en cuanto a lo que constituye la fuerza motriz del insilio. Para Gutiérrez, "el insilio implica la prohibición para el ser humano [. . .] de ejercer sus funciones ciudadanas y lo condena a la marginación, al ostracismo, a la prisión o a la disidencia" (xvii).
} 
representa ese espacio. $\mathrm{Y}$ es él quien atrae a Victorio y a Salma hacia dicho espacio. El teatro es el palacio (no distante) de Don Fuco: “¿Qué le parece? [. . .]. [É]ste es mi palacio, como puede ver, discípulo de Baudelaire, vivo aquí desde hace muchos años, y no creo que haya nadie en el mundo más dichoso" (99). El teatro es la metáfora de un pasado glorioso e irrecuperable, pero es, a la vez, la realización concreta de la nostalgia.

Don Fuco es un personaje tan atemporal como el teatro. En el texto se observa una serie de incongruencias históricas que le otorgan al espacio y al personaje que lo representa un carácter irreal. Según cuenta Don Fuco, el teatro se construye por orden de la princesa rusa Marina Voljovskoi. Entre las numerosas incongruencias que presenta el recuento de Don Fuco, está el hecho de que, según él, la princesa llega La Habana "a principios de este siglo XIX" (104), y que luego de numerosos viajes a Cuba, es en 1917, a causa del triunfo de los bolcheviques, que decide permanecer en la capital cubana. La princesa, que al parecer tenía fuertes inclinaciones artísticas de todo tipo, sintió la necesidad de construir un pequeño teatro sin fachada de teatro, para recibir a grandes figuras del ámbito que ofrecían funciones a la princesa y sus íntimos amigos, artistas entre los que se encuentran Anna Pavlova, Sarah Bernhardt, María Callas, Enrico Caruso, Cora Vaucaire y Alicia Alonso. La constante alusión a legendarias figuras artísticas le dan tanto al teatro como a Don Fuco un carácter misterioso, haciendo que surja un sinnúmero de interrogantes: ¿Es Don Fuco un hombre de carne y hueso, o acaso una aparición, un espíritu? ¿Cuál es la relación entre Don Fuco, un simple payaso, y una princesa rusa que lo invitaba a presenciar todas las funciones que los grandes artistas ofrecían en su honor? ¿Es acaso un loco? Porque, según afirma Jacobo Machover, “[E]l 
autor crea una poética de la soledad y la demencia" (3). ¿Se referirá acaso a la soledad de Victorio y Salma y a la demencia de Don Fuco?

Sea cual sea la naturaleza de Don Fuco, él representa sólo una cosa, el pasado glorioso que se vivió en ese teatro. Asimismo, el teatro, por muy ilusorio que parezca, sí contiene reliquias que demuestran la veracidad de las palabras del payaso. Desde las marionetas del Guiñol, la tumba de Giselle y el blanco piano de cola del escenario, hasta el vestuario y los objetos del montaje son pruebas contundentes de que el pasado que evoca Don Fuco es real ${ }^{15}$. Además, es probable que las incongruencias y cabos sueltos de la historia de Don Fuco se deban a la idea de Frederic Bartlett de que "el recuerdo está afectado por transformaciones inconscientes, siendo el recuerdo exacto la excepción y no la regla. Cuando se visualiza el recuerdo suele haber confusión en el orden de presentación. Y también, el efecto transformativo de actitudes afectivas aumenta con el lapso de tiempo ocurrido" (61).

La realidad o irrealidad histórica del teatro y hasta del propio payaso carece de importancia, porque lo que sí es crucial en este texto es la función de ambos en las vidas de Victorio y Salma que, pese a que aparentan ir en retirada, van en busca de algo. Ya se ha mencionado que, antes de llegar al teatro, Victorio vive solo en un cuartucho de un edificio que está a punto de derrumbarse. Vive una vida de miseria y necesidades de todo tipo, principalmente afectivas. Victorio es la muestra de lo que María Luisa Negrín define como "un sentimiento de no pertenecer, en el que el ser humano se siente sin asideros y que conlleva una actitud crítica y el cuestionamiento existencial; la enajenación es una

\footnotetext{
${ }^{15}$ Don Fuco menciona otras reliquias, las que cataloga de "verdaderas reliquias de la patria" (134), pero que ni Victorio ni Salma ven jamás. Algunas de estas reliquias son los vestidos de Rita Montaner, de Barbarito Diez, de Benny Moré; lienzos de Portocarrero, Amelia Peláez y Tomás Sánchez, e incluso el mantel ensangrentado de los Lamadrid sobre el cual murió Julián del Casal.
} 
suerte de exilio interior" (xviii) ${ }^{16}$. Pero dentro de toda su pobreza y aislamiento, Victorio logra mantener vivos ciertos recuerdos que, de una forma $u$ otra, le permiten enfrentarse a la precariedad del diario vivir. Entre los preciados objetos que posee Victorio están las fotos de Rodolfo Valentino, Johnny Weismuller, Freddie Mercury y el Moro. Todos ellos, piensa Victorio, "[H]an quedado fijos en belleza eterna" (22).

Por otra parte, la reproducción de la pintura El embarque para Citerea de Jean Antoine Watteau es para Victorio una suerte de llamado a abandonar la realidad y dejarse arrastrar hacia una imagen de fantasía. La obra maestra de Watteau presenta una típica fête galante de la aristocracia francesa de la época. Lo interesante de esta pintura es que no se trata de una fiesta como las acostumbradas, sino de un peregrinaje hacia la isla sagrada de Citerea, una especie de paraíso inalcanzable adonde los Cíferos habían llevado a Venus después de su nacimiento. La presencia de esta pintura en el mísero cuarto de Victorio es primordial porque demuestra que incluso los más ricos aristócratas de una fête galante tratan de llegar a un mítico e inalcanzable sitio. Así que desde muy temprano en el texto ya se presenta la temática de la búsqueda de algo inalcanzable, de la evasión y el escapismo. $\mathrm{Y}$ eso es precisamente lo que hace Victorio todas las mañanas, si bien no logra cambiar su trágico entorno: trasladarse a un universo desconocido para él.

Siguiendo entonces, las enseñanzas del Moro, Victorio tiene el poder de transportarse a una hermosa casa mallorquina al borde del mar Mediterráneo sin abandonar el rincón de su cuartucho inmundo. La imaginación de Victorio es tan prolífera como la de su mentor. La casa mallorquina de Victorio es "un caserón; palacio

\footnotetext{
16 Ésta definición de la enajenación del individuo aparece en un estudio de Negrín sobre la obra de Reinaldo Arenas. El personaje de Victorio posee muchas de las características de los personajes arenianos, incluyendo al propio Arenas, principalmente por su homosexualidad, condición que dentro de la doctrina revolucionaria significara un camino directo hacia la marginación.
} 
amplio, espacioso, lleno de luz [. . .]. Al final del salón principal un ventanal acristalado deja paso a una terraza que se abre al Mediterráneo" (29). Como llevado de la mano por el espíritu del Moro, encuentra su palacio distante. En su visita al palacio de Mallorca, Victorio ve "una suntuosa mesa servida, un desayuno excepcional: jugos de frutas, mermelada de arándanos, croissants recién horneados, jamón de Jabugo, café de Colombia" (29). Su imaginación no sólo se vierte sobre la belleza del lugar, sino que también logra visualizar deliciosos manjares, mientras bebe un café que sabe "a ropa sucia y un trozo de pan del día anterior" (28).

Salma, por su parte, posee la misma capacidad para trasladarse a su mundo ideal sin abandonar su mundo real de la calle. Debajo de un torrencial aguacero, con los zapatos rotos y el cuerpo empapado por la lluvia, Salma le describe a Victorio el universo al que aspira llegar alguna vez. Para comenzar, hay que recordar que su verdadero nombre es Isabel, pero que utiliza el nombre de Salma porque su sueño es llegar a ser una famosa actriz de Hollywood como Salma Hayek. Con toda certeza y convicción, Salma le cuenta a Victorio que ella canta en un teatro repleto de gente con su propio conjunto musical, que lleva lujosos trajes de los más famosos diseñadores, y que por su genial actuación en una película acaba de ganarse un Óscar. En la entrega de premios imagina "no poder hablar de la emoción, llorar, abrir los brazos con la estatuilla en alto, decir a ese público que [la] adora, que [la] ovaciona senquiuverimoch, ailofyu" (50). El poder imaginativo de Salma es tal, que incluso se queja de que la ceremonia la ha dejado extenuada y que por suerte su novio Andy García, "un actorazo [que] nació en Bejucal" la espera afuera (50). De hecho, Salma espera que Andy García y Victorio se conozcan un día. Salma sufre de una seria condición de bovarismo, algo que se torna sumamente 
peligroso para la joven debido a la alta imposibilidad de realización de esa vida imaginaria en su entorno cotidiano. La fantasía juega un papel fundamental en la vida de estos dos individuos en cuanto a su función de refugio pues sólo dentro de esa fantasía logran escapar brevemente de la apabullante realidad. Como afirma Luis Camargo, "[L]a fantasía debe ser sostenida (tal es su condición) más allá [. . .] de sus probabilidades de concreción, pues es en ella donde los sujetos hallan un refugio vital, en la medida en que sus nutrientes son las representaciones de los espacios que en otro momento brindaran las satisfacciones pretendidas" $(2)^{17}$.

El comienzo del insilio es diferente para Victorio y Salma, pero la circunstancia es la misma porque ambos lo han perdido todo. Victorio sale de su cuarto, luego de destruir sus posesiones, a excepción de la foto del Moro. Abandona su puesto laboral y se dispone a deambular por las calles de La Habana, convertirse en uno de los tantos desamparados, y con eso pretende escabullirse y pasar inadvertido. Como afirma Jacobo Machover, "la única alternativa es huir o sobrevivir como se pueda, escondiéndose en algún recinto al resguardo de las intemperies [. . .]. Le queda la memoria, o mejor dicho, lo que le fue transmitido por los mitos y leyendas engendrados en La Habana" (2). Su llegada al teatro es casi accidental, ya que sale huyendo de una pizzería del Barrio Chino de donde se ha ido sin pagar, y en la huida se encuentra con el payaso, a quien sigue hasta el Pequeño Liceo de La Habana.

La llegada de Salma al teatro, a raíz de su reencuentro con Victorio y Don Fuco, ocurre también por casualidad, pues tiene lugar en el cementerio de Colón, donde Salma

\footnotetext{
17 Este planteamiento presenta acaso una contradicción y es su mención de "los espacios que en otro momento brindaran las satisfacciones pretendidas." Ni las fantasías de Victorio ni las de Salma pertenecen a antiguas experiencias, sino que son estrictamente producto de la imaginación de ambos, imágenes basadas en experiencias (reales o ficticias) vividas por otros.
} 
acaba de enterrar a su madre. Allí están Don Fuco y Victorio para asistir al entierro de una amiga del primero. Ahora, en un momento tan trágico en la vida de esta joven, ella encuentra en los dos hombres una tabla de salvación para no hundirse del todo en la soledad, el miedo y la enajenación que la hostigan. Don Fuco, por su parte, funciona como una Ariadna sui generis, cuyo hilo va guiando a Salma y a Victorio dentro de su teatro laberíntico hacia un nuevo destino, hacia un exilio que no es más que un exilio interior. Sin abandonar La Habana, "Victorio aprecia lo lejana, [. . .] que se halla la ciudad [. . .] nada de lo que allá afuera acontece perturba la paz del teatro devastado, como si el teatro, y ellos con él, flotaran en un espacio sin espacio, dimensión ilusoria sobre la isla ilusoria del continente ilusorio del planeta ilusorio" (101). El teatro constituye un insilio por varias razones. Primero, porque es el único refugio al que pueden acudir estos seres que ya no encuentran cabida en una ciudad que tampoco pueden abandonar. Asimismo, en ese sitio maravilloso y fantasmagórico Victorio y Salma se encuentran con su yo verdadero, el yo que ha permanecido reprimido y que saldrá a la luz, a través de la magia de Don Fuco, que no es sino "un payaso que les abre las puertas de un palacio fabuloso, salvado de la destrucción, revelándoles a la vez los secretos del mundo y del pasado" (Machover 2). Por último, este espacio, a través de las remembranzas de Don Fuco, provoca en los ellos la nostalgia, sentimiento que va de la mano del exilio, aun cuando se trata de una nostalgia por experiencias ajenas.

Recuérdese, sin embargo, que como indican Chase y Shaw, se necesitan tres condiciones básicas para que se produzca la nostalgia: el sentido lineal del tiempo, el miedo al presente, y la evidencia del pasado (4). En cuanto al sentido lineal del tiempo y el miedo al presente, los tres personajes presentan tales condiciones; por ende, la 
nostalgia en ellos se produce como el mecanismo de defensa al que se refiere Andrea Ritivoi: "I see nostalgia as a defense mechanism designed to maintain a stable identity by providing continuity among various stages of a person's life" (9). La interrogante surge en cuanto a la tercera condición: la evidencia de un pasado (bueno o malo). Don Fuco es una excepción porque de hecho si una sola de las condiciones se cumpliese en él, sería precisamente la evidencia del pasado. Pero el caso de Victorio y Salma es diferente porque en ellos hay un gran vacío en el "espacio" que debería estar ocupado por el pasado. Al parecer en ellos se produce un proceso inverso al que experimenta Don Fuco, ya que mientras éste se alimenta de los recuerdos y de las experiencias vividas o imaginadas, Salma y Victorio parecen huir de las suyas propias.

Victorio, por ejemplo, recuerda con cariño al Moro y a su madre. Sólo los momentos vividos con estas dos personas le causan nostalgia y todo lo demás lo recuerda con marcada indiferencia. Hay una vivencia en particular que demuestra la actitud indiferente de Victorio hacia su niñez. Recuerda imágenes como el agua verdosa y mugrienta, salpicada de sargazos, el ir y venir de la familia escandalosa, la yuca con mojo de aceite y ajo, el lechón asado y la espumadera de la abuela que brilla dentro del arroz congrí por la manteca de puerco (40). Pero ninguna de estas imágenes trasciende al plano afectivo. La nostalgia que este recuerdo provoca en Victorio poco tiene que ver con la playa, ni con ratos de diversión, y mucho menos con familiares queridos, sino con lo que representa para él la inocencia de la infancia, pero la infancia como etapa en la vida de cualquier individuo, y no la suya en particular: "Ha regresado a ese territorio de la infancia, de la irresponsabilidad feliz, donde no existen derrumbes, enfermedades, 
torturas, envejecimiento, ni muerte. Deduce que en esta comarca dichosa no hay lugar para la maldad" (40).

En cuanto a Salma, una joven nacida dentro de la era revolucionaria, la mirada hacia el pasado es casi nula. Salma carece de infancia a causa de circunstancias como el abandono del padre, la ceguera de la madre, la apabullante miseria en que siempre ha vivido su familia, la prostitución de su hermano y la suya propia. Por lo tanto, la joven sufre de vejez prematura, de manera que su corta edad demuestra esa mezcla de sabiduría y desilusión de un anciano que ha sido maltratado por la crueldad de la vida, y que ya va en retirada. De hecho, el único recuerdo grato que comparte con Victorio es el descubrimiento de su sexualidad y del placer experimentado en ese descubrimiento, placer que no experimenta al prostituirse. El resto de su vida anterior aparece como una especie de cortometraje que Salma narra más como testigo de esa vida que como protagonista. ¿Por qué se produce entonces la nostalgia en individuos que buscan huir del pasado? La respuesta puede estar en que tal vez ellos no deseen necesariamente romper con al pasado, sino con los recuerdos que no les resultan agradables, que son la mayoría, ya que ninguno de los dos ha tenido una infancia feliz ${ }^{18}$. O tal vez no se trate de revivir los momentos de felicidad, sino de la necesidad de encontrar un pasado, aunque no sea el suyo propio. Esta búsqueda del pasado ajeno, que en cierto sentido responde a la filosofía de que "todo tiempo pasado fue mejor", ilustra el argumento de García-Posada de que en esta novela el pasado tiene la sola función de refugio: "El pasado aquí sólo existe para refugiarse en él huyendo de la lamentable realidad" (2).

\footnotetext{
${ }^{18}$ La nostalgia, aun en casos como los de Victorio y Salma, es un fenómeno indispensable, que David Lowenthal define como "a perpetual staple of nostalgic yearning in the serach for a simple and stable past as a refuge from the turbulent and chaotic present" (21).
} 
Don Fuco es quien demuestra que la nostalgia se produce como un fenómeno témporo-espacial. Ya se ha visto que el teatro abandonado constituye el espacio, pero un espacio que pertenece al pasado por dos razones. La primera son los objetos que allí permanecen como si el teatro hubiese quedado suspendido en el tiempo, por lo que los detalles históricos carecen de importancia. La segunda razón es que en ese espacio Don Fuco ha logrado encapsular un pasado que de otra manera sería irrecuperable. En cierto sentido, Don Fuco, más que recordar el pasado, vive en él, o al menos trata de permanecer en él. Por eso continúa ensayando sus números de acrobacia y vistiéndose con los disfraces de antaño, e incluso logra que Victorio y Salma lo acompañen es estas andanzas. Sin embargo, a pesar de todos los gratos momentos y gloriosas funciones que perduran en la mente del payaso, éste reconoce la imposibilidad de recuperar ciertas cosas. Y aunque las "reliquias de la patria" que todavía yacen intactas en el teatro le demuestran que todavía puede vivir en ese tiempo, hay ciertas cosas que Don Fuco considera irrecuperables, como el sabor del níspero, el olor de la lluvia, el rocío en el valle de Viñales, el llanto de algunos que se echaron al mar en 1994 y las trágicas despedidas en los aeropuertos (134-35). Todos esos elementos representan la verdadera carencia del exiliado ya que en ausencia de reliquias, como las que pululan por el teatro de Don Fuco, los recuerdos se esfuman de la memoria del anciano. Y es ahí precisamente que la nostalgia se convierte en un fenómeno temporal. Podría decirse, entonces que la nostalgia, más que añoranza de un pasado que se recuerda y que no se puede revivir, es la necesidad de aferrarse a los recuerdos de ese pasado, recuerdos que se desvanecen sin remedio con el paso del tiempo. 
Don Fuco se aferra a sus reliquias porque éstas no escapan a su memoria al estar encerradas entre las paredes del teatro; es decir, que forman parte del espacio, no del tiempo. La agonía de Don Fuco se debe a una responsabilidad que se impone a sí mismo de recordar aquellas cosas que ya no existen y que se disuelven a pasos agigantados en su memoria. El payaso vive en una batalla constante contra el olvido, y se empeña en recordar para ganarle la batalla al tiempo: "Si pudiera comer pan de semillas untado en aceite de oliva. Sólo eso le bastaría para vivir, pan con aceite de oliva, aceitunas bien aliñadas, y un buen tinto, por supuesto, reserva de las riberas del Duero [. . .]. Brillan las pupilas nostálgicas de Don Fuco, las manos se alzan en un falso gesto de placer" (127). Falso es el gesto de placer de Don Fuco porque todos estos alimentos que añora, forman parte del pasado irrecuperable. No obstante, insiste en recordar y libra una batalla contra el enemigo implacable que es el olvido: "Qué fatigoso, demasiado sí, demasiado difícil habitar en el País-del-Olvido, y al propio tiempo luchar contra él, contra el olvido [. . .]. En este país padecemos todos los tipos posibles de olvido [ . . ] ¡Es preciso recordar! usted sabe, el olvido semeja un virus, un maleficio de la sangre" (130).

Don Fuco es consciente de que la lucha contra el olvido es inútil, pero no se rinde porque él carece de presente para crear nuevas memorias. Para él, el olvido significa la muerte, y reconoce su enorme desventaja frente al tiempo y el olvido, desventaja que describe Pérez-Firmat: "El exiliado busca un techo que lo ampare del tiempo, en ambos sentidos, aunque sabe que su empresa es vana: contra el tiempo no hay morada. Imposible demorar el tiempo" (19). Es por eso que el payaso no se rinde en esa lucha tenaz. Por eso necesita de Victorio y Salma, cuya función es recibir de manos del payaso una especie de herencia de la memoria. De hecho, Don Fuco se abandona a la muerte sólo 
cuando se da cuenta de que ha dejado sus recuerdos, o más bien el hábito del recuerdo, en buenas manos y de que ha salvado a Victorio y a Salma del olvido. Victorio y Salma pasan entonces a ocupar una suerte de estatus oficial de exiliados dentro de su propio país, ya que como afirma Pérez-Firmat, los exiliados "viv[en] del recuerdo de una vida que no [han] vivido y de la esperanza de una vida que no [han] de vivir" (33).

El exilio provoca una ruptura, una brecha infranqueable entre los que se quedan y los que se van, y sobre todo entre lo que se queda y lo que se va. Y esa ruptura se debe ante todo, al destiempo que se produce entre ambos grupos. Después de la partida, sólo puede producirse el desencuentro pues, aunque el que se va insista en revivir el pasado, el que permanece en el espacio no lo hace temporalmente, sino que avanza hacia su propio presente. Es como si ambas partes tomasen interminables caminos paralelos en el tiempo. La ruptura que representa el exilio se explica a través del concepto de tiempo nacional de Enrique del Risco, quien nota que "si para los cubanos de la isla su tiempo nacional es el agotador presente, la experiencia del tiempo nacional para los de extramuros se divide entre un pasado cada vez más remoto y un futuro nunca lo suficientemente cercano. El tiempo nacional queda así escindido y su reparación improbable" (167).

Es curioso notar que tanto Marcela como Victorio y Salma encuentran, cada uno a su manera, la forma de remendar la ruptura del exilio y el insilio. Marcela lo hace reconciliándose con los recuerdos del pasado que hasta ahora la atormentaban. Victorio y Salma, por su parte, asumen y aceptan de manos de Don Fuco la existencia de un pasado que hasta ahora les era ajeno. Pero el denominador común, el lazo que une a todos estos personajes es, indiscutiblemente, la nostalgia que, a pesar de ser la enfermedad, la carencia, la ausencia de, es también el remedio. O sea que la única opción con que cuenta 
el individuo que, dentro o fuera, carece de poder para cambiar su situación actual es la nostalgia.

Los textos que ocupan este capítulo tienen en común un aspecto fundamental ya que reflejan el giro que ha tomado la narrativa cubana a partir de la década de los noventa en cuanto a las temáticas que en ellos se exploran. No existen en estos textos, escritos tanto dentro como fuera de Cuba, héroes revolucionarios dispuestos a darlo todo por la causa de la revolución. Daína Chaviano, Zoé Valdés y Abilio Estévez rescatan a los personajes literarios del encasillamiento en que se encontraban en décadas anteriores para otorgarles vida y voz propias, para entregarles su individualidad. Los personajes de estos textos dejan de seguir los estrictos paradigmas revolucionarios para convertirse en simples seres humanos cuyo padecimiento principal es la carencia. Y es a través de nuevas temáticas como el hambre, el exilio y la nostalgia que los autores logran conceptuar los diversos matices de esa carencia.

El hambre de todo tipo, al igual que la nostalgia que producen el exilio y el insilio, representan la necesidad insatisfecha de los personajes de los textos analizados. Cabe destacar que si en Los palacios distantes y en Café Nostalgia los personajes se aíslan de la sociedad a través del exilio y del insilio, El hombre, la hembra y el hambre también termina con una fuga por mar que seguramente será trágica. De cualquier forma, estos personajes — ahora independientes — buscan algo que la revolución no ha podido darles. Los textos parecen sugerir que el resultado directo de la revolución cubana no ha sido el Hombre Nuevo, sino el anti-Hombre Nuevo, el gusano, el desertor. Sin embargo, es importante recordar que los personajes abandonan su papel de ciudadanos revolucionarios, no por la influencia de un pasado burgués ni por falta de fervor 
revolucionario, sino porque el descreimiento adquiere un carácter universal en estas obras. Los héroes revolucionarios de las décadas anteriores al Periodo Especial han desaparecido, dejando en su lugar un enorme vacío, una carencia que ha aniquilado toda esperanza en el futuro. 


\section{Capítulo IV}

Resurgimiento del pensamiento crítico en la narrativa del Periodo Especial

Los elementos discursivos y temáticos de la narrativa cubana del Periodo

Especial constituyen un comportamiento literario que refleja actitudes específicas del individuo frente a la decadencia de su entorno. Si existe una actitud dominante tanto en el contexto histórico-social del Periodo Especial como en su narrativa es el desencanto que, como afirma Damián Fernández, tiene un carácter moral: "The greatest disenchantment perhaps was not the material one caused by the breakup of the Soviet Union but the moral one, because the revolution was supposed to be, above all, a spiritual renovation of the nation" (79). Tal desencanto, no obstante, implica una actitud de inconformidad y de rebelión que el individuo se ve obligado a expresar de una forma u otra, y una de esas formas de rebelión es el cuestionamiento. Por eso, la narrativa que surge en la década de los noventa y que aún continúa produciéndose en Cuba constituye la realización de un pensamiento crítico hasta entonces vedado en la literatura de revolución, la materialización del cuestionamiento que surge como consecuencia directa del desencanto ${ }^{1}$.

Respecto a la temática del desencanto y su recurrencia en la narrativa que se desarrolla en Cuba durante la década del noventa, Leonardo Padura afirma que hay una innegable relación entre éste, como parte de la realidad cubana del momento, y la noción del cuestionamiento en la narrativa cubana: "Es una literatura esencialmente crítica de la

\footnotetext{
${ }^{1}$ Fernández explica el origen del desencanto frente al proyecto revolucionario cubano afirmando que "the gap between theory and practice, promise and delivery, has cost the regime legitimacy and support. For many the revolution has become a failed utopia. Another modern project that came to naught [. . .]. By the 1990 s the signs were clear that the Cuban regime had been unable to reproduce the necessary emotional infrastructure to guarantee legitimacy and governability" $(79,83)$.
} 
realidad actual, de los comportamientos humanos y de procesos sociales ocurridos en el país. Una literatura que también está revisando determinados asuntos históricos recientes" (Epple 53). En este capítulo se presentan algunos aspectos que indican el resurgimiento del pensamiento crítico, en el que los autores intentan, desprenderse de algunos principios dogmáticos tan arraigados en la literatura de la revolución, aunque no siempre lo logren del todo. Estos autores intentan urgir al lector y a sí mismos al cuestionamiento, a reconocer tanto el desencanto y la desilusión, como el insipiente espíritu de búsqueda y descubrimiento de nuevos caminos e ideales.

En el primer apartado de este capítulo el enfoque está dirigido a La novela de mi vida (2002) de Leonardo Padura, texto que constituye un llamado al cuestionamiento de la historia oficial. El segundo apartado presenta el cuestionamiento de ciertas fallas del proyecto revolucionario cubano, a través de un estudio comparativo entre Las palabras perdidas (1992) de Jesús Díaz y El vuelo del gato (2000) de Abel Prieto. Los tres textos que ocupan este capítulo revelan tanto el poder del escritor para proponer el cuestionamiento como la capacidad del lector para ponerlo en práctica. El denominador común entre las novelas de Padura, Díaz y Prieto es el hecho que el desenlace queda en manos del lector. La lectura de cada una de esas novelas constituye para el lector el ejercicio del pensamiento crítico, de manera que los tres autores exigen que el lector cree su propia hipótesis y decida qué mensaje va a extraer de cada lectura, exigencia que representa a su vez el ejercicio de la libertad de pensamiento. 


\section{La novela de mi vida:}

\section{Función del perspectivismo y la ficción en el cuestionamiento de la historia oficial}

En La novela de mi vida, Leonardo Padura Fuentes presenta la biografía del escritor decimonónico José María Heredia, y mediante la yuxtaposición de múltiples perspectivas, algunas que corresponden con la historia oficial y otras que divergen de ella, el autor funde realidad con fantasía para crear nuevas realidades. Crea mediante ficciones confluentes una nueva versión de la historia, haciendo de la vida de Heredia una novela. Como indica el propio autor, "[l]a existencia real del poeta y de los personajes que lo rodearon, [. . .] ha sido puesta en función de un discurso ficticio en el que las peripecias reales y las novelescas se entrecruzan libremente" (La patria 11).

El texto se desarrolla en tres niveles narrativos, comenzando por la autobiografía de José María Heredia, la que revela como es de esperarse, una visión introspectiva. El segundo nivel presenta la vida de José de Jesús, hijo y último albacea de Heredia, quien ofrece una óptica retrospectiva de la vida del poeta. El tercer nivel gira alrededor de Fernando Terry, intelectual cubano exiliado en España que estudia la vida y obra de Heredia a finales del siglo XX. Empero, la existencia de tres niveles narrativos no indica que sólo haya tres perspectivas porque en cada uno de estos niveles confluye un sinnúmero de aproximaciones que no se limitan a la vida del poeta, pues van más allá de lo personal para explorar aspectos sociales, políticos y literarios, desde la primera mitad del siglo XIX hasta finales del XX. En este apartado se persigue demostrar que la aproximación perspectivista del texto actúa como vehículo para en el cuestionamiento de la historia oficial cubana. 
La autobiografía de Heredia sale a la luz mediante unos escurridizos manuscritos que lo conectan con su hijo José de Jesús y a éste con Fernando Terry. Desde la aproximación introspectiva de Heredia, el lector obtiene una imagen, real o ficticia, de la vida, la obra, las pasiones, los sufrimientos y las flaquezas del poeta, y mediante esta óptica se presenta además un panorama de la realidad de la Cuba colonial. El texto autobiográfico revela toda una visión de La Habana de la época, la temprana inclinación de José María Heredia por la poesía, su amistad con Domingo Del Monte y otros intelectuales del momento, sus inquietudes políticas, sus penurias en el exilio, y sus dos grandes pasiones: Lola Junco y $\mathrm{Cuba}^{2}$. Heredia asume por lo tanto el papel de autor, voz narrativa y protagonista de su propia novela, en la que el tema de La Habana y de la sociedad capitalina de la época colonial cobra gran importancia. Si bien Heredia presenta diversas facetas de La Habana que manifiestan el poder seductor de la ciudad, la capital es, a su vez, un reflejo nada idílico de la sociedad cubana del momento.

Los matices costumbristas que tanto abundan en la literatura decimonónica cubana se observan claramente en el texto de Padura cuando Heredia describe varias facetas de la vida en La Habana. Algunas de estas facetas son el baile de los cabildos de negros en la vieja plaza de Armas frente al palacio de los Capitanes Generales, las calles enlodadas o empolvadas según la época del año, el tráfico caótico de carretas, quitrines y volantas y el peligro de ser atropellados por uno de ellos, y sobre todo, la creciente industria de la prostitución. Así se expone la temática de la prostitución desde la perspectiva de Heredia: “[E]sa noche aprendí cómo la industria de la prostitución

\footnotetext{
${ }^{2}$ Dolores Junco no aparece en las biografías que se han escrito sobre José María Heredia. Leonardo Padura crea este personaje para presentar un idilio amoroso que comienza antes del matrimonio de Heredia con Jacoba Ibáñez, y que perdura a pesar de la distancia impuesta por el destierro.
} 
prosperaba en la isla más que la fabricación de azúcar, y cómo el negocio era especialmente provechoso en la modalidad de las esclavas fleteras, [. . . pues aquellas infelices tenían como norte comprar su libertad..." (32). Cabe notar que gran parte del caos que se vive en La Habana de la época colonial se debe, entre otras cosas, al imperante sistema esclavista, causante del alto número de negros en la ciudad y en la isla en general.

En la narración de Heredia, la crítica a la esclavitud se produce mediante alusiones veladas, adoptando incluso un matiz burgués que se nota cuando Heredia, al presenciar el baile de los negros del Cabildo, dice que "la infamante trata de esclavos había convertido a los negros y mulatos en la mayoría de la población del país," y que éstos tenían la fuerza pujante para "revertir el destino de la isla, como unos años atrás había sucedido en la próspera Saint Domingue" (28). Las observaciones de Heredia dejan entrever el temor a una rebelión que imperaba en Cuba, especialmente entre los poderosos miembros de la sacarocracia cubana. Pero muy a pesar de la presencia amenazante de los negros en la ciudad, de los vicios y de la prostitución, La Habana ejerce sobre Heredia un poder subyugante que él recordará, incluso después de muchos años de ausencia: "[E]l olor perdido de La Habana me late en el pecho con la intensidad dolorosa de la novela que ha sido mi vida, donde todo concurrió en dosis exageradas: la poesía, la política, el amor, la traición, la tristeza, la ingratitud, el miedo, el dolor, que se han vertido a raudales, para conformar una existencia tormentosa que muy pronto se apagará” (20).

La inclinación hacia la creación poética y el talento de Heredia se perfilan desde el principio de su narrativa, a la par del comienzo de su amistad con Domingo Del Monte, 
joven escritor que más tarde llegaría a convertirse en el líder de la intelectualidad literaria cubana de su época. Pero esta amistad luego le produciría emociones complejas y contradictorias, y a través del recuento autobiográfico, presenta a Domingo como un personaje tozudo y manipulador. Desde joven, dice Heredia, Domingo demuestra una gran capacidad para argumentar y justificar sus acciones y un pragmatismo que linda con el cinismo: “¿Ves, José María, lo que es este país? [. . .] Esto es una feria, un circo, una mentira de país. Se supone que esto es lo mejor de Cuba. Pero aquí sólo importa figurar y tener dinero, que te vean y hablen de ti, o de lo contrario, no existes... Lo peor de todo es que aquí la gente no quiere ser lo que es" (28). Asimismo, Heredia se presenta como víctima de las manipulaciones de Del Monte, desde inocentes banalidades juveniles hasta la traición que lo lleva al destierro, cuando se le acusa de conspiración contra el gobierno.

Por ejemplo, a raíz de cierta delación, las autoridades descubren la conspiración del grupo de los Rayos y Soles de Bolívar, y los nombres de los presuntos implicados, entre ellos Heredia. A pesar de su carta al juez instructor, en la que niega su participación en tal conspiración, Heredia se ve obligado a huir a los Estados Unidos, para luego ser definitivamente condenado al exilio. La traición cometida por Del Monte se descubre en la entrevista entre Heredia y el Capitán General Miguel Tacón. En dicha conversación, Tacón humilla a Heredia, acusándolo de cobarde por utilizar su enfermedad y su familia para lograr el permiso temporal de regreso, de iluso por creer que su obra poética podría tener algún efecto en la situación política de la colonia, y de estúpido por creer en la lealtad de su supuesto amigo Domingo Del Monte. En unas cortas frases resume la traición: "Su amigo Domingo se le ha escondido, ¿verdad? Pues no lo lamente. Ese 
hombre nunca fue su amigo. Él fue el que lo delató en el año 23, después de que usted le contara que estaba conspirando" (316).

Pero por otra parte, Domingo Del Monte desempeña un papel importante en la vida intelectual y política de José María Heredia, pues es él quien propicia el encuentro entre Heredia y el padre Félix Varela, contacto que luego se convierte en una estrecha relación en la que comparten la tragedia del exilio. Lo que comienza como un interés por el conocimiento poético del presbítero se convierte en un despertar a la realidad cubana, una preocupación por el futuro del país y un deseo de independencia que marcarán el derrotero que ha de tomar la vida del poeta. La palabra de Varela se convierte en vaticinio, ya que le asegura al poeta que su vida será una de intenso dolor: "Usted va a sufrir desprecio y rencor, y seguramente va a ser traicionado muchas veces, aunque también escuchará elogios y será querido y laureado: trate de hacer oídos sordos a esos cantos de sirenas y a los aullidos de los lobos" (50).

Varela se convierte en un modelo a seguir para el joven Heredia, fundamentalmente por su activa participación en el ámbito político del país. La voz narrativa de Heredia asegura que los jóvenes intelectuales del momento, incluso aquellos de tendencias liberales como Félix Varela, tienen una preocupación fundamental por la identidad nacional, algo que todos pretenden crear y mantener a través de la literatura. No obstante, la independencia es un tema escabroso, aun para los más liberales. Para Varela, por ejemplo, el objetivo es lograr cambios internos en la isla sin que llegue a producirse una revolución, un innecesario derrame de sangre. Heredia comparte el entusiasmo de Varela, pero se trata de un entusiasmo ingenuo ya que él no alcanza a comprender la complejidad de la situación por la que atraviesa Cuba en el año 1821, a raíz de su regreso. 
Al parecer, Varela y Heredia y otros jóvenes intelectuales del momento como Del Monte, Suárez y Romero y Echeverría dan por sentadas las buenas intenciones del restablecimiento de la Constitución de 1812, hasta que al fin reconocen, al menos en el caso de Varela y Heredia, que tal suceso no ha sido más que una estratagema real para realizar "oportunistas cambios políticos para ganar tiempo y reparar los barrotes de su Estado opresivo y volver a segar los leves espacios de libertad concedidos" (72). Como se observa en la cita anterior, ésta es una perspectiva sobre la situación de Cuba como colonia de España y de la actitud de los cubanos frente a tal momento histórico que coincide grosso modo con la que dicta la historia oficial.

La preocupación de la intelectualidad cubana de la Cuba decimonónica frente al futuro de Cuba no es la única visión a la que Padura le otorga voz en este texto. Heredia presenta también la óptica española a través del personaje del Capitán General Miguel Tacón, quien expresa con vehemencia su posición frente al tema del destino de Cuba, explicando, de paso, su papel como gobernante en ese destino: "Este país tiene sobre sí los ojos de los Estados Unidos y de Inglaterra. Y si se abre una brecha, sería el fin. Si para conservar la isla como española hay que acallar los reclamos políticos de unos cuantos, pues los acallamos. De los males, el menor. Eso es política y realismo" (314). Al regresar a Cuba, después de trece años de exilio, Heredia comprende que su sacrificio por la patria ha sido en vano y que su labor como poeta y como cubano carece de toda trascendencia. Pero la trágica imagen que Heredia tiene de sí mismo también está relacionada con la opinión que guardan de él sus antiguos amigos. La voz de los viejos camaradas como Tanco y Echevarría se escucha a través de la intervención de Blas de 
Osés $^{3}$. Aunque Heredia se muestra desconfiado frente a la declaración de Osés de que sus amigos lo consideran un traidor, el documento que le muestra Osés es una prueba irrefutable. Heredia se convierte en el "ángel caído", título que le otorga Domingo Del Monte y que él asume con la poca dignidad que le resta.

La mirada de Heredia hacia su entorno es, a la vez, una mirada introspectiva. Su visión, tanto de la sociedad cubana del momento como de las tierras que le sirven de refugio durante su penoso exilio es asimismo un análisis personal. En ese sentido, el entorno es tan importante como el personaje. Es como si el individuo fuese sólo un reflejo de aquello que le rodea, y de hecho, Heredia es precisamente eso: un espejismo de su tiempo, una imagen que él mismo va recreando en cada renglón de sus memorias y que luego se distorsiona en las referencias de su hijo. En este nivel hay una amplia multiplicidad de perspectivas que funden el presente con el pasado, a la vez que muestra una gran diversidad de puntos de vista sobre una problemática central, creando así diferentes versiones de la misma.

José de Jesús Heredia entra a La novela de mi vida solitario y enfermo. Al final de su vida enfrenta un reto moral y ético, pues tiene en su posesión los manuscritos de la novela de su padre, y lo atormentan las tres opciones con las que cuenta para deshacerse de ellos. La primera es esconder los manuscritos en la Cámara Secreta de la logia

\footnotetext{
${ }^{3}$ José Antonio Echevarría, Blas de Osés y Félix Tanco eran miembros activos del círculo delmontino, un grupo de aristócratas intelectuales cubanos liderados por Domingo Del Monte en la Cuba del siglo XIX. Blas de Osés le muestra a José María una carta que le escribiera Félix Tanco a Domingo Del Monte luego de hacerle una visita a Heredia. En dicha carta Tanco se hace vocero de la opinión que al parecer comparten todos los miembros del círculo delmontino sobre el poeta. La misiva de Tanco, que forma parte del Centón epistolario de Domingo Del Monte, dice: “He visto y abrazado a José María. 'Rentré dans ce cloaque'. Lo abrazaba y sentía vergüenza, sentía indignación, sentía lástima. Lo veía como un desertor, como un tránsfuga abatido, humillado sin poesía, sin encanto, sin virtud [. . .]. [T]odos los amigos y enemigos de nuestro pobre muchacho José Ma piensan del mismo modo que pienso yo, y piensas tú y piensan todos los que tienen vergüenza" (cit. en Cairo 155-56).
} 
matancera Hijos de Cuba. José de Jesús sabe perfectamente que si en algún sitio es posible la absoluta discreción es entre sus hermanos masones. Asimismo podría vender los manuscritos para mejorar su precaria existencia. Después de todo, según recuerda, ya lo ha hecho con otros documentos ${ }^{4}$. Sin embargo, la opción de vender los manuscritos implicaría un grave acto de desacralización de su padre, tanto por el contenido comprometedor de los manuscritos como por la afrenta que tal venta representaría a la memoria del poeta, ya que si opta por venderlos José de Jesús no podría evitar la publicación de los mismos. La posibilidad de vender los manuscritos para ayudar a sustentarse lo agobia hasta la agonía: "[Y] el espíritu de su padre, desde el cielo, de seguro se lo habría perdonado... Pero José de Jesús también conocía que el sabor amargo de la traición cometida no lo iba a dejar morir en paz" (35). Además, el gran temor de José de Jesús es que con la venta de los manuscritos cambiaría toda una visión de la historia, no sólo la de su padre y su familia, sino también la de sus contemporáneos.

La ironía de su temor es que José de Jesús ya ha hecho varias cosas que, de hecho, han cambiado esa historia. Comenta, por ejemplo, que ha destruido dos importantes documentos ${ }^{5}$ : uno de ellos es la carta que José María Heredia escribe a Francisco Hernández Morejón, juez de instrucción de la causa de los conspiradores de 1823, retractándose de su participación en la conspiración de los Soles y Rayos de Bolívar. Se le explican al lector los motivos de José de Jesús para destruir tal documento: "[S]usurró

\footnotetext{
${ }^{4}$ Los documentos que ha vendido José de Jesús son dos cartas que Heredia escribe a Domingo Del Monte desde su destierro, donde "prácticamente lo acusaba" de haber delatado la conspiración independentista de 1823. José de Jesús ha vendido las dos misivas a Domingo Figarola Caneda, director la Biblioteca Nacional en las décadas de 1910 y 1920, y quien además edita los primeros tomos del Centón epistolario (Padura 82).

${ }^{5}$ Cualquiera que haya sido el destino de los documentos en cuestión carece de importancia pues lo que parece importar es la intención del autor de demostrar que la sola manipulación o desaparición de un documento dado puede cambiar drásticamente la historia oficial.
} 
que había quemado la carta para tratar de borrar de la memoria de los hombres la espantosa debilidad mostrada por su padre en aquel dramático momento de su vida" (83). Pero con la sabiduría que se adquiere al ocaso de la vida, José de Jesús se da cuenta de que esa carta no debió destruirse porque demuestra el gran valor de su padre, a quien poco le importó su reputación ni el juicio de la posteridad, con tal de salvar la posibilidad de una existencia feliz con el amor de su vida y con un hijo al que nunca conoció ${ }^{6}$.

El otro documento que José de Jesús destruye es la carta que Heredia envía a Varela en la cual le agradece sus gestiones por publicar su novela Jicoténcal. En esa carta también le pide que la autoría de la novela permanezca oculta, ya que la considera "literariamente fallida" (36). Sin embargo, en este caso José de Jesús no se siente culpable, ya que sólo pretende proteger la gloria literaria de su padre. Además, "[L]o tranquilizaba el convencimiento de que la historia se escribía de ese modo: con omisiones, mentiras, evidencias armadas a posteriori, con protagonismos fabricados y manipulados, y no le producía ninguna turbación su empeño de corregir la historia de su propio padre" (36). José de Jesús asume una actitud redentora de la memoria de su padre, ya mancillada en la opinión pública por otros documentos igualmente comprometedores, como es para muchos la infame carta que Heredia le escribiera a Miguel Tacón en el año 1836. Es la carta por la cual sus antiguos amigos le dieron el apelativo de "ángel caído" y en la cual le habla al Capitán General de "la fama de su carácter íntegro, franco y caballeroso", donde le asegura que "vería como un crimen cualquier tentativa para transplantar a la feliz y opulenta Cuba los males que afligen al continente americano" y

\footnotetext{
${ }^{6}$ Así como la relación entre José María y Lola Junco no aparece entre los datos biográficos del poeta, tampoco aparece Esteban Junco, presunto fruto de esos amores.
} 
donde menciona, además, "los beneficios que su administración íntegra y firme ha dispensado a [su] patria" (cit. en Cairo 152).

Esta carta, de la que José de Jesús y al parecer los propios amigos de José María se sienten tan avergonzados, tiene una función específica dentro del texto, pues en ella se pone de manifiesto cómo un hombre puede valerse de sus palabras para cambiar su circunstancia. Como ha quedado establecido, la razón del destierro de Heredia es fundamentalmente su participación en la conspiración de 1823. Es decir, que su oposición al sistema gubernamental colonial es evidente. Sin embargo, al escribir la carta que ha de asegurarle el permiso para regresar a Cuba por parte de Tacón, Heredia crea una nueva visión sobre la realidad cubana que contrasta sobremanera con su conducta anterior y con sus convicciones políticas. Esta carta que Heredia escribe en la desesperación de no poder regresar a Cuba debido a su precaria salud ejemplifica la presión que ejerce el entorno sobre la expresión del individuo, y demuestra el poder de ese individuo para reinventar la realidad que le rodea. Ese documento lleno de elogios hacia el Capitán General y su desempeño como gobernante de Cuba es lo que único que le asegura a Heredia un efímero regreso a Cuba antes de su pronta muerte.

Por último, José de Jesús cuenta con la opción de destruir los manuscritos. Si eso hiciese, le evitaría vergüenzas y humillaciones a aquellos que, de una manera u otra, están relacionados con la historia que se narra en los manuscritos. Entre los perjudicados están los descendientes de Lola Junco, por lo que José de Jesús trata de evadir su responsabilidad en el asunto entregándole los manuscritos a Ramiro Junco, hijo de Esteban Junco, y nieto a su vez de Lola y José María. No obstante, Ramiro Junco no quiere saber nada de esos documentos: "En Matanzas siempre se habló de Lola y de 
Heredia, pero yo soy Ramiro Junco, y eso ya no lo puede cambiar ningún papel [. . .]. La verdad de Heredia es su verdad, y la mía es la mía" (146-47). En cierto sentido, Ramiro Junco representa una postura que oscila entre la conformidad y la indiferencia. ¿Por qué se desentiende de los manuscritos que podrían demostrar la veracidad de lo que hasta el momento no ha sido más que un rumor? La clave puede estar en su conformidad con la historia oficial, pero la indiferencia puede ser la fachada del temor a enfrentar otras posibilidades que conlleven al cuestionamiento. La conformidad y la indeferencia son posturas que se unen al repertorio de voces dentro del texto, y son tan factibles como las que se han analizado hasta el momento.

Los descendientes de Domingo Del Monte, en especial Domingo Vélez de la Riva, también verían su reputación mancillada si los manuscritos llegan a publicarse. La imagen que se proyecta de su bisabuelo Domingo Del Monte y de su tatarabuelo Domingo Aldama no es la más deseable para su ambiciosa carrera política en la Cuba republicana. Del Monte y Aldama se enriquecen con la trata de esclavos y, en esencia, su postura frente a la esclavitud, como la de muchos otros de su clase, retrasa el proceso independentista cubano en un afán de proteger sus intereses económicos. Domingo Vélez de la Riva sabe que “[p]ara un aspirante a la presidencia de la República,... la difusión de aquellas memorias podía ser un golpe moral, irreparable, que sus enemigos políticos explotarían hasta la saciedad" (285). En el nivel narrativo de José de Jesús Heredia, donde el destino de los manuscritos de su padre decide a su vez el derrotero de la historia, ocurre un hecho inesperado: los manuscritos van a parar a manos de don Ricardo Junco, bisnieto de Lola Junco. Todo parece indicar que Ricardo Junco le ha vendido los manuscritos a Domingo Vélez de la Riva, y el destino final de tan preciados documentos 
ha sido la hoguera. Es decir, que Domingo Vélez de la Riva, bisnieto de Domingo Del Monte y Ricardo Junco, bisnieto de Lola Junco eliminan una parte de la vida de Heredia, escribiendo así una nueva versión de ese período de la historia oficial cubana donde no aparece alusión alguna a los amores entre José María y Lola.

El tercer nivel narrativo de La novela de mi vida tiene lugar a finales del siglo XX. El personaje principal, Fernando Terry, regresa a Cuba luego de varios años de exilio en los Estados Unidos y en España. Este nivel narrativo refleja no sólo la situación actual en Cuba, sino que además realiza una mirada hacia el pasado, dándole a la novela un carácter cíclico. Fernando Terry, quien regresa a Cuba en busca de unos presuntos manuscritos de José María Heredia, se reúne a su vez con sus antiguos amigos poetas: los Socarrones, hombres que en su juventud fueron intelectuales llenos de ilusiones, aspiraciones e inspiración poética. La historia de Fernando Terry y sus amigos desempeña varias funciones en la novela, pero la fundamental es la de proponer, a través de la búsqueda de los manuscritos heredianos, una teoría revisionista sobre la historia de la literatura cubana.

Entre las obras literarias que se cuestionan en el entorno de Fernando Terry está Jicoténcal. Durante una conversación con un antiguo profesor y con su amigo Álvaro, Fernando escucha la teoría del primero en cuanto a la posibilidad de encontrar una novela escrita por Heredia. Según el profesor, la existencia de los manuscritos es altamente cuestionable porque Heredia era poeta, no novelista. Además, no existe ninguna evidencia de tal novela. La autoría herediana de Jicoténcal queda plasmada solamente en la memoria de José de Jesús y en los manuscritos de Heredia, donde el propio poeta dice: 
Por eso me empeñé en concluir, en largas jornadas de escritura, la novela Jicoténcal sobre cuya paternidad siempre guardé el más rígido silencio pues nunca me satisfizo como obra literaria. Sólo Varela, con quien hablé de la idea en Nueva York, sabía de mis intenciones de escribir el relato novelado de la vida del héroe indígena [. . .]. Luego de comenzar y abandonar varias veces aquella obra, decidí retomarla y a finales de 1826 se imprimió en Filadelfia. (225)

A pesar de la información que encontramos en el texto, Luis Leal y Rodolfo J. Cortina adjudican la autoría de la novela a Félix Varela, y presentan además una serie de razones que ponen en tela de juicio la autoría de Heredia. Entre los elementos que discuten Leal y Cortina está el hecho que el propio Heredia critica el lenguaje afrancesado y el uso excesivo del subjuntivo, elementos que están presentes en Jicoténcal. Así que, a pesar del interés que siempre manifiesta Heredia por el tema, la persona más factible para adjudicarle la autoría de Jicoténcal es, según Leal y Corina, Félix Varela (XXV). Sin embargo, cabe notar que en una carta a Domingo Del Monte, Alberto Lisa critica la poesía de Heredia diciendo: "En cuanto al lenguaje, he notado algunas expresiones cuyo origen francés les quita el derecho de penetrar en nuestra poesía: tales como Salud!, por Salve, como han dicho todos nuestros poetas; resorte, cavar el sepulcro y alguna otra" (cit. en Cairo 8). Por consiguiente, si hay indicios de afrancesamiento en el lenguaje de Heredia, lo único que lo separa de la autoría de Jicoténcal es el uso excesivo del subjuntivo en la novela, lo cual no es verdaderamente suficiente para eliminarlo como posible autor. Cabe destacar, sin embargo, que lo importante de todo este cuestionamiento sobre la autoría de Jicoténcal no es precisamente 
la autoría en sí, sino el hecho de que dicho cuestionamiento cumple con la función que le ha dado Padura: crear la duda.

Además de Jicoténcal, hay en la novela otro texto cuyo origen es motivo de polémica. Miguel Ángel, el más suspicaz de los Socarrones y portavoz de la actitud revisionista de sus colegas, está convencido de que Espejo de paciencia no es sino una invención, "una macabra superchería literaria". El Socarrón asegura que el inventor puede haber sido Echevarría, quien presuntamente encuentra el poema abandonado en la biblioteca de la Sociedad Patriótica. Sin embargo, se decide por Domingo Del Monte por el estilo de la escritura, y asegura que "el desfile de frutas cubanas del Espejo es más suyo que los zapatos que traía puestos" (174). Miguel Ángel elabora su hipótesis con las siguientes afirmaciones:

[A]quí se vale inventar los libros que nos hacen falta... ¿No te parece demasiado casual que hayan sido ellos mismos los que se encontraran también por casualidad un poema épico que llevaba dos siglos perdido, del que nadie sabía nada, escrito por un hombre al que se lo tragó la tierra?... Ni siquiera se vio la copia que ellos encontraron... El Espejo es demasiado perfecto, tan perfecto como hacía falta. (174)

La teoría de Miguel Ángel sobre la invención del poema Espejo de paciencia es constatada por la entrevista de Heredia con Blas de Osés, en la que éste le revela el proyecto literario de Domingo Del Monte. El proyecto del círculo delmontino, según Osés, consiste en crear toda una tradición literaria inexistente hasta el momento. Todos los acólitos tienen a su cargo una parte de esta tradición. Unos crean obras sobre la tradición indígena, otros sobre los campesinos, la esclavitud, la ciudad y la historia. El 
objetivo, afirma Osés, es inventar la imagen de un país. Como parte de dicho proyecto, Domingo Del Monte y José Antonio Echevarría habían tomado unas octavas "de un poema de un tal Silvestre de Balboa, donde se contaba el rescate de un obispo [Fray Juan de las Cabezas y Altamirano] secuestrado por unos piratas franceses" (295). Del Monte y Echevarría escribían en ese momento un poema completo para hacerlo pasar como un documento del siglo XVII. Aquí se presenta una irrebatible contradicción, pues según el testimonio de Blas de Osés, el obispo Morell de Santa Cruz, en una especie de historia de Cuba, había copiado "varias octavas que alguien le recitó de un poema de un tal Silvestre de Balboa" (295).

Sin embargo, hay fuentes que presentan una versión diferente a la que se propone en la novela. Por ejemplo, Ángel Aparicio Laurencio indica: "El Espejo de paciencia se conserva porque el obispo de Santiago de Cuba, Pedro Agustín Morell de Santa Cruz, lo copió íntegro y totalmente en su Historia de la Isla y Catedral de Cuba" (8). No obstante, la validez de lo citado depende exclusivamente de la suposición de que Echevarría haya realmente encontrado el poema íntegro en la obra de Morell de Santa Cruz. El problema con tal presunción es que es precisamente sólo eso. Más adelante, en la misma introducción, Aparicio Laurencio indica que “en 1913, José María Chacón y Calvo juzgaba perdido el poema, pero en la edición de 1922 de su Literatura cubana ofrece el dato de que pudo conocer el texto primitivo, 'no ya del poema de Balboa, sino de la Historia de Morell de Santa Cruz..." (8). Si José María Chacón y Calvo pudo ver el texto primitivo de la obra de Morell de Santa Cruz, y ésta no incluía el poema, entonces es obvio que la idea de que el obispo copió el poema íntegro es sólo una teoría que depende únicamente de la credibilidad de José Antonio Echevarría. Tanto la existencia de algunas 
octavas (Osés) como la del poema íntegro (Aparicio Laurencio) no son más que versiones contrastantes de la historia literaria, ambas igualmente plausibles e igualmente cuestionables.

Este acercamiento revisionista no se limita a la autenticidad de Espejo de paciencia, ya que también tiene su propia teoría sobre la producción literaria de Juan Francisco Manzano. Su cuestionamiento gira alrededor de las circunstancias en que se produce la obra del esclavo, sobre todo del papel que desempeña Domingo Del Monte en la misma. Según Miguel Ángel, el interés de organizar una colecta para comprar la libertad de Manzano responde al oportunismo de Del Monte que ya presenta Heredia en sus memorias. El argumento de Miguel Ángel consiste en que Domingo Del Monte ayuda a Manzano a comprar su libertad sólo para adquirir una reputación de filántropo. Dicha teoría, aunque carezca de fundamento histórico, no es del todo desechable. De hecho, la posición de Domingo y la de muchos de sus coetáneos frente a la realidad esclavista cubana del momento es bastante ambivalente, pues enfrentan un conflicto entre los intereses económicos y los principios morales y éticos.

La teoría de Miguel Ángel indica que el apoyo de Del Monte a Manzano responde al hecho de que ni él ni su suegro estaban ya interesados en la trata de esclavos. Es necesario recordar, empero, que Manzano y Del Monte se conocen en el año 1830, y ya en el 1836 Manzano obtiene su libertad (Schulman 31). Bien es sabido que aunque la trata negrera ya había sido abolida, mediante un pacto angloespañol firmado el 23 de septiembre de 1817, la institución esclavista en Cuba era la base de la economía de la sacarocracia. Por consiguiente, sería ilógico proponer que en esos años a Del Monte y a 
Aldama no les interesara la trata de esclavos ${ }^{7}$. La óptica del Socarrón apunta hacia dos aspectos fundamentales. Primero, que los poemas de Juan Francisco Manzano fueron censurados, corregidos y hasta reescritos por Del Monte. Esta manipulación de la obra poética de Manzano, afirma Miguel Ángel, responde al interés de Del Monte en decir sólo lo conveniente y eliminar lo subversivo. Y no es menos cierto que Domingo Del Monte y los de su grupo eran conscientes de los males de una sociedad colonial y esclavista como la cubana. Pero mediante sus acciones él y su círculo pretenden hacer un llamado de conciencia a los dueños de dotaciones, un intento de conmoverlos para lograr una mejoría en el trato de los esclavos para evitar la debacle a la que tantos temen.

Con esa noción del miedo a la subversión y a la censura coincide la hipótesis de Miguel Ángel con la cual trata de explicar la desaparición de la segunda parte de la Autobiografia de Manzano. El Socarrón asegura que en la segunda parte Manzano habría redactado un documento tan subversivo que al ir más allá de correcciones y reescrituras, hubo que desaparecerlo del todo. Sin embargo, no parece haber evidencia que sustente ni documentación que apoye tal opción, por muy plausible que ésta le parezca a Miguel Ángel. Pero aun en ausencia de toda evidencia, insiste en que tanto el encuentro fortuito del Espejo como la desaparición misteriosa de la Autobiografia son producto de la manipulación del círculo delmontino, convirtiéndose así en simples versiones de la historia literaria cubana.

Miguel Ángel es el portavoz del grupo de Los Socarrones, y también lo es de Leonardo Padura. El propio Padura, hablando de la autenticidad de Espejo de paciencia,

\footnotetext{
${ }^{7}$ Aun cuando se generaliza el uso de la máquina de vapor en los ingenios a partir de 1840, la manufactura sigue apoyándose en la misma fuerza de trabajo. Es comprensible, ya que la máquina de vapor se implanta en el trapiche, y al aumentar la capacidad de molienda del ingenio, también aumenta el número de esclavos en las dotaciones de los ingenios (Rivas 28-29).
} 
expresa argumentos muy similares a los de su personaje. Entre otras cosas, Padura afirma que el discurso nacional cubano fue una creación programada como necesidad histórica (La patria 52). Asimismo encuentra sumamente intrigante que el poema esté aderezado con los elementos necesarios, argumento que se observa cuando Miguel Ángel afirma que Espejo es un poema demasiado perfecto. Otros elementos como la ausencia del original y la diversidad estilística entre algunas octavas, aumentan las sospechas de una invención. Pero para Padura la invención no supone graves problemas para la realidad histórica. En su opinión, muchos han reinventado su propia realidad. El ejemplo más importante en que Padura se apoya es el del propio Heredia, señalando que "[m]ás que escribirla, Heredia de alguna manera estaba inventando la patria a la que necesitaba pertenecer, y al inventarla, le daba el soplo divino de la vida que se encierra en las palabras" (La patria 52).

La novela de mi vida puede catalogarse como una novela histórica sui generis. Ésta es, además, una novela cíclica porque, aunque José María Heredia y Fernando Terry pertenezcan a momentos históricos diferentes, muchos son los paralelismos que existen entre ambos. Tal es así que en ciertos momentos de la novela parece que Heredia y Terry se funden en un solo personaje. La traición, el amor frustrado, el destierro, el regreso a la patria, y la agonía frente a una nueva partida son los nexos entre José María y Fernando. Tanto Heredia como Terry vuelven a Cuba en busca de algo: el pasado, la familia, la verdad, los amigos. Y es a través del regreso y la búsqueda que ocurre en la novela una fusión entre el pasado y el presente. Esta fusión del ayer y del hoy se produce por una suerte de conexión espiritual entre ambos poetas. Hay en el texto dos pasajes que demuestran tal conexión. Cuando Terry regresa a La Habana, decide dar un paseo por el 
malecón antes de encontrarse con su amigo Álvaro. Sentado en el muro ve pasar un velero en el que un hombre acodado a la baranda, lo observa fija y persistentemente. De inmediato, Fernando relaciona la imagen del individuo con el recuerdo de Heredia:

Aquel desconocido, que lo observaba con tal escrutadora insistencia, alarmó a Fernando y le hizo sentir, como una rémora capaz de volar sobre el tiempo, el dolor que debió de embargar a José María Heredia, [. . .] cuando vio desde el bergantín que lo devolvía al exilio [. . .] el último recodo de una tierra cubana que el poeta ya no volvería a ver. (17)

Se trata del presente que echa una mirada nostálgica sobre el pasado, y del pasado que mira desesperanzado hacia futuro. En eso consiste el carácter cíclico de la novela. Estas miradas recíprocas hacen su propia reescritura de la historia, ya que borran todo tiempo histórico y toda cronología. Además, al fundir el presente con el pasado, el texto sugiere que la situación actual no es más que una continuación de la historia. De manera que si la revolución promete cambiar la historia, no hace más que repetirla. Hacia el final de las memorias de José María Heredia, éste describe su partida definitiva de la isla. Y en ese episodio se traslada al futuro, al tiempo de Fernando Terry, y ve lo que habría de ser el destino de Cuba. Heredia recuerda haberse acodado sobre la baranda del barco cuando éste abandona el puerto, y desde allí descubre a un hombre que sigue con la mirada el paso del barco:

Por un largo momento nuestras miradas se sostuvieron, y recibí el pesar recóndito que cargaban aquellos ojos, una tristeza extrañamente gemela a la mía, capaz de cruzar por encima de las olas y el tiempo para forjar una 
misteriosa armonía que desde entonces me desvela, pues sé que fuimos algo más que dos hombres mirándose sobre las olas. (332)

La novela de mi vida es, sobre todas las cosas, una novela de la vida, narrada por muchas voces. Es la vida en y a través de la historia, una historia que se repite y se rescribe a cada paso, en cada renglón. Pero en este texto de Leonardo Padura hay mucho más que pluralidad y confluencia de perspectivas porque cada una de ellas es una versión más de la historia que ya ha sido aceptada y asumida como cierta. Con todo esto, el texto de Padura puede considerarse un llamado al cuestionamiento, a no aceptar como definitivo lo que ha quedado escrito en los libros y grabado en la memoria colectiva. A través de una lectura exhaustiva de este texto, el lector tiene la libertad de crear su propia versión de los hechos, por lo que cabe afirmar que el mensaje subyacente a la novela es que cada individuo es un historiador, y que como tal debe desempeñar su función de rescribir la historia a través del simple cuestionamiento de las cosas, a través de la duda y de la desconfianza en lo que ya está escrito.

El aporte fundamental de este texto reside en su divergencia de la novela histórica que se desarrolla en la década de los setenta. Esta novela histórica de Padura difiere de la novela histórica de décadas anteriores en la que el compromiso político es fundamental, pues si hay un elemento básico en La novela de mi vida es que carece de todo compromiso político y que de hecho urge al lector a romper con todo tipo de militancia que no responda a sus verdaderas convicciones. Por otra parte, no se trata solamente de cuestionar lo que ya ha quedado establecido como historia oficial, sino que parte de la premisa de que la historia se escribe y se rescribe en el momento en que se producen los hechos. Padura demuestra el innegable poder de la memoria, las palabras y las acciones 
de cualquier ser humano para alterar toda una visión de la realidad. Además, una idea fundamental que queda establecida en este texto es que la historia siempre cambia en dependencia de la experiencia de quien la cuente, y que precisamente por eso ha de ser cuestionada.

\section{Jesús Díaz y Abel Prieto: Hacia una re-visión del proyecto revolucionario}

Al llegar a autores como Jesús Díaz, fallecido en el exilio en el año 2004, y Abel Prieto, ministro de cultura cubano, el lector puede percatarse de que los textos Las palabras perdidas (1992) y El vuelo del gato (2000) exponen una visión crítica de diversos aspectos del proyecto revolucionario en sí, lo cual constituye un contraste con la aproximación un tanto más simbólica de Padura. Las perspectivas de Díaz y Prieto divergen entre sí en cuanto a su acercamiento al tema del fracaso del proyecto revolucionario, pero coinciden en que ambas apuntan hacia un problema común: la utopía de la creación del Hombre Nuevo. A pesar de las divergencias entre Jesús Díaz y Abel Prieto, ambos escritores exponen un nuevo acercamiento literario al proceso revolucionario, en especial a la cruda y convulsa década de los sesenta. Por una parte Las palabras perdidas de Díaz es una suerte de denuncia y testimonio de la función represiva de la censura gubernamental hacia los artistas e intelectuales, a la vez que pone en evidencia la tendencia al oportunismo y al abuso del poder de ciertos intelectuales que se entregan al juego de la censura con tal de no ser silenciados.

Por otro lado, El vuelo del gato de Prieto lleva a cabo un análisis crítico del proyecto socio-económico y político propuesto por la revolución, pero más que analizar el efecto del proyecto revolucionario en la sociedad, Prieto observa cómo la reacción de la sociedad al proyecto revolucionario ha sido el factor determinante en el fracaso del 
mismo. Con ese objetivo, el autor presenta abiertamente la incapacidad del cubano para asimilar y llevar a la práctica dicho proyecto, y la causa de tal incapacidad es su idiosincrasia. Díaz y Prieto presentan la perspectiva de dos grupos de amigos que echan una mirada nostálgica y crítica sobre sus años de juventud. Nostálgica porque para ambos grupos la década de los sesenta significa una época de inocencia, ilusiones y esperanzas; y crítica, porque ése es el período de mayor intransigencia gubernamental frente al desarrollo de la cultura popular en el país. Durante la década de los sesenta, como explica Armando Añel, "[S]i te dejabas el pelo largo, podías ser acusado de diversionismo ideológico. Si te ajustabas demasiado el pantalón, [ . . .]. Si escuchabas música extranjera [. . .]. Diversionismo implica diversidad. Algo que el marxismo-leninismo, el comunismo o la dictadura del "proletariado' [ . . .] no pueden dejar de combatir" (1).

En Las palabras perdidas, Díaz expone la historia de un grupo de jóvenes escritores: el Flaco, el Gordo, el Rojo y Una, fundadores de la nueva revista literaria $E l$ Güije Ilustrado. Díaz revela el acontecer en las vidas de éstos y muchos otros jóvenes artistas que, por razones diversas, pierden el poder de la creación a causa de las pautas impuestas por el nuevo proyecto revolucionario. Díaz explora una problemática que James Buckwalter-Arias define como "the confrontation between the artist and the government official" y agrega que el texto "makes a case, implicitly or explicitly, for an alternative cultural politics" (365). Buckwalter-Arias considera además que Las palabras perdidas es uno de los textos de la narrativa cubana que reta abiertamente la política represiva del régimen: "The most explicit, strident critique [. . .] is leveled at the regime. This critique, framed by the encounter between the artist and the government official, can be thought of as a restaging of the most memorable [. . . ] dialogues between intellectuals 
and government officials that took place in the 1960s and 1970s" (365). El conflicto entre el artista y el burócrata y el triunfo de éste último sobre su adversario se resume en la interminable y agónica entrevista del Flaco, líder de los fundadores de la revista, con el Compañero Director, donde se indica la validez de la afirmación de que "el arte revolucionario según la estética del realismo socialista impuesta desde los años 60 en la isla, anulaba cualquier espacio de duda o ambigüedad en la representación artística exigiendo del artista una transparencia ideológica acorde con los presupuestos revolucionarios" (Camacho 1). Y la ausencia de esa transparencia ideológica de los Güijes es, en efecto, la causante del fracaso de ese proyecto literario.

Entre los problemas que encuentra el Compañero Director al revisar el material que está por publicarse están los desnudos de Julio Antonio Mella y Tina Modotti, destinados a la portada y contraportada de la revista ${ }^{8}$. A esto se une el hecho de que el Flaco ha seleccionado para la publicación un artículo escrito por un recluta de las Unidades Militares de Ayuda a la Producción (UMAP), en el que el autor propone humanizar la Plaza de la Revolución convirtiéndola en un paseo, una plaza que, según el director, ya está más que humanizada por los miles de cubanos que asisten a los actos revolucionarios. Casi todo el material que han preparado los Güijes pertenece a la categoría de no publicable porque carece de la transparencia política ya mencionada. El Compañero Director tiene preparado un argumento para justificar la censura de cada uno de los proyectos. Por ejemplo, al referirse al poema del Gordo "Réquiem" pregunta: “¿Cómo justificar la publicación de unos versos donde se dice que La Habana está

\footnotetext{
${ }^{8}$ Los desnudos de Julio Antonio Mella y Tina Modotti son inaceptables para el director del periódico ya que constituyen una desacralización de ambas figuras, estandartes del partido comunista, sobre todo Mella, fundador de dicho partido en Cuba.
} 
muerta?” (321). Y al recibir la respuesta del Flaco de que sólo se trata de una metáfora, responde: "Equivocada, a mi modo de ver [ . . . . No se puede, hoy por hoy, escribir sobre La Habana sin tener en cuenta lo que la revolución ha hecho por ella" (321). También son inaceptables el cuento del Flaco donde presuntamente se burla de Marx y Lenin y el hecho de que la diseñadora de la revista, Una, haya sido expulsada de la Universidad de Lomonósov.

Frente a todos los obstáculos que presenta el director, el sentir del Flaco, el artista, coincide curiosamente con el del escritor Jorge Alberto Aguiar Díaz, quien afirma, al finalizar una lectura de poesía con un grupo de jóvenes en La Habana: "El rostro de un organizador y funcionario del centro [ . . . ] fue suficiente para comprender que mi lectura molestaba a la oficialidad. Para mí no fue necesaria otra advertencia para saber que nunca se podría articular libremente un proyecto de jóvenes artistas al margen de la cultura oficial" (3). En la entrevista entre el director y el Flaco se sella el destino de los Güijes. El futuro de todos está en manos del director del periódico y de cierta forma en manos del Flaco, como representante del grupo. Es el Flaco quien rechaza la propuesta del director de trabajar en otra publicación siguiendo estrictamente sus directivas. Es él quien decide silenciar a los Güijes, antes de prostituirlos. Y a pesar de los reproches que recibe de sus compañeros, está convencido de que ellos nunca podrían trabajar en la mediocridad de la literatura propagandista que le propone el director del periódico. La disyuntiva de callar o escribir se convierte entonces en una obsesión para el Flaco. Muchos años después de las 
sanciones, el Flaco sigue debatiéndose entre callar y escribir, algo que ocurre con frecuencia en los sistemas donde impera la censura?

Una de las figuras claves en el texto de Jesús Díaz es José Lezama Lima. Es curioso notar que Díaz, a raíz de la publicación de Paradiso, declara: "A muchos nos ha preocupado la publicación de Paradiso y la influencia que dicha novela pueda ejercer sobre la juventud. Esta preocupación, si se encuentra fundamentada, si es racional, es justa" (Para una cultura 621). Treinta y cuatro años después su novela Las palabras perdidas es, entre otras cosas, un homenaje sui generis a José Lezama Lima, el "Poeta Inmenso", y a otros escritores como Alejo Carpentier, Virgilio Piñera, Eliseo Diego y Nicolás Guillén. El homenaje consiste en la entrega oral de un epitafio a cada uno de estos escritores: "Lo asesinamos porque usted es demasiado grande [. . .]. Como todo muerto que se respete, Maestro, usted debe tener un epitafio, y nosotros, los jóvenes poetas del Güije Ilustrado se lo hemos escrito" $(132)^{10}$. La cita anterior propone un cuestionamiento a la tesis de Rafael Rojas de que Las palabras perdidas es "una novela que [. . . ] rendía homenaje a la gran literatura de la isla (Guillén, Carpentier, Lezama, Diego, Piñera), la cual era invocada, casi como una tabla de salvación nacional frente a la mezquindad de la política” (320). No obstante, cabe preguntarse: ¿Cuánto de genuina admiración hay en ese susodicho homenaje, y cuánto de burla? El lector queda con la

\footnotetext{
${ }^{9}$ Mónica Olivares discute este tipo de actitud tan común entre los escritores españoles durante la dictadura de Franco, y afirma lo siguiente: "The most striking censorship of Spanish literary culture was not that of the dictatorial system nor that of the publishing houses; it arose from the inner nature of the writers themselves. In the very process of writing, authors felt inhibited, and so silenced their inner voices because they were reluctant to alter their works and decided not to publish until Franco's term of office expired" (112).

${ }^{10}$ El autor del epitafio a Lezama es El Flaco, pero es El Gordo quien asume la autoría de los versos durante una entrevista con el poeta: "Jamás viajó ni a Nueva York ni a Roma, / José Lezama Lima, vida vana, / entre nosotros, en su vieja Habana, se dedicó a escribir, mató el idioma" (133).
} 
tarea de descifrar el significado de los epitafios que los Güijes crean para ellas ${ }^{11}$. En fin, la posición de Jesús Díaz frente a los autores en cuestión es bastante crítica porque los epitafios, lejos de contener alabanzas, sólo se mofan de los moribundos escritores. Y ésa es otra interrogante que queda sin respuesta: ¿Por qué deben morir los grandes? ¿Tendrá esa postura algo que ver con el proyecto revolucionario de eliminar los "lastres" del pasado?

Si bien es cierto que cada lector debe crear su propia teoría acerca de lo que constituye el mensaje del texto, sí queda claro que Las palabras perdidas es un ataque a la censura literaria impuesta por el gobierno, una fuerte crítica a la literatura comprometida y una defensa del poeta que merece hacer uso de su libertad intelectual sin tener que someterse a las pautas de una cultura oficial. Esto sin embargo es bastante curioso, si se tiene en cuenta la postura anterior de Díaz frente a la posible influencia negativa de Paradiso en la juventud revolucionaria cubana. Poco después de estas declaraciones tiene lugar para Díaz lo que Rojas define como "el primer tropiezo de Díaz bajo el régimen castrista" cuando, como director de El Caimán Barbudo, permite la publicación del artículo de Heberto Padilla en el que alaba la novela Tres tristes tigres de

\footnotetext{
"Epitafio a Carpentier, cuestionando su identidad cubana: "Vuelve a París la próxima semana" (203). Epitafio a Piñera, burlándose del carácter trágico de su obra: "Yace Virgilio bajo esta losa fría; / ya no podrá contarnos sus dolores, / sus teatrales delirios y agonías. / (Por fin descansan él y sus lectores)" (212). Epitafio a Eliseo Diego, haciendo burla del olvido en que ha caído su primera colección de relatos En las oscuras manos del olvido (1942): "Caminante, aquí yace tendido / Eliseo Diego, el escritor. / Lo mató a cabillazos un lector / de En las oscuras manos del olvido" (221). Epitafio a Nicolás Guillén, mofándose de su poema "Tengo" (1964) y denunciando los méritos que le ha ganado su poesía propagandista: "Tuvo, vamos a ver / mucho más de lo que tenía que tener" (255).
} 
Guillermo Cabrera Infante. Como castigo por haber autorizado la publicación del artículo, Díaz es cesado como director de la revista $(312)^{12}$.

Los vaivenes intelectuales e ideológicos de Jesús Díaz y las represalias de las que es víctima a través de su carrera y de su vida quedan plasmados en esta novela, por lo que cabe definir el texto como una especie de testimonio. Con esta noción coincide Buckwalter-Arias cuando dice que Las palabras perdidas presenta "the Cuban government's represión of a group of writers who try to publish a literary magazine" $y$ que "the novel itself is the fruit of that effort: including poems, stories, and essays given by its characters, it is in a sense the literary magazine the young writers had tried to publish in Cuba" $(367)^{13}$. Pero el carácter testimonial del texto es complejo y multidimensional. Por una parte está la actitud de los Güijes frente a las grandes figuras de la literatura cubana, en especial Lezama Lima. Por otra, está la postura represiva que adoptan estos jóvenes poetas, cuando se encuentran en una relativa situación de poder, ya que como editores de la revista son ellos quienes deciden (o al menos eso creen) lo que ha de publicarse y lo que ha de ser rechazado. Y por último está el ostracismo y el silenciamiento de los que ellos mismos son objeto por haber irrespetado las pautas establecidas.

Al comienzo de la trama, los escritores se presentan como "una nueva generación de escritores [que] había surgido con la revolución [. . .] jóvenes que no tenían

\footnotetext{
${ }^{12}$ Éste, aunque el primero, no es el único tropiezo de Jesús Díaz con el gobierno. Su labor en la revista Pensamiento Crítico provoca fuertes represalias por parte del gobierno, específicamente el artículo "El marxismo de Lenin. Del X Congreso a la muerte (1921-1924)". La publicación de este artículo provoca la clausura de Pensamiento Crítico y la acusación de "diversionismo ideológico a sus editores (Rojas 314-15).

${ }^{13}$ Buckwalter-Arias agrega a este respecto que el hecho de que la novela de Díaz haya llegado a publicarse representa el triunfo de la literatura sobre la política cultural del régimen, y que el texto, además de ser una crónica de la represión es una prueba tangible de la derrota que sufre el burócrata frente al artista (317).
} 
compromisos con el pasado. [Si] el pecado original de los intelectuales cubanos era el no ser auténticamente revolucionarios, [. . .] los jóvenes hijos de la revolución sí lo eran (7071). Sin embargo, el desarrollo del texto presenta a cuatro jóvenes intelectuales que, como explica Rojas, "rozan el distanciamiento moral del artista bajo el comunismo, justo cuando sienten que las demandas del poder imponen la renuncia a la búsqueda de una expresión en la alta literatura" (321). Por tanto, como ha de verse en el transcurso de la trama, mucho distará el destino de estos hombres y mujeres de aquellos ideales que, en su juventud, parecían tan claramente delineados.

Cabe notar, sin embargo, que Jesús Díaz no presenta el concepto de la derrota y la decadencia del hombre que nunca llegó a ser Nuevo desde una óptica maniqueísta, pues no muestra al artista como una simple víctima del sistema. Al contrario, todos los personajes que representan al artista de la era revolucionaria —el Gordo, el Flaco, el Rojo y Una - también son victimarios. Como líderes del grupo de escritores y poetas que pretende fundar el Güije Ilustrado, tratan inútilmente de desafiar a la censura, de ejercer su derecho a la libre expresión y de cumplir con su misión de poetas sin compromiso político-social. Pero muy a pesar de esa misión, también desempeñan la función de censores hacia sus colegas, adoptando una actitud exclusivista y despótica. El Rojo es quien mantiene más firmemente la conducta exclusivista. Ve en los demás poetas, en aquellos que representan al joven poeta revolucionario, una mediocridad inaceptable. Por eso le molestan los epitafios que han escrito sus compañeros, ya que, a su modo de ver, pecan de vulgares y mediocres, sobre todo por tratarse de epitafios para tan importantes figuras literarias. Su aborrecimiento por la mediocridad se hace evidente en todo el texto. Por ejemplo, cuando el Flaco le menciona la posibilidad de fundar una nueva revista 
literaria, El Rojo piensa (pero no dice) que lo entusiasma la idea de una publicación "donde al fin podría limpiar de mediocres, a trallazo limpio, los establos de la literatura" (47). Sin embargo, también es consciente de que los obstáculos "hacían virtualmente irrealizable el proyecto" (47).

Este grupo de poetas enfrenta una seria paradoja, pues se encuentra atrapado entre la censura gubernamental y su propia labor represiva. Cuando el artículo de uno de los aspirantes es rechazado sin miramientos por la revista oficial de la Federación de Estudiantes, ellos consideran que publicar el artículo sería un suicidio. Por lo tanto tienen que cumplir con su función de censores para evitar futuros obstáculos en la publicación de la revista: "No queriendo aparecer como censores ante el Mulo, se acogieron al hecho cierto de que el texto era demasiado largo [. . .] y que sería imposible reproducir la belleza de los dibujos" (172). Pero cuando el Flaco decide que sí ha de publicarse el artículo en $E l$ Güije, el Rojo se opone enérgicamente: "El Rojo había reaccionado contra esa decisión que ponía al desnudo su condición de censor y amenazaba la existencia misma del suplemento, desde donde pensaba ejercer por fin la justicia poética" (173).

Por otro lado, Una, la única mujer en este patriarcal grupo de editores es a la vez una de sus víctimas, ya que el grupo ha objetado repetidamente a la publicación de su poema si éste no es sometido a correcciones. La ambivalencia de Una radica en que aunque les ha dado un ultimátum a sus colegas de publicar la versión original del poema o no ha de publicarse, pero "inmediatamente se [siente] desfallecer, aterrada ante la posibilidad de que la excluyeran" (200). Y aunque el Flaco ha aceptado sus condiciones, Una se encuentra vagando de cola en cola por la ciudad, buscando cualquier cosa para ofrecerles una cena al Gordo, al Flaco y al Rojo. Llega incluso a pensar "que no le 
saldrían tan mal las cosas si les freía íntegra su cuota de pollo y simulaba no tener hambre. En realidad les debía más que eso" (201). En cierto sentido, Una representa el artista que se prostituye para no ser silenciado.

Los hechos que ocurren en las vidas de los Güijes representan una noción de índole un tanto kármica. La idea de que el hombre ha de cosechar lo que siembre se expresa sutilmente en una conversación entre el Flaco y el Rubito, uno de los poetas excluidos de la publicación del Güije por su mediocridad literaria. Muchos años después de la fallida publicación del Güije Ilustrado, el Rubito se encuentra en Rusia desempañando funciones diplomáticas, y el futuro del Flaco depende precisamente de él. Con el paso de los años, aún se hace evidente el resentimiento del Rubito: "En todo caso yo me pasaba la vida detrás de ustedes tratando de... de ser un Güije [. . .]. Aprendí sus costumbres incluso, no tuve más remedio [ . . .]. Lo que ayer estaba arriba [ . . . ] hoy está abajo. Es el destino, Flaco; tú mejor que nadie deberías saberlo" (191-192). Y regodeándose en el resentimiento que no logra disimular, el Rubito, a lo largo de una suntuosa cena en la que hace alarde de todo su poder adquisitivo, se convierte en un constante recordatorio de que el efímero poder que en el pasado tuvieron los Güijes y que de tan poco les sirvió, hoy lo tiene él.

La sentencia del Rubito representa, empero, una versión muy particular del concepto del karma. En primer lugar, si la ley del karma es una ley universal de Causa y Efecto, entonces el trágico final de los Güijes (muerte, ostracismo, demencia, destierro) debería ser el resultado directo de las acciones pasadas de estos individuos. Sin embargo, es curioso que la ley del Karma que se entrevé durante la larga velada del Rubito y el Flaco en la Torre Ostánkino se convierte en una suerte de apología de la venganza. O sea 
que, si se sitúan sobre la balanza las acciones de los Güijes (causa) con el desenlace que sufren sus vidas (efecto), no existe la correlación que ha de esperarse en una ley de compensación ${ }^{14}$. El Rubito es, entonces, portavoz de una ley de venganza y no de retribución, lo cual hace que el texto se convierta en una denuncia al modus operandi del aparato represivo. Díaz utiliza el éxito del Rubito y la derrota de los antiguos Güijes como una suerte de radiografía del aparato político cubano del que una vez formó parte y del que luego fue víctima.

El Flaco, por su parte, es una suerte de alma artística en pena. En él sólo quedan los despojos del creador. Porque aunque Rojas afirme que la publicación de Las palabras perdidas indica el triunfo del intelectual frente al burócrata, lo cierto es que a nivel de texto, el Flaco no logra tomar una decisión entre callar o escribir (causa) porque sabe que ambas opciones tendrían consecuencias negativas (efecto). Al final, el lector queda con una imagen desesperanzada del poeta, imagen que coincide con la que da Aguiar Díaz cuando describe la actitud de un grupo de jóvenes artistas que se encuentran al margen de la cultura oficial: "Muchos de aquellos jóvenes han perdido el entusiasmo. Veo en sus ojos, en sus gestos, y comprendo por lo que comentan, que la pasión comienza a enajenarlos" (1). En retrospectiva, el destino de los Güijes es similar al que ellos tratan de imponer a las grandes figuras literarias, sólo que a ellos nadie les escribe epitafio alguno. Lo que tienen en común los grandes con los Güijes es simplemente su condición de

\footnotetext{
14 Según propone la ley del karma, la simple censura del material preparado para la publicación de la revista literaria habría establecido la compensación por la censura que los jóvenes escritores aplican a sus colegas. Sin embargo, son víctimas de mucho más. Todos son acusados de diversionismo ideológico. El Rojo muere de cáncer, Una se suicida, El Gordo y el Flaco son expulsados de la universidad y enviados a trabajar en la agricultura. Luego de varios años en el campo, el Gordo desaparece y el Flaco sufre de demencia y pasa un largo tiempo en un hospital psiquiátrico.
} 
artistas, cuyo reconocimiento depende de la política cultural del sistema, como afirma Fernando Rodríguez Genovés:

El escritor, el artista, así como el antiguo bufón de corte o trovador de feria, ha debido soportar y todavía soporta en la actualidad un ambiguo y en ocasiones ambivalente estatus: dependiendo del humor cambiante y del ánimo caprichoso o soliviantado del poder, conoce la gloria del éxito, los parabienes de la fortuna y las lisonjas más honorables, o cae sin remisión en el mayor de los denuestos, las burlas más hirientes o en el desgraciado despecho del olvido. Se les pide mucho y se les da en correspondencia... hasta que cansan, molestan o aburren $\mathrm{y}$, entonces, se acabaron los privilegios y comienza el ostracismo (para siempre, o en espera de aires más favorables). (96)

En Las palabras perdidas el artista se define a través de su circunstancia, idea que confirma Armando Valdés al referirse al intelectual "atrapado por el azar de la Historia" (2). Y precisamente porque ese intelectual es él (Jesús Díaz), encarnado en el Gordo, el Flaco, el Rojo y Una, e incluso en el Rubito, la obra tiene un claro carácter autobiográfico que, como afirma Valdés, le otorga a la obra madurez y permanencia (2). Cabe agregar que la madurez y la permanencia del texto se deben también al carácter universal del conflicto que presenta Díaz y que coincide con la realidad de todo intelectual y de todo artista que se encuentre atrapado, por azar o no, en un entorno como el que aquí se examina.

El entorno constituye el denominador común entre los Güijes y otro grupo de jóvenes amigos muy diferente que presenta Abel Prieto en El vuelo del Gato: la Piña del 
Pre de Marianao. Prieto presenta el acontecer en la vida de estos amigos que son la esencia del "gato volante"15. A su vez, estos hombres son la materialización del desencanto y el desarraigo que forman parte de la idiosincrasia del cubano de hoy en día. La voz narrativa, a través de la metáfora del juego de dominó, presenta una poderosa imagen de la decadencia del cubano:

Sólo me acompañan los dioses báquicos del dominó, desordenados y soeces. Sigo practicando el dominó a la cubana, aunque con menos gusto y destreza que en mi juventud: el ron, hoy por hoy, no sazona el juego como un ingrediente pícaro; ahora (desde la Punta de Maisí al Cabo de San Antonio) el ron se ha instalado como un tirano sobre el dominó a la cubana y embrutece a los sapos y a los jugadores activos y va matando por exceso lo mejor del juego (24).

Tanto el cuarteto de Las palabras perdidas como el de El vuelo del gato revelan el destino del utópico proyecto de la creación de un Hombre Nuevo. Todos ellos son muestra de que los moldes sociales impuestos se desmoronan inevitablemente, y que de hecho casi nunca llegan a adquirir forma. Ambos textos ratifican el argumento de Armando Ribas de que "la denominada filosofía socialista parte de la pretensión de construir una sociedad con hombres que no existen, sino que hay que crearlos" (162). El pensamiento crítico en El vuelo del gato se produce a través de una suerte de estudio etnográfico que apunta principalmente hacia el cubano como ente socio-cultural, y no

\footnotetext{
${ }^{15}$ El concepto viene del poema "Universalidad del roce" de Lezama Lima. En un fragmento del poema se expresa que "El gato copulando con la marta / no parece un gato / de piel shakesperiana y estrellada, / ni una marta de ojos fosforescentes. / Engendran el gato volante". Este engendro del gato volante, según el propio autor, parece ser la definición por excelencia de la idiosincrasia cubana que a su vez constituye la causa del fracaso del proyecto revolucionario.
} 
hacia las figuras del liderazgo revolucionario en sí. A simple vista, el texto de Prieto es un análisis que el propio autor define como "la búsqueda de lo particular, de las esencias de lo cubano, y no de una manera metafísica, sino como algo complejo que se renueva" (Tabares 2). Pero de dicho bosquejo etnológico se desprende que la idiosincrasia del cubano y su naturaleza demasiado exótica y compleja han trazado por sí solas el destino del pueblo de la isla, ya que la cultura que Prieto define como "gato volante" carece de la madurez y de la profundidad intelectuales y filosóficas necesarias para forjar un futuro bajo las pautas propuestas en el proyecto revolucionario. Si bien la crítica directa al sistema de gobierno establecido con el triunfo de la revolución va dirigida fundamentalmente a la década del sesenta, no deja de estar presente el análisis de la realidad cubana de los noventa, que expone el carácter utópico e irrealizable de la propuesta socialista en Cuba.

En una mirada retrospectiva, el narrador reflexiona sobre el tema del diversionismo ideológico a través de la reivindicación de la figura de Lezama Lima. El primer ejemplo de esa reivindicación es el título mismo de la novela, un abierto homenaje al poeta, figura que a través de los años ha sido motivo de una abundante controversia en cuanto a la postura del gobierno cubano frente a su obra. La polémica que rodea la obra de Lezama Lima durante las dos primeras décadas de la revolución es un factor fundamental en el texto de Prieto, pues según el propio autor, el poeta es la clave de esta novela: "Su obra plantea desafíos permanentes para el lector. Siempre lo está sorprendiendo. Es el antídoto contra todo dogma, esquema y rigidez. Él me dio la clave de mi última novela publicada [. . .]. En mi literatura está presente esa búsqueda de Lezama, de lo particular, de las esencias de lo cubano" (Tabares 2). El papel inspirador 
que la obra y la filosofía lezamianas desempeñan en el texto de Prieto presentan de antemano un elemento subversivo que, aunque cuestionable y de hecho cuestionado, refleja el reto del artista a su entorno. La posición del gobierno cubano frente a la obra de Lezama y frente al poeta como tal ha sido motivo una controversia que si algo ha sabido indicar es la urgencia del cuestionamiento.

Por una parte, hay quienes aseguran que Lezama nunca fue censurado ni silenciado por las autoridades culturales de la isla, y que la censura y silenciamiento que se le impusieron al poeta no fueron obra del gobierno. Por ejemplo, Amauri Francisco Gutiérrez, en respuesta al libro de Antonio José Ponte El libro perdido de los origenistas, declara que "las causas de esa censura y de ese olvido son varias. Hay mil testimonios sobre el apoyo generalizado a la norma estética y disciplinar concretada en política por el Congreso en el cual hubo muchísimos participantes ${ }^{16}$. La responsabilidad de esa política cultural no hay que atribuirla sólo al Ministro de Cultura y otros ministerios, tal y como dice Ponte" (2). La declaración de Gutiérrez coincide de cierto modo con la apología del gobierno cubano que se hace evidente en El vuelo del gato. Incluso declara que "buena parte de la responsabilidad la tienen todos aquellos que apoyaron normas estéticas y disciplinares equivocadas [y que] atribuir responsabilidad al sistema ofrece también el facilismo de no ver responsabilidades en las individualidades involucradas" (2). Por su parte, Ponte, cuyo enfoque es principalmente la rehabilitación de la obra de Lezama y de otros intelectuales del grupo Orígenes, señala que tal rehabilitación se debió a un plan

\footnotetext{
${ }^{16}$ Gutiérrez se refiere a la Declaración del Primer Congreso Nacional de Educación y Cultura, en la que el homosexualismo queda prohibido por la política cultural del gobierno. La gaceta de Cuba dedica esta nota a la declaración: "En el tratamiento del homosexualismo la Comisión llegó a la conclusión de que no es permisible que por medio de la calidad artística reconocidos homosexuales ganen influencia que incida en la formación de nuestra juventud" (10).
} 
oficial y que fue orquestada desde el gobierno y las esferas del poder en Cuba. Ese argumento de Ponte, tal vez podría explicar por qué Abel Prieto intenta restablecer con tanta vehemencia la gloria de Lezama.

Empero, cabe la posibilidad de que el homenaje que se le rinde a Lezama en el texto de Prieto no tenga relación alguna con la rehabilitación gubernamental a la que se refiere Ponte. Quizás Prieto sólo pretenda reivindicar el nombre de grandes figuras que en un período determinado fueron víctimas de la censura, como lo hace con John Lennon, cuya música fue por muchos años símbolo de diversionismo ideológico y de tendencias extranjerizantes. Ese intento representaría por tanto una crítica a la política cultural implantada por el gobierno de la isla. En el caso de Lezama, todo aparece indicar que se trata de una censura moral más que política, provocada por lo que Gutiérrez cataloga del "heterosexismo [que] se hizo política cultural por una Revolución en la cual esta postura moral estaba muy arraigada en la mentalidad común del cubano, [y que] aún hoy lo está un poco" $(4)^{17}$.

A pesar de la evidente crítica a la censura de otrora que vincula en cierto sentido El vuelo del gato con Las palabras perdidas, el verdadero análisis del proyecto revolucionario que hace Prieto está en su definición del cubano de la era revolucionaria. Tal definición gravita hacia dos miembros principales de La Piña del Pre de Marianao: Marco Aurelio y Freddy Mamoncillo. Todo parece indicar que la identidad del cubano se

\footnotetext{
${ }^{17}$ Leonardo Padura parece estar en desacuerdo con la teoría de Gutiérrez y favorecer el punto de vista de Ponte ya que reitera que la censura de la que fue objeto Lezama Lima tiene un carácter innegablemente político: "No estuvo prohibido leer a Lezama. Pero en realidad, sí, porque se hizo una sola edición de su libro capital, Paradiso [.. .] que no pasó de tres mil ejemplares, sin que se haya reeditado sino hasta finales de la década del ochenta[. . . . Además la valoración política de Lezama era bastante equívoca. En los años setenta, finales de la vida de Lezama, se asumía que un escritor debería estar esencial y expresamente comprometido con el proceso revolucionario, no solamente en su trabajo teórico y periodístico, sino incluso en su creación literaria. Y Lezama era incapaz de hacer eso" (Epple 53).
} 
encuentra en algún punto indeterminado entre el estoico Marco Aurelio, cuya frugalidad representa la Vida Verdadera, y el hedonista Freddy Mamoncillo, cuyo utilitarismo es sinónimo de Vida Ficticia ${ }^{18}$. El texto sugiere que tanto Marco Aurelio como Freddy Mamoncillo son muestra del fallido intento de crear un Hombre Nuevo, pero es el lector quien tiene en sus manos la labor de determinar cuál de los dos está más cerca del modelo revolucionario. Al mismo tiempo, el lector debe decidir si los dos están destinados al fracaso, o si acaso en la mezcla de ambos tipos existe una posible materialización del ideal.

El carácter de Marco Aurelio Escobedo se perfila desde el principio de la novela, durante un partido de baloncesto en el que el joven se enfrenta a un temible y corpulento adversario: el Minotauro. El narrador comenta: "Sabíamos que Marco Aurelio era demasiado buena gente, demasiado honesto y puro, e incluso recto, como para lidiar con aquella bestia infame del equipo del Vedado" (12). Es curioso que a pesar de que el narrador utiliza calificativos que definen al buen revolucionario, la palabra "demasiado" transforma esas cualidades en defectos que debilitan el carácter del personaje, y por lo tanto sólo su alianza con un jugador menos escrupuloso (Mamoncillo) permitirá que se efectúe la jugada necesaria para asegurar la victoria de su equipo. El hecho de que este evento se narre al principio de la novela crea en el lector la imagen de derrota que se convierte en una suerte de augurio para el personaje de Marco Aurelio.

El autor se sirve del personaje para criticar varios aspectos del proyecto revolucionario, ya que, además de transformar sus cualidades de Hombre Nuevo en

\footnotetext{
${ }^{18}$ Vida Verdadera y Vida Ficticia, al igual que el contraste entre ambas, son conceptos fundamentales de la filosofia estoica.
} 
defectos, el narrador presenta un elemento de su filosofía de vida que está muy relacionado con unas de las pautas fundamentales de la revolución marxista-leninista: el ateísmo. A partir del triunfo de la revolución, toda práctica religiosa queda al margen de la política revolucionaria, y las imágenes religiosas que antes adornaban los hogares cubanos son remplazadas por las de los héroes de la revolución. Cabe mencionar, incluso, que el reclutamiento a los campos de las UMAP, al igual que la denegación del ingreso a las universidades se debió, en numerosos casos, a la práctica religiosa de los jóvenes (Besada 1). Y a través de la voz narrativa, Abel Prieto se une a la crítica del ateísmo en una referencia que hace sobre Marco Aurelio: "Había heredado aquel ateísmo paterno, desértico, donde no podía crecer vegetación alguna, nada que no estuviera avalado debidamente por la ciencia y la razón" (33) ${ }^{19}$.

Marco Aurelio es una de las realizaciones del "gato volante", engendro incapaz de asumir y ejecutar el plan revolucionario. Por ende, es de esperarse que aparezca en el texto una serie de críticas directas a ciertos sectores de la sociedad con los que Marco Aurelio está involucrado, como por ejemplo la vanguardia ideológica. El narrador, cuyo nombre nunca se llega a revelar a pesar de ser uno de los miembros de la Piña, expresa su temor de que a causa de su arraigada doctrina estoica, y que por pertenecer a la facultad de Derecho y de Ciencias Políticas, Marco Aurelio se deje influenciar por las ideas radicales de la vanguardia ideológica: "Marco Aurelio el nuestro, el Pequeño se podría convertir de ese modo en un extremista de los más peligrosos, en un Torquemada filosóficamente convencido, en un partidario consciente de la línea dura, en el extremista

\footnotetext{
19 "Según Marx expresa en Manuscritos económicos y filosóficos de 1844, "cuando preguntas acerca de la creación de la naturaleza y del hombre haces abstracción del hombre y de la naturaleza. Los postulas como no-existentes y sin embargo quieres que te pruebe que ellos son existentes... el ateísmo es la negación de Dios y postula la existencia del hombre a través de esta negación" (cit. en Florián 42).
} 
orgánico por definición" (60). La cita anterior indica que en el texto hay una critica de las rígidas posturas ideológicas del gobierno cubano a través de todo el proceso revolucionario, y que no se trata precisamente de una crítica a sotto voce. No obstante, el temor parece desvanecerse cuando se le dice al lector que Marco Aurelio ha salido ileso de las influencias dogmáticas de la vanguardia ideológica porque ha podido descubrir en ella a uno de los principales componentes de la sociedad cubana: el oportunista ${ }^{20}$.

Mediante un paralelo entre los miembros de la vanguardia ideológica con los "exhibicionistas estoicos, vividores, parásitos" que sólo pretendían confundir "al vulgo" y trataban de impedir la misión del Emperador, Prieto realiza una amplia apología del líder revolucionario, y presenta a la figura del Jefe de Estado como un incomprendido, como víctima de los que no han sabido entender su misión mesiánica y redentora, culpando a los oportunistas y demagogos del fracaso del proyecto revolucionario (62-63). Achy Obejas coincide con esta interpretación, ya que considera que el texto de Prieto "it contains a long passionate paean to Emperor Marcus Aurelius that can't be read as anything but a defense of Castro" (4). En ese sentido, la aproximación de Prieto en su crítica de las fallas de la revolución coincide también con la postura de Amauri Gutiérrez cuando afirma que "atribuir responsabilidad al sistema ofrece también el facilismo de no ver responsabilidad en las individualidades involucradas" (2).

Freddy Mamoncillo es la representación más fehaciente del individuo cuya actitud frente al proyecto revolucionario provoca el fracaso del mismo, pero desde un ángulo

\footnotetext{
20 "Se le hizo evidente que algunos de los que más gritaban en las llamadas asambleas de radicalización no elaboraban sus discursos desde el núcleo del Alma Razonable [. . .]. Le recordaban cada día más a los exhibicionistas estoicos vividores, parásitos que en la Roma del siglo Il d.n.e. estorbaban la misión pedagógica y esclarecedora de Marco Aurelio el Grande [. . . ] y sembraban la confusión y el caos en el vulgo" (62-63).
} 
opuesto al de Marco Aurelio. Freddy es el oportunista, el que manipula cualquier situación dada hasta tornarla en beneficio personal. A su manera, Freddy vive bajo el lema revolucionario de "Hacer de cada revés una victoria", sólo que en su caso siempre se trata de una victoria personal y no colectiva. Desde muy joven, según recuerda el narrador, este personaje demuestra una tendencia mercantilista que dista mucho de las pautas que ha de seguir un aspirante a Hombre Nuevo. Desde el momento en que es reclutado para el Servicio Militar Obligatorio, Freddy comienza a desarrollar un talento especial para hacerse de una posición de poder. No trata de escapar del servicio militar como hacen muchos mediante el uso de certificados médicos, sino que enfrenta su nueva situación, dispuesto a sacar de ella el mejor partido: "En ese año y pico que pasó en Pinar del Río, Mamoncillo [. . .] desplegó un talento increíble para la compraventa, el trueque, el trapicheo, la importación y la exportación y eso que llaman Acopio de Suministros; acumuló un capital muy considerable en la unidad de medida vigente en la zona (las latas de leche condensada) (51). Ya desde este momento en la trama se vislumbra la tendencia de Mamoncillo a divergir de la conducta propia de un joven revolucionario, conducta que, curiosamente, en la narrativa anterior a este período histórico habría tenido un desenlace negativo para el personaje en cuestión. Pero como ha de verse más adelante, el derrotero que toma la vida de Freddy Mamoncillo es tan impredecible como divergente su comportamiento del ideal del Hombre Nuevo.

Al cumplir el tiempo reglamentario en el Servicio Militar Obligatorio, Mamoncillo pasa a ocupar una plaza de principiante en el Departamento de Relaciones Públicas y Divulgación del Ministerio de Comercio Interior (MINCIN). En el ámbito laboral demuestra el mismo talento que en su período de recluta: su capacidad de 
manipular cualquier situación para alcanzar una posición de poder dentro del entorno en que se encuentre. En el caso de su empleo en el ministerio, Freddy Mamoncillo se las ingenia para desplazar de su cargo al supervisor. Sirviéndose de su incomparable carisma logra ascender rápidamente en la escala laboral. El entorno laboral de Mamoncillo es importante, no sólo porque en él se pone en evidencia el oportunismo de este personaje, sino porque también presenta varios conceptos que contradicen la teoría de la igualdad propuesta por la doctrina de la revolución.

Como ya se ha dicho, Freddy Mamoncillo logra ascender rápidamente en su empresa, algo que se le facilita cuando su antiguo jefe, el viejo Corrales, cae en "baja" o "en desgracia" (81). Es decir, que el alza de Freddy en la empresa depende de que Corrales sea eliminado: "No sabía (infeliz) que se le había posado en la frente una señal fatídica: con su vista de águila desde las altas oficinas encristaladas de los asesores del Ministro el Hombre Influyente reconoció en él la enfermedad y la consideró incurable" (81). La enfermedad a la que se refiere el narrador es la "presencia aparente, el estar y no estar" (80). Corrales se convierte en lo obsoleto, lo inservible, lo inútil, en fin, el fracaso en persona, y por eso cae en desgracia. Cabe agregar que la cita anterior pone de manifiesto, además, toda una noción del poder, y del uso arbitrario del mismo dentro de una sociedad en la que la igualdad social es una suerte de sello publicitario.

Freddy Mamoncillo ha heredado de su madre una filosofía de vida que gravita hacia la noción del adelanto. Por ejemplo, a través de la voz narrativa (ningún personaje de esta novela se expresa directamente) el lector sabe que siendo hijo de blanca con mulato, Freddy vive orgulloso de ser el único de los hijos que ha logrado ocultar su mestizaje. Tanto él como su madre conservan ideas burguesas que aparentemente no 
tienen cabida en la nueva filosofía revolucionaria de la igualdad, y estos rezagos de ideas burguesas constituyen una de las características del gato volante (del cubano) que le impiden llevar a cabo el proyecto revolucionario ${ }^{21}$. Sin embargo, con su filosofía del adelanto, Freddy sí logra realizar sus propios proyectos y satisfacer sus ambiciones personales. Freddy Mamoncillo es esa figura que se mueve dentro del orden socialista para satisfacer sus ambiciones capitalistas, representado así un grave peligro para la revolución. Como afirma Armando Ribas, “[E]l hombre nuevo en un puesto público tiene los mismos intereses como ser humano que los ciudadanos comunes, pero son mucho más improductivos y de hecho más inmorales, pues usan el poder, tal y como lo había previsto el propio Marx en su Crítica a la Filosofia del Estado, en su propio beneficio" (165).

Freddy Mamoncillo es tan capitalista como los cubanos de Miami que tanto critica Prieto en el texto. Son muchas las semejanzas entre Mamoncillo y el tío Manolo de Miami, un pariente de Marco Aurelio. Ambos son la personificación del hedonismo, de la Vida Ficticia, de la búsqueda del placer y la abundancia. El encuentro entre Freddy y Marco Aurelio muestra el innegable contraste entre el estoico desinteresado y libre de toda ambición, que sólo aspira a la virtud y a la Vida Verdadera, y el hedonista que al parecer ha alcanzado la Vida Ficticia que tan feliz lo hace. Luego de obtener su libertad a cambio del apartamento en que vive, para escapar de su mujer, el ahora desamparado

${ }^{21}$ Prieto presenta esos lastres de la antigua clase burguesa frente a la nueva sociedad igualitaria de la revolución. Sin embargo, la postura de la voz narrativa es bastante ambigua y no queda claro si critica el viejo o el nuevo orden social: "[El barrio de Buen Retiro] comenzaba a ser una barriada híbrida [. . .] donde gente pobre y bullanguera ganaba terreno y ocupaba las casas de los que se iban del país, y convivía, chocaba y se mezclaba con 'los históricos de Buen Retiro', es decir, la gente que aspiraba a defender cierto refinamiento y todavía regaba sus jardines y evitaba acercarse a las mesas de dominó y a los grupos de muchachones groseros y a los perros satos" (24). 
Marco Aurelio abandona el hogar con unas pocas pertenencias en un cajón y su bicicleta. Pero sentado en el banco de un parque habanero, el estoico corre con la suerte de encontrarse casualmente con un Freddy Mamoncillo que en nada difiere de sus robustos parientes del exilio. Mamoncillo ya no es el joven delgado de antes, sino que con varios kilos de más es la viva estampa del buen comer. Al encontrarse con su antiguo amigo, Mamoncillo experimenta una gran alegría frente a la oportunidad de exhibir su automóvil y su teléfono celular, placer que sólo es superado por la oportunidad de ofrecerle a Marco Aurelio albergue en su casa donde hay "de todo" (153). El carisma de Freddy Mamoncillo, visto a través de la voz narrativa, le impide al lector determinar si su actitud de buen samaritano es honesta o si responde a la condescendencia característica de los que tienen más. Freddy Mamoncillo, hombre de éxito, bien alimentado, con auto, teléfono, viajes al extranjero y una casa donde abundan la comida, la bebida y muchos amigos con quienes compartir todo aquello, sólo necesita la satisfacción personal que le produce la filantropía.

El rencuentro fortuito entre los dos amigos es la vía que utiliza el autor para, a través del contraste, expresar el mensaje subyacente del texto en cuanto al insuperable poder del dinero y el triunfo del capitalismo cubano. No obstante, como ha de verse, Prieto sugiere que tal vez se trate sólo de un triunfo superficial y efímero ya que Mamoncillo se convierte rápidamente en víctima de la traición de su protegido y su mujer cuando comienza la relación adúltera entre Marco Aurelio y Amarilis. El comienzo de esta relación le otorga validez al comentario de Achy Obejas de que "El vuelo del gato [is] aware of the inherent conflict between tropical sensuality and the ethics of stoicism 
required by socialism and other ways of thinking that reject materialism and sentimentalism" (3).

Al principio parece que Marco Aurelio es presa de su debilidad al dejarse seducir por la mujer de su amigo muy a su pesar. Pero muy pronto Marco Aurelio abandona el camino en busca de la virtud y se entrega de lleno a la búsqueda del placer, mientras Freddy Mamoncillo viaja por Europa en asuntos de negocios, preocupado solamente por llenar la maleta con regalos y baratijas para sus amigos y parientes. El comportamiento de Marco Aurelio explica una sentencia de la voz narrativa a principio del texto: "Marco Aurelio (el pequeño) el que nunca llegaría a ser ni grande, ni emperador, ni filósofo" (60). En ese sentido, Marco Aurelio es un personaje que ilustra la afirmación de Ribas de que "el desinterés está muy lejos de representar la virtud por oposición al pecado del interés [y que aunque] es un derecho del hombre la estoicidad, en modo alguno es esa conducta el paradigma de la virtud" $(55,132)$.

Si bien es cierto que Freddy Mamoncillo representa la consabida Vida Ficticia cuyo eje central es el bienestar económico, Marco Aurelio, a pesar de su desapego de lo material y de su frugalidad tampoco representa la virtud, y por eso no ha de alcanzar la Vida Verdadera. La teoría de Ribas, asimismo, representa una apología del capitalista, que beneficia directamente al personaje de Freddy Mamoncillo: "También es cierto que el interés en muchos casos se dirige a cosas materiales, pero no es menos cierto que la creación de riqueza a partir del egoísmo [no del altruismo] no es contraria al interés general como pretende el socialismo" (56). En cierto sentido podría decirse que si Freddy Mamoncillo posee una virtud es que sus acciones y su vida se rigen por una filosofía de vida que asume plenamente, sin renegar de ella. Si bien este personaje es la viva imagen 
del oportunista, al menos es honesto consigo mismo y con los que le rodean, y por eso triunfa en la única manera que parece interesarle: económicamente.

Vale preguntarse entonces hasta qué punto Marco Aurelio es un legítimo estoico. Es muy probable que el estoicismo de Marco Aurelio no sea más que el resultado de una doctrina impuesta por su padre, Serafín Escobedo, y que luego él mismo trata de adoptar sin creer en ella lo suficiente como para acatar sus dictámenes con la convicción necesaria. Marco Aurelio no alcanza la tan anhelada virtud porque no logra controlar sus pasiones, fundamento del estoicismo ${ }^{22}$. Tal vez alcanzar la ataraxia sea un imposible, si para él el estoicismo no es más que una filosofía que insiste en adoptar, y no una creencia legítima. Si ese es el caso, lo cual el texto parece indicar, entonces Marco Aurelio está condenado a la infructuosa búsqueda de la Vida Verdadera y de la virtud. En cierto sentido, la incapacidad de Marco Aurelio para poner en práctica el estoicismo como filosofía de vida representa la incapacidad del cubano para asumir y poner en práctica el proyecto revolucionario.

Del mismo modo cabe afirmar que si bien Freddy Mamoncillo y Marco Aurelio representan polos diametralmente opuestos en cuanto a sus respectivas visiones de la moral y la ética, ninguno de los dos representa la virtud como tal, ni el estoico ni el hedonista. En ese sentido se puede afirmar que Prieto se aparta de una visión puramente maniquea en la que el estoico, sacrificado por un ideal determinado representaría al

\footnotetext{
22 "El bien moral y la virtud consisten [. . .] en vivir de acuerdo con la razón, evitando las pasiones (pathos) que no son sino desviaciones de nuestra propia naturaleza racional. El placer, el dolor, el temor pueden dominarse a través del autocontrol ejercitado por la razón, la impasibilidad (apátheia) y la imperturbabilidad (ataraxía). Estas surgirán de la comprensión de que no hay ni bien ni mal en sí ya que todo lo que ocurre es parte de un proyecto cósmico. Sólo los ignorantes que desconocen el lógos universal se dejan arrastrar por sus pasiones. El ideal de sabio es aquel que vive conforme a la razón, está libre de pasiones" (Diez de la Cortina 2).
} 
héroe, al Hombre Nuevo, mientras que el hedonista representaría al mercantilista, al antihéroe. Pero, por el contrario, como bien se observa en este texto, ambos personajes, por razones diferentes, divergen del ideal del Hombre Nuevo, y ambos carecen de todo espíritu de sacrificio, de toda heroicidad y de todo sentir revolucionario. Ellos, cada cual a su modo, representan lo que Edward González define como "a politically disengaged society", que según él constituye uno de los legados del fidelismo y el totalitarismo en Cuba $(38)^{23}$. El legado que describe González propone una innegable contradicción pues el requisito fundamental para un aspirante a Hombre Nuevo es el compromiso total e incondicional con la revolución, algo que, como indica González, no ha sido el caso en Cuba.

La interrogante que Prieto deja en manos del lector gira en torno al nacimiento del hijo de Amarilis. Freddy Mamoncillo y Marco Aurelio esperan frente al hospital el nacimiento de la criatura, y en esta espera se instala la duda, al menos para Marco Aurelio, porque todo parece indicar que Mamoncillo no está al tanto del adulterio del que ha sido víctima. Al final de la novela, Prieto sume al lector en la agónica espera del nacimiento, de saber si el hijo de Amarilis es un engendro del estoico o del hedonista. La espera de los dos hombres frente al hospital constituye una poderosa metáfora, ya que en ella se sintetiza la expectativa de lo que ha de surgir del Hombre Nuevo que nunca llegó a serlo. El hijo, ya sea de Marco Aurelio o de Freddy Mamoncillo, representa el futuro. La imagen de Marco Aurelio y Mamoncillo sentados frente al Hospital Materno "como dos

\footnotetext{
23 "After experiencing decades of political exhortations, mass mobilizations, and personal sacrifices that were premised on creating a better socialist future for themselves and their children, [ . .]. Cubans are too consumed with their daily struggles for survival - sobrevivir - and too disillusioned with politics to engage in political action. Rather than rebel, which is a consumate political act, many may have become disengaged from politics" (González 38).
} 
animalitos expectantes, como dos peces que aletean, hechizados, nerviosos, indefensos" (316), no es más que una metáfora de la duda del cubano frente al porvenir luego que su fracaso como Hombre Nuevo se ha hecho evidente.

La incertidumbre es un elemento común entre Las palabras perdidas y El vuelo del gato. Por una parte, la crítica de la política cultural revolucionaria y la actitud del artista frente a ella crea una interrogante que sólo el lector puede resolver: ¿Escribir o callar? Al mismo tiempo, es el lector quien queda con la interrogante de cuál es el futuro de ese engendro que nunca llegó a ser Hombre Nuevo. Lo más importante, sin embargo, es que tanto Díaz como Prieto dejan la respuesta en manos del lector. Es evidente, sin embargo, que ambos presentan el proceso de decadencia y degradación por el que atraviesan los hombres y mujeres que en un momento determinado de la historia de la revolución fueron los candidatos a Hombres Nuevos. Ésta sería la arcilla a la que se refería Ernesto Guevara al hablar de una juventud moldeable y fácilmente transformable en el hombre del futuro, pero con los años se sabe que, lejos de alcanzar dicho ideal, se apartan vertiginosamente de él, tomando rumbo hacia el desencanto que implica toda misión fracasada.

Jesús Díaz, Abel Prieto y Leonardo Padura poseen diferentes estilos y contrastantes aproximaciones en cuanto al cuestionamiento se refiere. Empero, estos autores tienen algo en común, y es la necesidad que crean en el lector de cuestionar su realidad y de mirarla fría y desapasionadamente, como sólo lo pueden hacer quienes tienen a su favor años de experiencias y un sinnúmero de errores acumulado. Nótese que los personajes principales de los tres textos son hombres maduros que, si bien, vivieron los comienzos de la era revolucionaria con las ilusiones y el entusiasmo característicos de 
la juventud, han llegado a una etapa en sus vidas en que además de cuestionarse lo que les rodea, evalúan rigurosamente el devenir de sus propias vidas. Todos parecen llegar a la conclusión de que han involucionado en lugar de evolucionar con el proyecto de la revolución. La presencia del pensamiento crítico en los tres textos cobra valor al llegar a manos del lector, quien probablemente no podrá hacer caso omiso a la duda y a la incertidumbre que agobian a los personajes. Trátese de la historia oficial, de la censura literaria o de los efectos nocivos de la revolución en el cubano y viceversa, lo fundamental es que el cuestionamiento, que hasta el momento no formaba parte de la narrativa cubana comienza a ser un elemento fundamental en el Periodo Especial. Y si además de urgir al cuestionamiento, el escritor le ofrece al lector la libertad de arribar a sus propias conclusiones, entonces está claro que se ha producido, por medio de un legítimo acto de rebeldía, una verdadera revolución literaria. 


\section{Conclusiones}

El análisis que aquí se ha realizado sobre la narrativa cubana del Periodo Especial en Tiempos de Paz produce una serie de conclusiones que demuestran la estrecha relación que existe entre la creación literaria y el entorno social en que ésta se desarrolla. Cabe concluir que el contraste que se observa entre la narrativa que surge con el Periodo Especial y la de las décadas que le preceden dentro de la era revolucionaria existe debido a los cambios en la postura gubernamental frente a la intelectualidad y las artes cubanas, y también a los cambios socio-económicos que se producen en el país. Es decir, que el entorno en el que se desarrolla la vida de los autores es la fuente de inspiración para la producción literaria de los mismos.

El presente estudio se acerca a la narrativa en cuestión desde ópticas que corresponden con tres rasgos fundamentales: el discurso, la temática y la ideología. El análisis de cada una de estas áreas de enfoque saca a la luz características que confirman lo que constituye la tesis de este trabajo: el desmoronamiento del ideal revolucionario del Hombre Nuevo. Los textos escogidos producen la evidencia necesaria de que el discurso, la temática, y la ideología que en ellos se manifiestan difieren de las pautas instauradas por la revolución cubana y revelan la caída del ideal del Hombre Nuevo, paradigma propuesto por Ernesto Guevara como prototipo del buen revolucionario. Cada uno de los textos analizados constituye una prueba fehaciente de que el esfuerzo por crear un modelo de ciudadano partiendo de un arquetipo determinado que obvie la individualidad y libre albedrío es infructuoso.

El análisis discursivo en los textos de Pedro Juan Gutiérrez, Jorge Alberto Aguiar y Ángel Santiesteban indica una evidente tendencia hacia una forma de expresión 
tremendista y sucio-realista que mucho dista del discurso revolucionario cubano, permitido por el gobierno y respetado por la intelectualidad desde el triunfo de la revolución hasta comienzos de la década del noventa. El discurso se convierte, por lo tanto, en un elemento transgresor y contracultural. A través del uso del argot popular con todos los matices pertinentes, como las obscenidades, las descripciones repulsivas, la imitación del lenguaje hablado, el descomedimiento en la narración de escenas sexuales, entre otros rasgos, los autores logran fotografiar un entorno tan grotesco como el lenguaje que lo describe. Y es en ese intento de plasmar la realidad tal cual es que el lenguaje de Gutiérrez, Aguiar y Santiesteban se convierte en un acto de desobediencia que hasta el momento había sido rigurosamente castigado por las autoridades culturales de la isla.

Si bien el discurso literario del Período Especial subvierte las pautas establecidas, no es éste el único elemento subversivo que caracteriza la narrativa de este momento histórico puesto que a nivel temático también se observan innegables elementos transgresores, como lo es la recurrencia de temas como el hambre, el exilio y la nostalgia. Estos temas constituyen una suerte de hilván entre los textos de Daína Chaviano, Zoé Valdés y Abilio Estévez debido a la función metafórica que desempeñan, pues tanto el hambre como el exilio y la nostalgia son una metáfora a través de la cual se logra la conceptualización del gran tema de la narrativa cubana del Periodo Especial que es la carencia. ¿Hasta que punto representa la discusión del tema de la carencia un elemento transgresor en la narrativa revolucionaria cubana? Para responder a tal interrogante es necesario recordar que el Hombre Nuevo en su forma más pura es un individuo que cree plenamente en la misión mesiánica de la revolución y que lucha estoicamente por alcanzar los ideales propuestos por la misma. Por lo tanto, en la vida del Hombre Nuevo 
sólo hay espacio para la esperanza de forjar un futuro socialista, de manera que no hay cabida para la carencia, porque nada le hace falta al Hombre Nuevo mientras su principal prioridad sea la entrega total e incondicional a la causa revolucionaria. No obstante, como se observa en estos textos, la carencia que experimenta el héroe literario del Período Especial se hace evidente a través de una búsqueda que va desde lo más elemental en el ámbito material hasta lo más sublime en el orden espiritual. El hecho de que en un texto literario dado se presenten personajes que lo han perdido todo, incluso su razón de ser, es sin duda un acto de rebeldía del escritor frente a un entorno que, por una parte lo oprime y por otra lo margina, pero que inevitablemente lo inspira.

Mientras que los rasgos discursivos y la temática constituyen claros elementos transgresores, éstos funcionan en cierto sentido como una suerte de alegoría, pues el lenguaje crudo y descarnado y las temáticas que hasta el momento eran tabú en la literatura revolucionaria reflejan las transformaciones que se producen a nivel ideológico. En los textos de Leonardo Padura, Jesús Díaz y Abel Prieto se observan varias facetas de tales mutaciones ideológicas, pues en ellos se pone de manifiesto de una forma u otra, toda una filosofía del cuestionamiento. Por una parte, Padura lleva a cabo un cuestionamiento abierto de la historia oficial que incorpora elementos socio-políticos y literarios. Por otra parte están los textos de Díaz y Prieto en los que se analiza el proyecto revolucionario cubano desde una óptica crítica que mucho dista de la aproximación benevolente y neutral permitida hasta el momento. Ambos autores establecen una relación recíproca entre el pueblo y la revolución donde el uno ha contribuido consistentemente a la degradación del otro. Recuérdese que el cuestionamiento no forma 
parte del paradigma de comportamiento del Hombre Nuevo, pues él está dispuesto a asumir y defender hasta la muerte los ideales propuestos por la revolución.

La lectura de los textos que ocupan este estudio revela la caída del ideal del Hombre Nuevo propuesto por el proyecto revolucionario cubano como modelo ideológico y de acción. No obstante, con esta revelación surge también una interrogante que ha de explorarse, si bien una respuesta concreta al respecto parece altamente improbable: ¿Qué ha quedado en el sitio que una vez ocupara el ideal del Hombre Nuevo? Tal vez sería acertado establecer una suerte de paralelo entre la caída de este ideal y la muerte de Dios propuesta por Nietzsche y anunciada por su personaje Zarathustra. Dicho paralelo es plausible en la medida en que el individuo asuma la existencia de Dios como un ideal que llega a convertirse en su razón de ser, en la esperanza en un futuro muy diferente a su entorno inmediato. Si Dios es ese tipo de ideal, su desaparición provocaría un vacío que ha de manifestarse en diversas formas.

Cuando Zarathustra, luego de pasar un largo tiempo aislado del mundo, regresa a anunciar la muerte de Dios, pretende además mostrarle al hombre "el sentido de su existencia" (Nietzsche 18). Y por eso habla de dos personajes conceptuales que son el último hombre y el superhombre, tipos diametralmente opuestos en cuanto a sus reacciones frente al vacío que deja el desmoronamiento de un ideal dado, frente al nuevo carácter absurdo de la vida. Según afirma Eugen Fink, "Nietzsche se decide con pasión. Él enseña el superhombre y muestra la índole profundamente despreciable del último hombre" $(80)^{1}$. ¿Sería acaso factible mirar al personaje conceptual de la narrativa cubana

\footnotetext{
${ }^{1}$ Zarathustra describe ambos modelos de la siguiente manera: "El Superhombre es el sentido de la tierra. Que vuestra voluntad diga: ¡Sea el Superhombre el sentido de la tierra!” (10). "Hay que hablarles incluso del más despreciable de entre ellos: el último hombre" (15).
} 
del Período Especial a través del modelo propuesto por Nietzsche? La respuesta está en el fenómeno que se produce frente a la muerte del ideal: el nihilismo, en sus diversas manifestaciones ${ }^{2}$. El superhombre, como es de esperarse, se supera a través de su voluntad de poder y trasciende cualquier manifestación de nihilismo. Por su parte el último hombre es, como explica Heidegger, "aquel que ya no es capaz de ver más allá de sí mismo y de ascender antes que nada por encima de sí mismo hasta el ámbito de su misión para hacerse cargo de la misma" (3). Y en eso radica el carácter despreciable del último hombre ${ }^{3}$.

Es posible realizar un acercamiento retrospectivo a los textos que ocupan este estudio con miras a dilucidar la correspondencia, si acaso la hay, entre los personajes que pululan la narrativa cubana del Periodo Especial y los personajes conceptuales propuestos por Nietzsche. A simple vista, podría decirse que en efecto, el personaje típico de estos textos es nihilista. Pero si recordamos el argumento de Nimrod Aloni de que "something is nihilistic if it promotes submissiveness, conformity, mediocrity, passivity and impersonal behavior; if it discourages the development of the kind of individuals and personal dispositions through which life grows in meaning and attains growth" (61), y si se tienen en cuenta las diferentes facetas del nihilismo, entonces el asunto adquiere una mayor complejidad. Por lo tanto, es factible afirmar que el nihilismo es un problema que se manifiesta en sentido general en todos los textos estudiados, pero a la hora de analizar

\footnotetext{
${ }^{2}$ En su estudio sobre la filosofía de Nietzsche, Eugen Fink discute varias etapas del nihilismo. En una se produce el pesimismo de la debilidad o la decadencia, en la cual el individuo dice no a la vida a causa de la crueldad de ésta. En otra se produce el pesimismo de la fortaleza, que no admite ninguna falsificación idealista de la vida. Y por último se produce el nihilismo extremo en el cual no hay verdad alguna, ni naturaleza absoluta y donde se niega la forma divina de pensar (184).

${ }^{3}$ Benoît Goetz explica que "le dernier homme est la figure la plus stable de l'humanité, celle qui est parvenue à paralyser tout devenir. Il a réussit à immobiliser tout processus, à inhibiter toute lutte, à couper tous les ponts. En lui rien ne se passe" (6).
} 
a los personajes, es preciso hacerlo teniendo en cuenta cómo superan, o si pretenden siquiera superar la situación nihilista en la que se encuentran. Por ende, la interrogante no debe ser si existe el nihilismo en la vida de estos personajes (lo cual es evidente), sino en qué tipo de hombres se convierten, frente a la nada que los agobia, frente al carácter absurdo de sus vidas.

Es importante considerar, sin embargo, la gran diferencia que existe entre el carácter de los personajes que protagonizan los textos estudiados y el creador en sí. Debe notarse que el mero acto de la creación literaria que se discute en este trabajo, la existencia de textos que subvierten las pautas establecidas en cuanto a lenguaje, temáticas e ideología representa un claro acto de rebelión y de inconformidad y sobre todo de individualidad, es decir, rasgos que divergen del nihilismo. ¿Es posible afirmar, entonces, que la narrativa cubana del Período Especial es nihilista? La respuesta más sensata parece ser que la creación literaria no es nihilista, pero que la realidad que se plasma en ella y sus personajes sí lo son.

Si se tomaran como ejemplo algunos de los personajes que se han analizado previamente, se puede concluir que individuos como Rey, Magda, JAAD, Johnny P., la Puerca, la Perra, el Gordo, el Rojo y Una podrían ser considerados como realizaciones del último hombre, aquel que tendría que guardar silencio frente a Zarathustra cuando dice: "El hombre es algo que debe ser superado. ¿Quién de vosotros ha hecho algo para superarle?" (Nietzsche10). Para algunos de ellos la muerte violenta y prematura es ya un claro indicio, y para otros el abismo existencial es tan profundo que la esperanza de superación es casi nula. No obstante, la mera existencia de otro tipo de personajes como Claudia, Gilberto, Rubén, Marcela, Don Fuco, Victorio, Salma, Freddy Mamoncillo, 
Marco Aurelio, Fernando Terry, Miguel Ángel y Pedro Juan no indica que en ellos se manifieste lo contrario; es decir, el superhombre. Si bien en estos personajes se vislumbra una insipiente voluntad de poder, un leve intento de trascender que no se observa en los demás, sería prematuro siquiera sugerir un acercamiento al modelo nietzscheano del superhombre. Esto demuestra cuán complejos son los matices del asunto, pues es imposible categorizar a los seres humanos partiendo de dos modelos conceptuales.

Ya se ha dicho que frente al fracaso del proyecto revolucionario se produce un inevitable desencanto. Por lo tanto, tal vez debería prestársele atención a un concepto que facilitaría la comprensión de aquello que ha venido a remplazar lo que una vez fue el ideal del Hombre Nuevo: el héroe absurdo. Este concepto que Albert Camus presenta en Le mythe de Sisyphe constituye una categoría cuyas características y nuances, reconocen la complejidad y la individualidad del ser humano. Este héroe reconoce el carácter absurdo de su existencia (lo cual puede suceder, por ejemplo, frente a la caída de un ideal, cualquiera que éste sea). Camus explica que "le sentiment de l'absurdité au detour de n'importe quelle rue peut frapper à la face de n'importe quel homme" (24). Visto desde esa óptica, cabe concluir que cualquier ser humano, en cualquier momento de su vida, puede convertirse en un héroe absurdo. Sin embargo, para Camus el problema no está en el hecho de que el hombre descubra el carácter absurdo de su existencia, sino de lo que hará frente a tal comprensión: "À partir du moment où elle est reconnue, l'absurdité est une passion, la plus déchirante de toutes. Mais savoir si l'on peut vivre avec ses passions, savoir si l'on peut accepter leur loi profonde qui est de brûler le coeur [...] voilà la question" (38). El descubrimiento de una existencia absurda no implica que 
el individuo caiga en el nihilismo extremo, y por eso Camus afirma: "Je tire ainsi de l'absurde trois conséquences qui sont ma révolte, ma liberté, et ma passion" (66).

Cuando Albert Camus habla de le héros absurde se basa en la figura de Sísifo por el carácter absurdo del eterno castigo que le han propiciado los dioses. En Sísifo, Camus observa la rebelión, la libertad y la pasión ${ }^{4}$, pues la roca que éste ha de subir a la cima de la montaña, para luego verla caer irremediablemente, se ha convertido en su razón de ser, en $s u$ roca y en la causa de su rebelión contra los dioses. Pero se trata, como afirma Fred Willhoite, de una rebelión que "requires a wholehearted embracing of life, a perpetual struggle against death" (37). Y es que la lucha de Sísifo no podría continuar si él no estuviese verdaderamente aferrado a la vida, por muy absurda que ésta le parezca. En resumen lo que sucede es que el ser humano reconoce que no existe una explicación lógica para la realidad en la que vive, y deja de buscar esa explicación, abandonándose por completo a una existencia sin sentido. En los textos analizados se observa una actitud de desencanto recurrente entre los personajes, y esto se debe a que ellos han llegado a la comprensión de que su entorno carece de sentido. Sin embargo, mientras algunos se abandonan por completo al desaliento, otros optan por rebelarse y cuestionar aunque muchas veces lo hagan en silencio.

Si se concluyese que el ideal del Hombre Nuevo desaparece para sólo dejar en su lugar a la nada, se estaría cometiendo el error de obviar otros derroteros igualmente plausibles. El Hombre Nuevo ha sido remplazado por un nuevo hombre que es una y muchas variantes del héroe absurdo de Camus, uno que busca, sí, pero no mirando al

\footnotetext{
${ }^{4}$ On a compris déjà que Sisyphe est le héros absurde. Il l'est autant par ses passions que par son tourment. Son mépris des dieux, sa haine de la mort et sa pasión pour la vie, lui ont valu ce supplice indicible où tout l'être s'emploie à ne rien achever. C'est le prix qui'il faut payer pour les passions de cette terre" (164)
} 
pasado, sino al presente. Ha dejado de aferrarse a lo que ya no existe, y se conforma con los retazos que le han quedado para con ellos crearse una nueva realidad. Como afirma el escritor francés, “[U]n homme sans espoir et conscient de l'être n'appartient plus à l'avenir" (50). Ya no se trata simplemente del estoico héroe revolucionario, ni del marginado héroe existencialista, ni del último hombre, ni del superhombre. Lo que ha quedado en lugar del Hombre Nuevo es un héroe posrevolucionario que contiene todos estos matices. A fin de cuentas, es un hombre que ha sabido reconocer el carácter absurdo de su tiempo y espacio, pero que de vez en cuando se atreve a alzar la mirada hacia el futuro aunque se tropiece con la desesperanza. Ese héroe posrevolucionario logra trascender las limitaciones empíricas de su entorno para enfrentar los grandes retos existenciales que aún están por llegar. 


\section{Bibliografía}

Aguiar Díaz, Jorge Alberto. Adiós a las almas. La Habana: Editorial Letras Cubanas, 2002

---. "Censura contra poetas y cantantes". Cubanet Independiente. 7 agosto 2006 $<$ http://www.cubanet.org/Cnews/y02/dec02/09a7.htm>.

Alberto, Eliseo. Informe contra mí mismo. Madrid: Alfaguara, 1997.

Alchazidu, Athena. "Generación X: Una modalidad finisecular del tremendismo" Études Romanes de Brmo. 32.23 (2002): 99-108.

Aloni, Nimrod. Beyond Nihilism: Nietzsche's Healing and Edifying Philosophy. Londres: UP of America, 1991.

Angvik, Birger. "La teoría de la novela de Mario Vargas Llosa y su aplicación en la crítica literaria". La narración como exorcismo. Mario Vargas Llosa, obras (1963-2003). Lima: FCE, 2004.

Añel, Armando. "El problema del diversionismo ideológico". Cubanet Independiente. 7 agosto $2006<\mathrm{http}: / /$ www.cubanet.org $>$.

Aparicio Laurencio, Ángel. Introducción. Espejo de paciencia. Por Silvestre de Balboa. Miami: Ediciones Universal, 1970.

Bartlett, Frederic Charles. Remembering: A Study in Experimental and Social Psychology. London: Cambridge UP, 1932.

Béjar, Eduardo C. La textualidad de Reinaldo Arenas: Juegos de la escritura posmoderna. Madrid: Editorial Playor, 1987.

Besada, Juan Lázaro. "Confesiones desde el umbral de los cincuenta". Consenso. 7 agosto $2006<\mathrm{http}: / /$ consenso.org/08/articulos/12_01.shtml $>$.

Boym, Svetlana. The Future of Nostalgia. New York: Basic Books, 2001.

Brewer, Gay. Charles Bukowski. London: Prentice Hall International, 1997.

Buckwalter-Arias, James. "Reinscribing the Aesthetic: Cuban Narrative and Post-Soviet Politics". PMLA. 120.2 (March 2005): 362-73.

Buford, Bill. "Editorial". Granta. 8.8 (1983): 4-5.

Bukowski, Charles. Factotum. New York: Harper Collins, 1975. 
---. Women. New York: Harper Collins, 1978.

Byrne, Jack. "Bukowski's Chinaski: Playing Post Office." The Review of Contemporary Fiction. Ed. John O’Brien. 5.3 (Fall 1985): 43-51.

Cairo, Ana. Heredia entre cubanos y españoles. La Habana: Editorial Oriente, 2003.

Camacho, Jorge. "Los herejes en el convento: La recepción de José Martí en la plástica y la crítica cubana de los años 80 y 90". Espéculo. 7 agosto 2006 $<$ http://ucm.es/info/especulo/numero24/herejes.html $>$.

Camargo, Luis. "Subjetividades de la niñez: una mirada al sur". Psicoanálisis en la Web 19 mayo 2006. <http//www.psiconet.com/camargo/nota7.html>.

Camus, Albert. Le mythe de Sisyphe. Paris: Gallimard, 1942.

Carranza-Valdés, Julio, Luis Gutiérrez Urdaneta y Pedro Monreal González. Cuba: La reestructuración de la economía. La Habana: Editorial de Ciencias Sociales, 1995.

Casal, Lourdes. "La novela en Cuba, 1959-1967: Una introducción". Exilio (1969-1970): 184-217. --.. "The Cuban Novel, 1959-1969: An Annotated Bibilograpy". Abraxas (Otoño 1970): 77-92.

---. "Para Ana Veltfort". Areíto. (Verano de 1976): 52.

Castells, Ricardo. "La novela policíaca en la Cuba del período especial: Pasado perfecto de Leonardo Padura Fuentes". South Eastern Latin Americanist. 43.4 (2000): 2135 .

Cela, Camilo José. La familia de Pascual Duarte. Barcelona: Ediciones Destino, 1972.

Cendrars, Blaise. "Un écrivain américain nous est né". Henry Miller and the Critics. Ed. George Wickes. Carbondale: Southern Illinois UP, 1963.

Clark, Stephen. "El Rey de Centro Habana: Conversación con Pedro Juan Gutiérrez". LiteraturaCubana.com. 24 agosto 2004

$<$ http://www.librusa.com/entrevista7.htm>.

Crabb, Mary Katherine. "The Political Economy of Caudillismo". Cuban Communism 1959-2003. New Brunswick: Transaction Publishers, 2004.

Cuadra, Ángel. "La poesía en el exilio: el tema de lo cubano" Creación y exilio: Memorias del I encuentro internacional con Cuba en la distancia. Madrid: Editorial Hispano Cubana, 2002. 
Cuervo-Hewitt, Julia. Aché, presencia africana: tradiciones yoruba-lucumí en la narrativa cubana. New York: Peter Lang, 1988.

Chango, Daniel. "Exilio e insilio: una mirada de tres décadas desde y hacia San Juan que prolonga su insilio interminable". Diario Libre. 19 mayo 2006. $<\mathrm{http} / / \mathrm{www}$. diariolibre.info/secciones/noticas/nota.php?id=805>.

Chase, Malcolm and Christopher Shaw. "The Dimension of Nostalgia". The Imagined Past: History and Nostalgia. Manchester: Manchester UP, 1989.

Chaviano, Daína. El hombre, la hembra y el hambre. Barcelona: Editorial Planeta, 1998.

Chimal, Alberto y Josefina Pacheco. "La CF cubana vista desde el exterior". Guaicán Literario. 15 febrero 2006. $<$ http://www.cubaliteraria.com/guaican/cronicas/exterior1.html $>$.

Davis, Fred. Yearning for Yesterday: A Sociology of Nostalgia. New York: The Free Press, 1979.

Del Risco, Enrique. "El último exilio o nuevas posibilidades de lo cubano" Creación y exilio: memorias del I encuentro internacional con Cuba en la distancia. Madrid: Editorial Hispano Cubana, 2002.

Desonoes, Edmundo. "Epílogo para intelectuales". Los dispositivos en la flor. Hanover: Ediciones del Norte, 1981. 533-552.

---. Memorias del subdesarrollo. 3ra Edición. México: J. Mortiz, 1980.

---. "No es un prólogo para cubanos". Los dispositivos en la flor. Hanover: Ediciones del Norte, 1981. xv-xxv.

Díaz, Jesús. Las palabras perdidas. Barcelona: Ediciones Destino, 1992.

-.-. "Para una cultura militante". Lecturas de filosofia. La Habana: Instituto del Libro, 1968.

Diez de la Cortina Montemayor, Elena. "El estoicismo". Cibernous. 19 julio 2006 $<\mathrm{http}$ ://www.cibernous.com/autores/seneca/teoria/estoicismo.html $>$.

Dobozy, Tamas. "In the Country of Contradiction the Hypocrite is King: Defining Dirty Realism in Charles Bukowski's Factotum.” Modern Fiction Studies. 47.1 (2001): 43-68. 
Domínguez García, María Isabel. "La juventud cubana en una época de crisis y reestructuración". Cuba: Periodo Especial. Perspectivas. Ed. Mayra Díaz Arango. La Habana: Editorial de Ciencias Sociales, 1998.

Domínguez, Jorge I. "Blaming Itself, Not Himself: Cuba's Political Regime After the Third Party Congress". Socialist Cuba: Past Interpretations and Future Challenges. Ed. Sergio G. Roca. Boulder \& London: Westview Press, 1988.

Donahue, Francis. "Cela and Spanish Tremendismo". Western Humanities Review. 20 (1966): 301-6.

Encyclopedia of American History: Bicentennial Edition. Ed. Richard B. Morris. New York: Harper \& Row Publishers, 1975.

Enrique, Antonio. “Así sí: Una sorprendente novela sobre La Habana”. 25 octubre 2002. $<\mathrm{http}: / /$ dainachaviano.com/criticaantonioenriquespanish.html $>$.

Epple, Juan Armando. "Leonardo Padura Fuentes: Entrevista". Hispamerica: Revista de Literatura 24.71 (Agosto 1995): 49-66.

Espinosa-Domínguez, Carlos. El peregrino en comarca ajena: Panorama crítico de la literatura cubana en el exilio. Boulder: Society of Spanish and Spanish American Studies, 2001.

Estévez, Abilio. Los palacios distantes. Barcelona: Tusquets, 2002.

---. "Sin miedo la vida sería terriblemente aburrida". El cultural. 19 mayo 2006. $<$ http://www.elcultural.es/html/20041209/letras/letras10881.asp>.

Facio, Elisa. "Jineterismo During the Special Period". Global Developmente Studies I. 34 (Winter 1998 - Fall 1999), 57-78.

Facknitz, Mark A. R. "Minimalism." Benet's Reader Encyclopedia of American Literature. Ed. George Perkins, Barbara Perkins, Phillip Leininger. New York: Haper Collins, 1991. 714-15.

Fernández, Damián J. Cuba and The Politics of Passion. Austin: University of Texas Press, 2000.

---. "The Politics of Youth in Cuba: Patterns, Dynamics, and Future Challenges".

Appendix B. Cuba After Castro: Legacies, Challenges and Impediments. Eds. Edward González y Kevin F. McCarthy. Arlington VA: RAND Corporation, 2004. 
Fernández-Olmos, Margarite \& Elisabeth Paravisini-Gebert. El placer de la palabra: literatura erótica femenina de América Latina. México: Editorial Planeta, 1991.

Fink, Eugen. La filosofia de Nietzsche. Trad. Andrés Sánchez Pascual. Madrid: Alianza Editorial, 1976.

Florián, Víctor. Diccionario de filosofia. Bogotá: Panamericana Editorial, 2002.

Fornet, Ambrosio. "La diáspora como tema". La jiribilla. 12 mayo 2005. $<\mathrm{http} /$ /www.lajiribilla.cu/paraimprimir/nro1/0009_imp.html>.

Fowler, Víctor. Rupturas y homenajes. La Habana: Ediciones Unión, 1998.

Gaceta de Cuba. "Declaración del Primer Congreso Nacional de Educación y Cultura". 90-91 (Marzo-abril 1971): 10.

Gahete-Jurado, Manuel. "Erótica y mística: en el ápex de la paradoja." El cortejo de Afrodita: ensayos sobre literatura hispánica y erotismo. Málaga: Analecta Malacitana, 1997.

Garcerán de Vall, Julio. Heredia y la libertad. Miami: Ediciones Universal, 1978.

García Luis, Julio. Revolución cubana: 40 grandes momentos. La Habana: Editorial Política, 2000.

García-Posada, Miguel. "El espejo de la crítica: Abilio Estévez y Los palacios distantes" Revista de Cultura Lateral. 19 mayo 2006.

<http://www.lateral_ed.es/revista/espejp/099abilioestevez.htm>.

García Reyes, Miguel y Ma. Guadalupe López de Llergo. Cuba después de la era soviética. México, D.F: El Colegio de México, 1994.

Garrandés, Alberto. "La humedad del discurso (erotismo y sexualidad en la narrativa cubana del siglo XX)". Síntomas: Ensayos críticos. La Habana: Ediciones Unión, 1999.

Goetz, Benoît. 'Le 'dernier homme' de Nietzsche: Quelques aspects d'un 'personnage conceptue"'. Le Portique: Revue de philosophie et de sciences humaines. 19 enero 2007. <http://leportique.revuew.org>.

Goldmann, Lucien. "Introducción a los primeros escritos de Georg Lukács". Teoría de la novela. Tr. Juan José Sebreli. Barcelona: Edhasa, 1971. 171-203.

González, Edward y Kevin F. McCarthy. Cuba After Castro: Legacies, Challenges, and Impediments. Arlington VA: RAND Corporation, 2004. 
González, Edward. "The Legacies of Fidelismo and Totalitarianism". Appendix A. Cuba After Castro: Legacies, Challenges and Impediments. Arlington VA: RAND Corporation, 2004.

González-Abellás, Miguel. "El problema del yo: Autor y narrador en a ficción cubana reciente". Espéculo. 29. 24 mayo de 2005.

$<$ http://www.ucm.es/info/especulo/numero29/probleyo.html>.

---. "La figura de la mulata en el fin del milenio: Trilogía sucia de La Habana". Hispanic Journal. 22.1 (Spring 2001): 251-62.

González-Acosta, Alejandro. "Heredia: Iniciador de caminos". Encuentro de la cultura cubana 26 (2002): 293-94.

González-Ortega, Nelson. "La novela latinoamericana de fines del siglo XX: 1967-1999. Hacia una tipología de sus discursos". Modern Sprak. 93.2 (1999): 203-8.

Guevara, Ernesto. "El socialismo y el hombre en Cuba". El socialismo y el hombre nuevo. Ed. José Aricó. México D.F: Siglo XXI, 1977. 3-18.

Gullón, Germán. "Contextos ideológicos y forma narrativa en La familia de Pascual Duarte: En busca de una perspectiva lectoral". Hispania. 68.1 (1985): 1-8.

Gutiérrez Coto, Amauri Francisco. "Más que fábulas el pecado de los falsos mitos: Sigue el debate... Respuesta al poeta Antonio José Ponte". Revista Vitral 69. XII. (Septiembre-octubre 2005): <http://www.vitral.org/vitral 69/lectl.htm >.

Gutiérrez, José Ismael. "Reinaldo Arenas: exilios reales y ficcionales". Creación y exilio: Memorias del I encuentro internacional con Cuba en la distancia. Madrid: Editorial Hispano Cubana, 2002.

Gutiérrez, Pedro Juan. El Rey de La Habana. Barcelona: Anagrama, 1999.

---. Trilogía Sucia de La Habana. Barcelona: Anagrama, 1998.

Heidegger, Martin. "La frase de Nietzsche 'Dios ha muerto"'. Caminos de bosque, Trad. Helena Cortés y Arturo Leyte. Madrid: Alianza, 1995. 190-240.

---. “¿Qué significa pensar?” Nietzsche en castellano. Trad. H. Kahmemam. 9 enero 2007 $<$ http://www.nietzscheana.com.ar>.

Hernández, David. "Literatura cubana: Sobre animales tropicales". La Opinión. 18 de noviembre de 2001. <http://www.cubanet.org/Cnews/y01/nov01/19o8.htm>. 
Hernández, Luis Arturo. "Sexo, drogas y malecón”. Literatura Luke. 13 junio de 2005. $<$ http:/www.espacioluke.com/marzo2001/quintacolum.html $>$.

Howe, Linda S. Transgression and Conformity: Cuban Writers and Artists after the Revolution. Madison: The University of Wisconsin Press, 2004.

Ilie, Paul. La novelística de Camilo José Cela. Madrid: Editorial Gredos, 1963.

Ilie, Paul. Literature and Inner Exile. Baltimore: The John Hopkins UP, 1980.

Jerez-Farrán, Carlos. "Pascual Duarte y la susceptibilidad viril”. Hispanofilia. 32.2 (1995): 47-63.

Kessler, Stephen. "Notes on A Dirty Old Man." The Review of Contemporary Fiction. Ed. John O’Brien. 5.3(Fall 1985): 60-63.

Kirk, John M. Prólogo. La cultura y la revolución cubana: Conversaciones en La Habana. San Juan: Editorial Plaza Mayor, 1999. 11-25.

Kirsner, Robert. "Trauma and Tenderness in the novels and travels of Camilo José Cela". The Review of Contemporary Fiction. 4:3 (1984): 51-63.

Krell, David Farell. Of Memory, Reminiscence, and Writing. Indianápolis: Indiana UP, 1990.

Kristeva, Julia. Pouvoirs de l'horreur. Paris: Editions du Soleil, 1980.

Kronic, John W. "Encerramiento y apertura: Pascual Duarte y su texto". Anales de Literatura Española. 6 (1988): 309-23.

Laponte, Felipe A. "La violencia en la obra de Cela: Entre el poder y la resistencia". $A I H$ Actas Irvine. Ed. Juan Villegas. University of California, 1994.

Leal, Luis y Rodolfo J. Cortina. Prólogo. Jicoténcal. Por Félix Varela y Morales. Houston: Arte Público Press, 1995. (XXV)

Lezama-Lima, José. "Universalidad del roce”. Fragmentos a su imán. México D.F: Biblioteca Era, 1978. 107-108

Lowenfels, Walter. "A Note on Tropic of Cancer, Paris, 1931." Henry Miller and the Critics. Ed. George Wickes. Carbondale: Southern Illinois UP, 1963.

Lowenthal, David. "Nostalgia Tells It Like It Wasn't". The Imagined Past: History and Nostalgia. Christopher Shaw and Malcolm Chase Eds. Manchester: Manchester UP, 1989. 18-32. 
Ludmer, Josefina. "Ficciones cubanas de los últimos años: el problema de la literatura política". Cuba: un siglo de literatura (1902-2002). Eds. Anke Birkenmaier y Roberto González Echevarría. Madrid: Editorial Colibrí, 2002.

Lukács, Georg. Teoría de la novela. Tr. Juan José Sebreli. Barcelona: Edhasa, 1971.

Machover, Jacobo. "Los libros de La Habana en ruinas". Red Literaria. 19 mayo de 2006.

Marín-Minguillón, Adolfo. "La familia de Pascual Duarte y el efecto esquizo". Critical Essays on The Literature of Spain and Spanish America. Eds. Luis González del Valle y Julio Baenas. Boulder: Soc. of Spanish and Spanish American Studies, 1991.

Marty-Clark, Miriam. "Contemporary Short Fiction and the Postmodern Condition". Studies in Short Fiction. 32.2 (1995): 147-60.

Menton, Seymour. Caminata por la narrativa latinoamericana. Veracruz: Editorial UV, 2002.

---. La narrativa de la Revolución cubana. Madrid: Playor. 1978.

Mesa-Lago, Carmelo. Economía y bienestar social en Cuba a comienzos del siglo XXI. Madrid: Editorial Colibrí, 2003.

Miller, Henry. Henry Miller on Writing. Ed. Thomas H.Moore. New York: New Directions, 1964.

Mullen, Bill. "A Subtle Spectacle: Televisual Culture in the Short Stories of Raymond Carver”. Critique. 39.2 (1998): 112.

Negrín, María Luisa. El círculo del exilio y la enajenación en la obra de Reinaldo Arenas. Lewinston: The Edwin Press, 2000.

Nietzsche, Friedrich. Así habló Zarathustra. Tr. J.C. García Borrón. México D.F. Editorial Origen, 1983.

Nogueras, Luis Rogelio. "Joy: Algo más que un perfume". La gaceta de Cuba. 181 (Agosto 1979): 13-15.

Noroña, Juan Pablo. "Reseña bibliográfica de la CF cubana". Guaicán Literario. 15 febrero de 2006.

$<$ http://www.cubaliteraria.com/guaican/Resena_bibliográfica.html $>$. 
Obejas, Achy. "From Havana with Love: A New Generation faces Cuba's Dark Reality". Voice Literary Supplement. 20 julio 2006 $<$ http://www..villagevoice.com/specials/vls/172/obejas.shtml $>$.

Olivares, Mónica. “The Censorship of Literary Narrative in Franco's Spain: an Historical Approach". Culture, Democracy and Dictatorship. 2 julio 2006 $<$ http://www.cliohres.net/books/2/07Olivares.pdf $>$.

Ortega y Gasset José. Meditaciones del Quijote. 4 abril de 2006. $<$ http://www.circunstancia.com>.

Ortega, Mercedes. "La sociología de la literatura: Estudio de las letras desde la perspectiva de la cultura". Espéculo: Revista de estudios literarios. 10 noviembre de 2006. <http://www.ucm.es/info/especulo/numero29/sociolit.html>.

Otero, Lisandro "Notas sobre la funcionalidad de la cultura". Casa de las Américas, 12:68 (Septiembre-octubre 1971): 94.

Padilla, Heberto. "Más allá de nuestros antagonismos". Bipolaridad de la cultura cubana. Ed. René Vázquez Díaz. Estocolmo: The Olof Palme International Center, 1994.

Padura Fuentes, Leonardo y John M. Kirk. "Antón Arrufat: Un escritor al que le sigue latiendo el corazón". La cultura y la revolución cubana: Conversaciones en La Habana. San Juan: Editorial Plaza Mayor, 1999. 53-89

Padura, Fuentes, Leonardo. José María Heredia: La patria y la vida. La Habana: Ediciones Unión, 2003.

---. La novela de mi vida. Barcelona: Tusquets, 2002.

---. "Vivir en Cuba, crear en Cuba: riesgo y desafío". La cultura y la revolución cubana: Conversaciones en La Habana. San Juan: Editorial Plaza Mayor, 1999. 321-332

Parkin, John. Henry Miller, The Modern Rabelais. Lewiston: The Edwin Mellen Press, 1990.

Pérez-Firmat, Gustavo. Cincuenta lecciones de exilio y desexilio. Miami: Ediciones Universal, 2000.

Phaf, Ineke. Novelando La Habana: tratados de crítica literaria. Madrid: Editorial Orígenes, 1990.

Ponte, Antonio José. El libro perdido de los origenistas. México D.F: Editorial Aldus, 2002. 
Prieto, Abel. El vuelo del gato. Barcelona: Ediciones B., 2000.

Prieto-Osorno, Alexander. "Literatura latinoamericana de cajón". Ómnibus Revista Cultural. 15 noviembre de 2004. <www.omni-bus.com/n0/modasliteratura.html>.

Rama, Ángel. "El boom en perspectiva". La novela en América Latina: Panoramas 19201980. Bogotá: Instituto Colombiano de Cultura, 1982.

Raskin, Jonah. American Scream: Allan Ginsberg's Howl and the Making of the Beat Generation. Berkeley: University of California Press, 2004.

Rebein, Robert. Hicks, Tribes \& Dirty Realists. Lexington: University Press of Kentucky, 2001.

Ribas, Armando P. El fin de la idiotez y la muerte del hombre nuevo. Miami: Ediciones Universal, 2004.

Ritivoi, Andrea Deciu. Yesterday's Self: Nostalgia and The Immigrant Identiy. Lanham: Rowman \& Littlefield Publisher, 2002.

Rivas, Mercedes. Literatura y esclavitud en la novela cubana del siglo XLX. Sevilla: Escuela de Estudios Hispano-Americanos, 1990.

Rivero, Eliana. "Lourdes Casal o la experiencia del biculturismo". La jiribilla. 15 junio de 2005. <http://wwwlajiribilla.cu/2005/n237_11_15.html>.

Rodríguez, Genovés, Fernando. "Literatura y territorio moral: Razones para la ética". Ensayos de ética autónoma y de humanismo racional. Valencia: Ediciones Alfons El magnànim-IVEI, 1996. 95-103.

Rojas, Rafael. "El campo roturado: Políticas intelectuales de la narrativa de fin de siglo". Revista Hispano Cubana. 12 (2002): 41-50.

Rojas, Rafael. La politica del adiós. Miami: Ediciones Universal, 2002.

---. Tumbas sin sosiego: Revolución, disidencia y exilio del intelectual cubano. Barcelona: Anagrama, 2006.

Salcedo, Jorge. "Lo extraño todo". Naufragio y sedición en la isla de Juana. Madrid: Betania, 2001.

Sánchez, José Miguel. "Marcianos en el platanar de Bartolo: Análisis de la historia y perspectivas de la CF en Cuba". StarDust. 15 febrero 2006.

$<$ htp://www.stardustcf.com>. 
Sánchez, Yvette. "Esta isla se vende". Todas las islas la isla: Nuevas y novísimas tendencias en la literatura y cultura de Cuba. Ed. Janett Reinstädler y Otimar Ette. Madrid: Vervuet-Iberoamericana, 2000. 163-176

Santana, Cintia Mariela. Influence in Translation: Dirty Realism and the Spanish Novel and Short Story (1985-2000). Diss. Harvard University, 2004. UMI 2004 Microform 3149593.

Santiesteban, Ángel. Los hijos que nadie quiso. La Habana: Editorial Letras Cubanas, 2001.

Sartre, Jean Paul. L'être et le néant: Essai d'ontologie phenomenologique. Paris: Gallimard, 1943.

Schulman, Ivan A. Introducción. Autobiografia de un esclavo. Por Juan Francisco Manzano. Traducción de Evelyn Picon Garfield. Detroit: Wayne State UP, 1996.

Shakespeare, J.C. "Ashcan Rantings and Kind King Lights of Mind: Why the Beat Still Matter." Culture Crash. 26 julio de 2005. $<$ http://www.altx.com/io/beatgeneration.html >.

Silverman, Hugh J. Philosophy and Desire. Introducción (1-13) New York: Routledge, 2000 .

Smith, Julian. "Charles Bukowski and the Avant-Garde". The Review of Contemporay Fiction. Ed. John O’Brien. 5.3 (Fall 1985): 56-59.

Sodowsky, Roland. "The Minimalist Short Story: Its Definition, Writers, and (Small) Heyday". Studies in Short Fiction. 33.4 (1996): 529.

Stephenson. Gregory. The Daybreak Boys: Essays on the Literature of the Beat Generation. Carbondale: Southern Illinois U.P., 1990.

Tabares, Sahily. "Diálogo con Abel Prieto". Revista Bohemia 3 (Agosto 2002): $<$ http://www.cubaminrex.cu/Mirar_Cuba/Entrevistas/entrevistas_dialogo $\% 20$ con $\% 20$ abel\%>

Tavor Bannet, Eve. "Georg Lukács". The John Hopkins Guide to Literary Theory and Criticism. Ed. Michael Groden y Martin Kreiswirth. Baltimore \& Londres: The John Hopkins U P, 1994.

Todorov, Tzvetan. On Human Diversity: Nationalism, Racism and Exoticism in French 
Unamuno, Miguel de. Del sentimiento trágico de la vida. 2 junio 2006. $<$ http://bibliotecas.reduaz.mx/libros-e/libros_de_Miguel_de UnamunoDel_Sentimiento_Tragico_de_la_Vida.pdf $>$.

Valdés y de la Torre, Emilio, comp. Antologia herediana. La Habana: Consejo Corporativo de Educación Sanidad y Beneficencia, 1939.

Valdés, Armando. La escritura de la Isla: Notas sobre la narrativa cubana". Revista Hispano Cubana. 20 octubre $2006<\mathrm{http}$ ://www.hispanocubana.org >.

Valdés, Zoé. Café Nostalgia. Barcelona: Editorial Planeta, 1997.

Valle, Manuel. "Pascual Duarte: ejemplo de familias". Laberinto. 21 octubre 2004. $<$ http://www.laberinto.uma.es/articulosinpublicar/valle.htm>.

Vázquez Díaz, René. "Crítica de la literatura de compromiso: la cuentística de Manuel Cofiño". Encuentro. 1 (Verano 1996): 107-12.

---. Prólogo. Bipolaridad de la cultura cubana. Estocolmo: The Olof Palme International Center, 1994. 7-17.

Willhoite, Fred H. Beyond Nihilism: Albert Camus's Contribution to Political Thought. Baton Rouge: Louisiana State UP, 1968.

Yusti, Carlos. "Bukowski, la litertura de chatarra". Enfocarte: Revista de arte y literatura. 22 junio de 2005. <http://www.enfocarte.com/1.3/opinion.html>.

Zamora-Vicente, Alonso. Camilo José Cela: Acercamiento a un escritor. Madrid: Editorial Gredos, 1962. 
SONIA BEHAR

November 26, 1967

1992

1994

1992-1994

1995-2004

1997-2004

2004-2007
Born, Cuba

Bachelor of Arts

French and Spanish

Florida International University, Miami

Master of Arts

Linguistics

Florida International University, Miami

Teaching Assistant

Florida International University, Miami

English Department

Teacher

Saint Brendan High School, Miami

Saint Thomas University, Miami Gardens

Dual Enrollment Adjunct Instructor

Teaching Assistant

Florida International University, Miami

Department of Modern Languages

\section{PUBLICATIONS AND PRESENTATIONS}

February, 2006. "Perspectivismo y ficción en La novela de mi vida". Paper presented at the Fifth Biennial Florida International University Conference on Spanish and Latin American Cultural Studies. Miami, Florida.

July, 2006. "La figura del mayoral en la novela cubana de la esclavitud". First prize in the CRI writing contest at Florida International University. Miami, Florida. 